\title{
Structure, Conduct and Performance of Maize Markets in Malawi
}

Dennis O. Ochieng, Rosemary Botha, and Bob Baulch 


\section{CONTENTS}

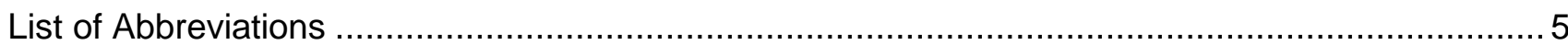

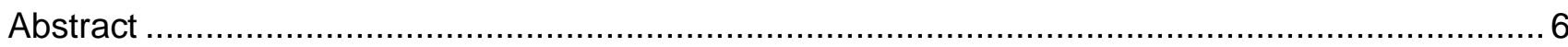

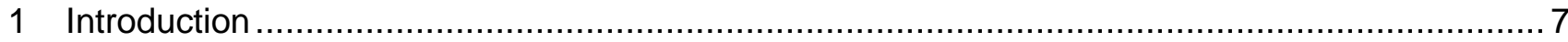

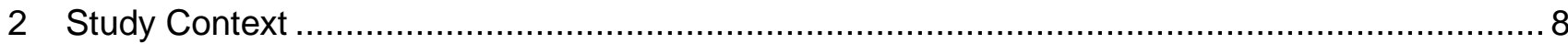

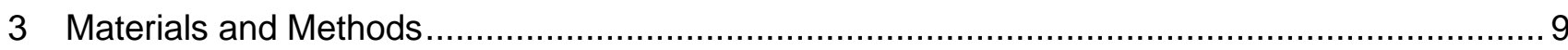

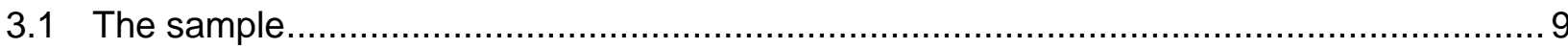

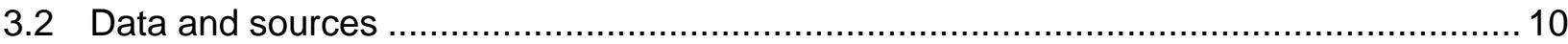

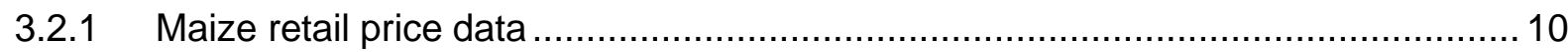

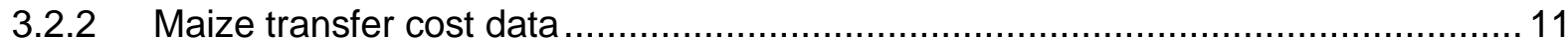

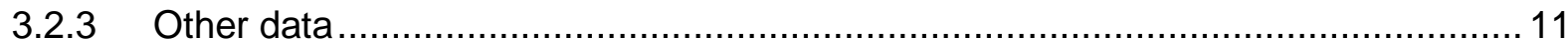

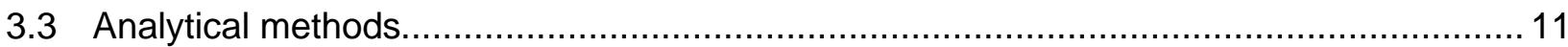

3.3.1 Qualitative analysis ............................................................................ 11

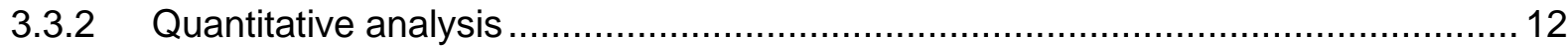

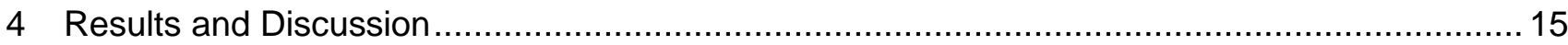

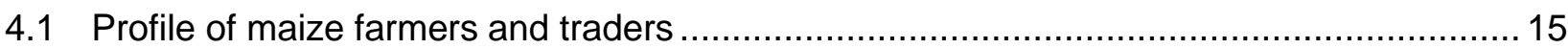

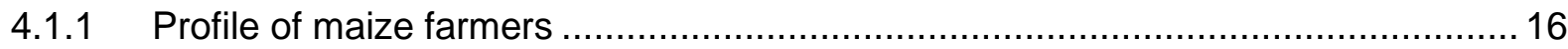

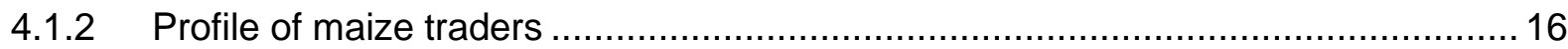

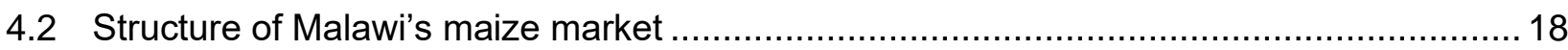

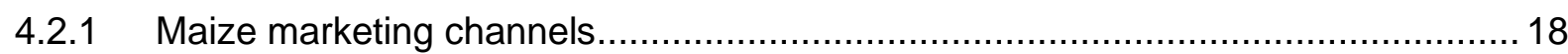

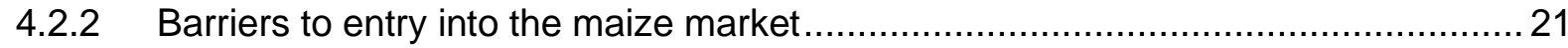

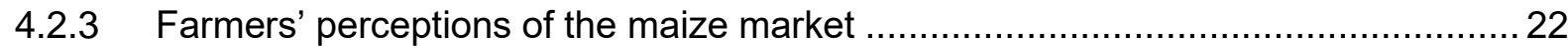

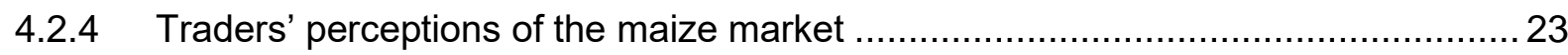

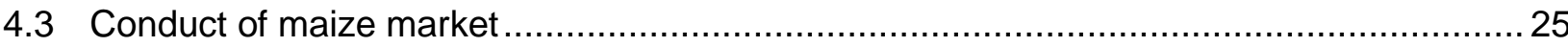

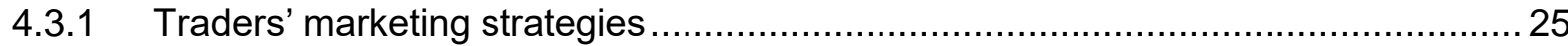

4.3.2 Switches between trader types across seasons .......................................... 27

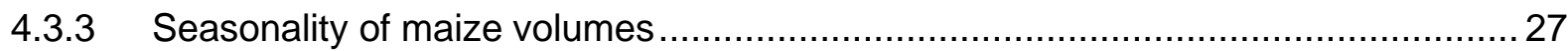

4.3.4 Maize volumes traded through various channels............................................. 28

4.3.5 Inequality in trader sales revenues in the maize market ..................................... 30

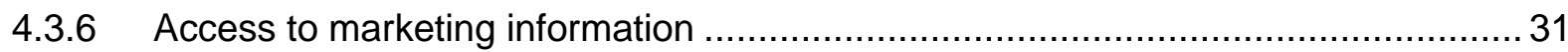

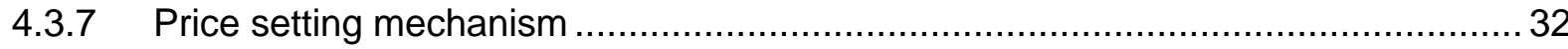

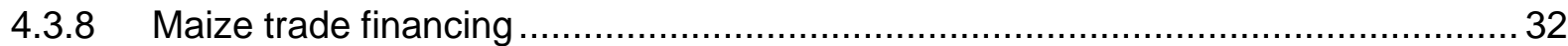




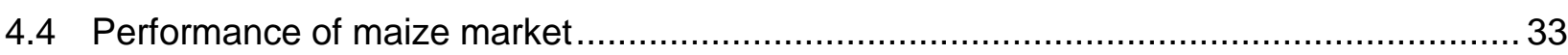

4.4.1 Maize volumes and price dynamics ................................................................ 33

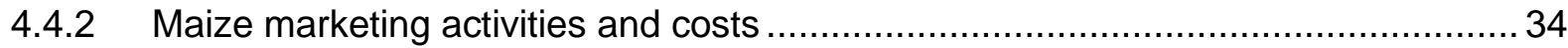

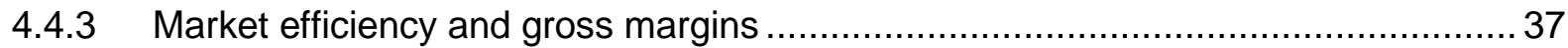

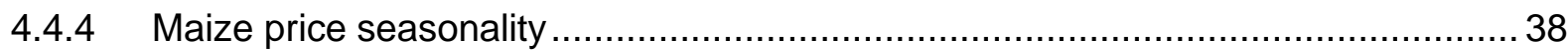

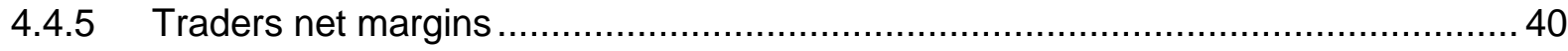

4.4.6 Spatial integration of maize markets ............................................................. 42

4.4.7 Maize price volatility in selected markets........................................................ 44

4.4.8 Maize price volatility in Malawi compared to other countries .............................. 45

4.4.9 Maize price volatility in integrated markets ....................................................... 46

5 Conclusions and Policy Implications ................................................................................ 47

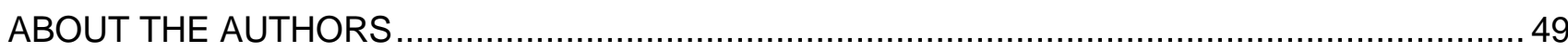

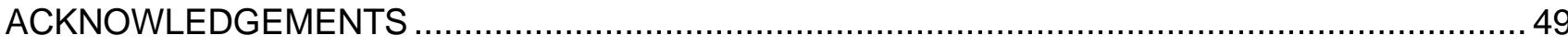

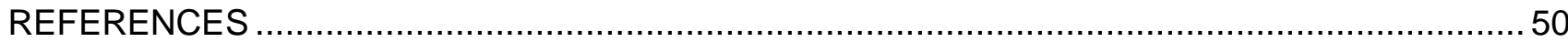

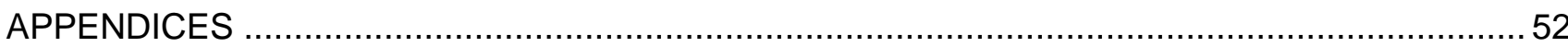

\section{TABLES}

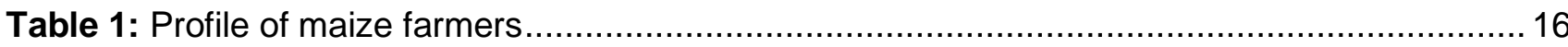

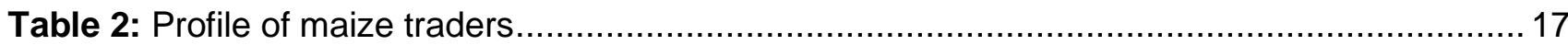

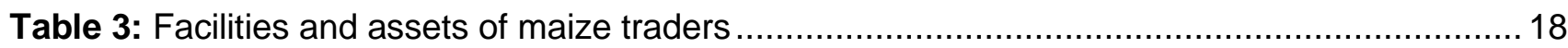

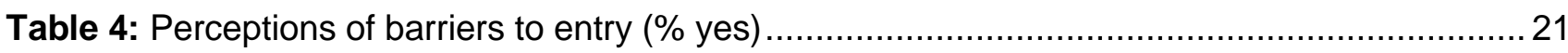

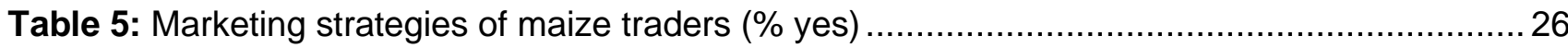

Table 6: Maize purchases and sales in the main marketing and lean season............................29

Table 7: Inequality of sales revenue, measured using Gini coefficients ..................................... 30

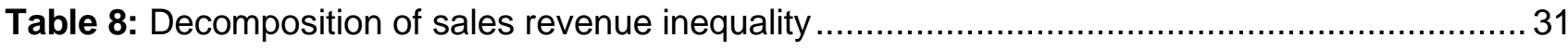

Table 9: Sources of pricing information and their usefulness .................................................... 31

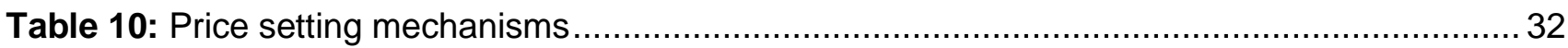

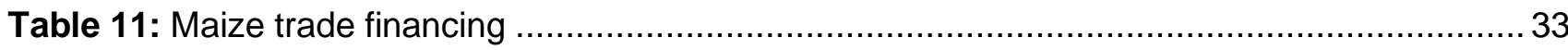

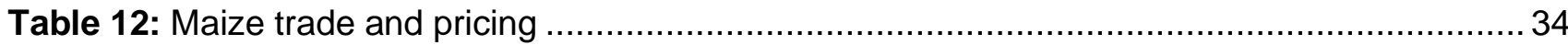

Table 13: Quality improvement activities (\% yes) ................................................................. 35

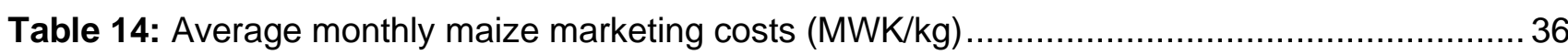

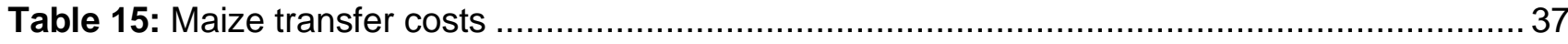


Table 16: Maize trade margins and expenses to revenue ratios. 38

Table 17: Maize price seasonality across Malawi ............................................................. 40

Table 18: Average trader's physical storage costs over an 8-months period, 2018-19 ................ 41

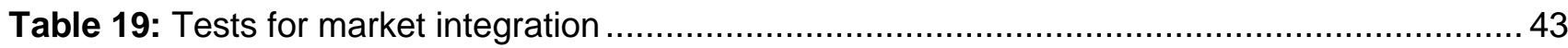

Table 20: Average maize prices and volatility measures in selected markets ............................. 45

Table 21: Price volatility in selected African countries (March 2006-August 2018)..................... 46

Table 22: Variance ratio tests for spatially integrated markets in Malawi ................................... 47

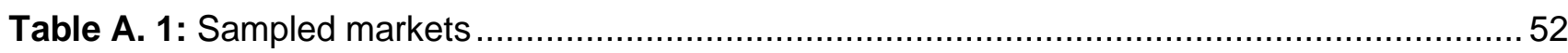

Table A. 2: Test of differences in proportion of purchases and sales across seasons (Mann-Whitney

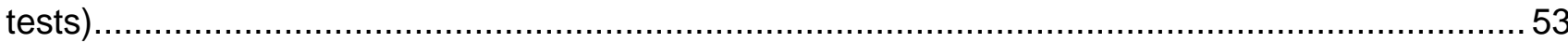

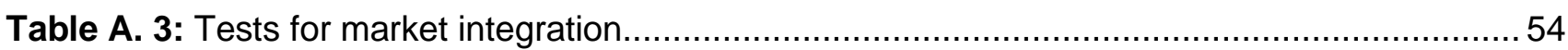

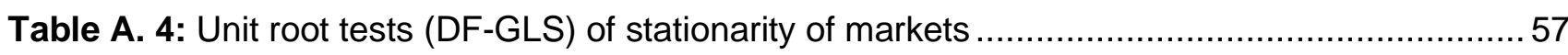

Table A. 5: Bounds test of cointegration of price series ........................................................ 58

\section{FIGURES}

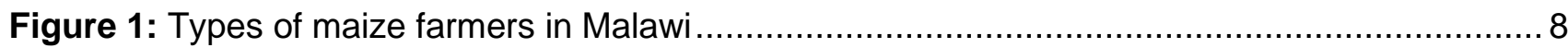

Figure 2: Map of selected markets for the study of spatial market integration in Malawi................ 10

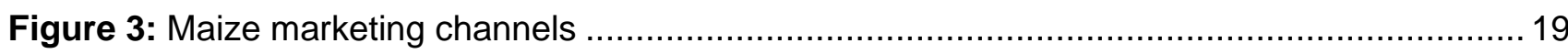

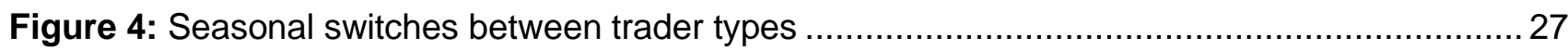

Figure 5: Seasonality of maize volumes traded (MT/month) ............................................... 28

Figure 6: Lorenz curve of sales revenue during the main harvest and lean seasons $2018 \ldots \ldots \ldots . . . .30$

Figure 7: Grand seasonal indices in northern, central and southern region markets .................... 39

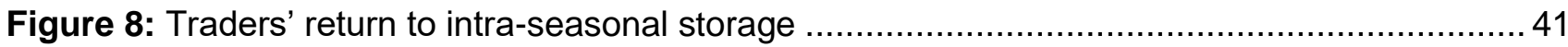

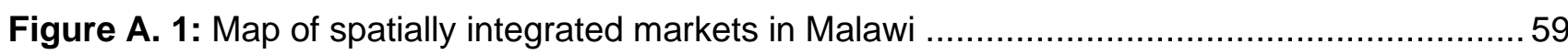

Figure A. 2: Price movements in markets integrated in all regimes, 2017-2018 ....................... 60

Figure A. 3: Price movements in markets integrated in at least one regime, 2017-2018 ............61

\section{CALCULATIONS}

Appendix B. 1: Calculations on traders' return to storage 62 


\section{LIST OF ABBREVIATIONS}

ACE Agricultural Commodity Exchange for Africa

ADMARC Agricultural Development and Marketing Corporation

AHCX Auction Holdings Commodity Exchange

AMIS Agricultural Market Information System

APES Agricultural Production Estimates

EPA Extension Planning Area

FAO Food and Agriculture Organization of the United Nations

FEWS NET Famine Early Warning Systems Network

FGD Focus Group Discussion

FIRP Food Insecurity Response Program

FISP Farm Input Subsidy Program

GoM Government of Malawi

GSI Grand Seasonal Index

HA Hectare

IFPRI International Food Policy Research Institute

KII Key Informant Interview

Kg Kilogram

LoP Law of One Price

MoWAID Ministry of Agriculture, Irrigation and Water Development

MSA Moving Seasonal Average

MT Metric Tons

mVAM Mobile Vulnerability Analysis and Mapping

MWK Malawian Kwacha

NFRA National Food Reserve Agency

OLS Ordinary Least Squares

SCP Structure Conduct and Performance

SGR Strategic Grain Reserve

SHF Smallholder Farmer

SI $\quad$ Seasonal Index

WFP World Food Programme

WRS Warehouse Receipt System 


\section{ABSTRACT}

Seasonal analysis of the structure, conduct, and performance (SCP) of markets for staple crops has received relatively little attention in food policy analysis yet it has important implications for food and nutrition security. This study employs a mixed methods approach to analyze the SCP of maize markets in Malawi in the 2018/19 main harvest and lean seasons. We interviewed 749 traders from 74 markets across 8 districts, held 28 focus group discussions (FGD) with a total of 480 farmers and analyzed daily and weekly price data from 13 regional markets. The structure of maize markets was explored by examining marketing channels, barriers to entry and the competitiveness of different tiers of the marketing chain. Inequality in sales revenues, switches in trader types between seasons, quality and weights standardization, and the behavior of traders were used to examine market conduct. Performance was assessed by examining traders' costs and margins, and the spatial and temporal integration of maize markets.

We find that Malawi's maize market is pyramidal in structure and highly competitive at lower tiers of trade but 'oligopolistic' at higher tiers. The market channels vary across seasons with switches between trader types and instances of rural-urban trade reversals. There is considerable inequality of sales revenues among traders of similar capacities, and a widespread lack of structured trading despite existing institutions. A high ratio of marketing costs to revenue suggests marketing inefficiencies. Malawi maize prices were highly seasonal and more volatile than neighboring countries. In contrast to previous studies, our findings show weak spatial integration of markets and slow price adjustments to long-run equilibrium values even among short-distance market pairs.

The study highlights five pathways to improving Malawi's maize marketing system: (1) increased policy predictability to promote private-sector investment; (2) institutionalization of quality grades and standardization of weights and measures; (3) increased commercialization of smallholder maize production; (4) investment in enabling infrastructure; and (5) the promotion of structured trading.

Key words: Structure-Conduct-Performance, maize market, small traders and farmers, Malawi 


\section{INTRODUCTION}

Many studies have analyzed commodity value chains in developing countries, but only a few have focused on the inter-seasonal analysis of the structure, conduct, and performance (SCP) of specific staple food crops. The SCP of food markets influences the food distribution system from production to consumption. This significantly impacts food availability and prices, with far reaching implications on food and nutrition security. In Africa south of the Sahara, one in every four people is undernourished (FAO, 2019). This region experiences significant food price and volume seasonality and price volatility, which negatively impact food and nutrition security (Minot, 2014; Gilbert et al., 2017).

One of the countries in Africa south of the Sahara with high staple food price volatility is Malawi (Gilbert et al., 2017). Maize is by far Malawi's most important staple crop and contributes about 66 percent of calories to typical household diets (World Bank, 2017). The crop, which contributes 45.2 percent to the Consumer Price Index, is both a food crop and a raw material for agro-industries and generates employment for millions. Indeed, Malawi's food security is often defined in terms of availability of and access to maize (Derlagen, 2012). Hence, effective and efficient maize marketing contributes significantly to food and nutrition security, poverty reduction, and rural development.

Like many eastern and southern African countries, Malawi's maize market has been characterized by cyclical price volatility and volume seasonality (Jayne et al., 2010; Gilbert et al., 2017). In this study, we investigate the SCP of Malawi's maize market more broadly using panel data collected from 418 small traders and 480 small farmers during the main harvest and lean seasons of $2018 / 2019$, as well as weekly and daily maize retail price data from 13 regional markets.

Existing studies on maize price volatility and seasonality in Malawi have yielded mixed conclusions especially about spatial and price efficiency in the maize market. However, there is little knowledge of the variations in structure of maize marketing across seasons that might influence conduct and performance of the maize market, and challenges in maize marketing in this context. Except for a study by Jayne et al. (2010), this is the only other study that has examined the structure, conduct and performance of maize market across agricultural seasons. We extend and update Jayne et al's work by examining inequality in sales revenues, switches in trader types between seasons, quality and weights standardization, the risk attitudes of traders and their influence on maize trade as indicators of market conduct. We also assess spatial and temporal performance of maize markets and cover more districts and markets than Jayne et al. (2010).

This study is important for three reasons. First, examining market structure explains the constellation of marketing channels and actors, as well as the strengths and weaknesses of the maize marketing system. Second, analyzing the conduct (and perceptions) of maize farmers and traders provides insights into the dynamics of their participation in the maize market. This can facilitate the development of structured markets and viable market innovations such as contract farming. Lastly, analyzing the performance of markets sheds light on potential areas for improvement in the marketing of Malawi's main staple food.

The analysis of market performance developed in this study can support price stabilization efforts (i.e. spatial market integration, price volatility and seasonality), maize volume stabilization (i.e., warehousing, trader capacities, post-harvest management), and restructuring of the marketing channels to ensure equity in the distributional gains from maize marketing (inequality measures). The analysis can also help shed light on improvements in the enabling environment (i.e., financing, road and telecommunications infrastructure) to facilitate more efficient food marketing.

The rest of the paper is organized as follows: Section 2 provides the study context, Section 3 outlines the materials and methods used in analyzing SCP of the maize market, and Section 4 discusses the study's findings by first providing a profile of maize farmers and traders and then discussing the structure, conduct and performance of the maize market as a whole. Section 5 concludes with some key policy implications. 


\section{STUDY CONTEXT}

Malawi's population is 17.6 million people according to the September 2018 Census. With an annual growth rate of 2.9 percent (NSO 2018) the population is projected to reach 43.2 million by 2050. Agricultural production particularly of maize needs to increase to meet the demands of the growing population. Non-seed maize is largely produced by smallholder farmers (SHFs) - about 75 percent of smallholder farm plots (0.6 hectares on average) are under maize (World Bank, 2017). However, this is subsistence-oriented production with limited surpluses marketed. Large-scale farmers who could produce enough maize to ensure maize sufficiency shy away from non-seed maize production. A study by Edelman et al. (2016) revealed that large-scale farmers with at least 300 hectares (ha) only allocated 6 percent of their land to non-seed maize production due to an unpredictable maize marketing environment (in terms of price volatility, demand uncertainty, and intransparent policy interventions that restrict maize trade, mainly the export of surpluses). Largescale non-seed maize production was solely under contractual arrangements.

Maize production has significantly increased over the years due to increased demand and intensified use of improved technologies such as new varieties, inorganic fertilizers, and crop chemicals (Lunduka et al., 2012). The national Agricultural Production Estimates (APES) show that maize production increased by 31 percent between 2008 and 2017, but yields fell from $1,649.8 \mathrm{~kg}$ per hectare in 2008 to 1,467.5kg per hectare by 2018 (MoAIWD, 2019). Statistics show that the per capita consumption of maize grew from 129kg/year in 1998-2008 to $146 \mathrm{~kg} / \mathrm{year}$ by 2017 (FAOSTAT). Figure 1 shows the position of farm households in maize marketing during the 2015/16 season. About 72 percent of farm households bought maize but did not sell any of their harvested stocks. This represents a 17 percent increase from the 2008/09 estimate by Jayne et. al (2010). Another 12 percent of farm households neither sold nor bought maize during the same period.

Figure 1: Types of maize farmers in Malawi

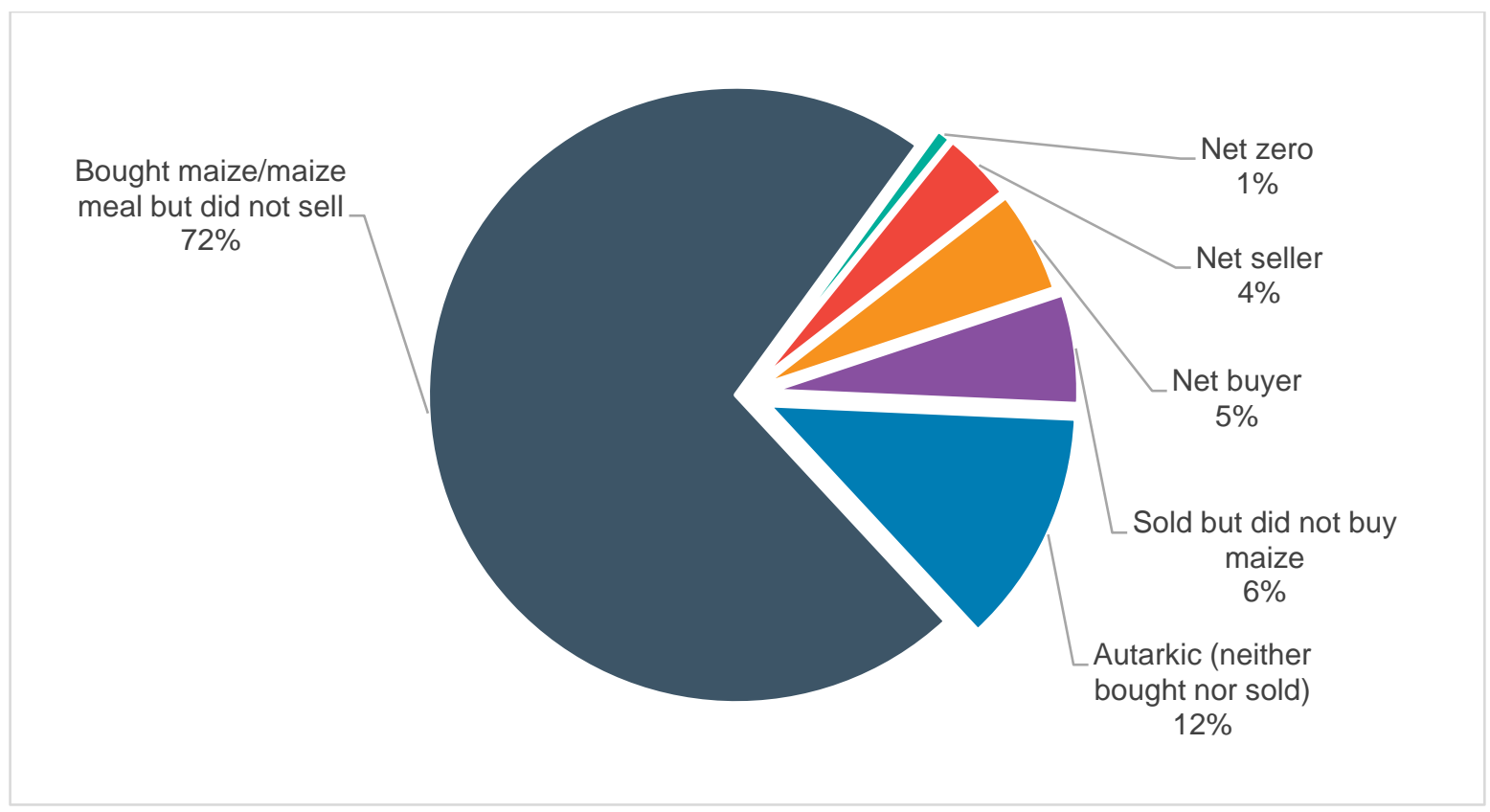

Source: Authors' construction from Agricultural Input Subsidy Survey data 2015/16.

Malawi experiences seasonal fluctuations in maize prices and volumes due to a combination of various factors including: (1) variations in timing of the main harvests across the southern, central, and northern regions of Malawi; (2) unexpected disasters such as floods and pest infestations; (3) production fluctuations; (4) global price fluctuations, and (5) policy interventions (FEWS NET, 2018). 
Maize harvesting begins in the South and progresses to the Center and finally to the North. This significantly influences the flow of maize across regions. Maize prices are usually high at the peak of the lean season but gradually decline towards the onset of the main marketing season.

Malawi's maize price volatility and seasonality are among the highest in the southern Africa region (Gilbert et al., 2017). Given the economic, food security and nutrition importance of maize, the Government of Malawi (GoM) is faced with the usual food price dilemma to keep the producer prices high enough to incentivize greater production and consumer prices low enough to stimulate consumption (Timmer et al., 1983). The Government of Malawi therefore controls maize marketing through several policy measures, such as export bans, domestic trade restrictions, and minimum farm gate pricing (Edelman and Baulch., 2016). Stock levels are controlled through the National Food Reserve Agency (NFRA) and the Agricultural Development and Marketing Corporation (ADMARC) in a bid to stabilize prices and volumes traded. The NFRA is responsible for holding physical grain stocks and funds necessary for use if the private sector fails to satisfy the national grain requirements. ADMARC is mandated to provide readily available markets for farmers for all agricultural commodities and inputs. The parastatal implements government agricultural policies such as food security and price stabilization and contributes to macroeconomic development through marketing of agricultural commodities to both local and export markets. However, ADMARC's buying and selling operations are limited to 5 to 10 percent of the marketed volume of maize (Jayne et al., 2010). Some studies argue that ADMARC interventions add some uncertainty into maize markets, reduce private sector participation, and can contribute to maize price volatility (Jayne et al., 2010; Edelman et al., 2016; Porteous, 2017).

\section{MATERIALS AND METHODS}

This section provides an overview of the sampling procedures and sources of data used for this study. It also discusses the analytical techniques that yielded our findings.

\subsection{The sample}

A multistage sampling procedure was used to sample small maize traders (with annual turnover of not more than 20 tons) and farmers from eight districts in Malawi: Blantyre and Mulanje in the South; Lilongwe, Mchinji, Ntchisi in the Center; and Mzimba, Chitipa and Karonga in the North. A total of 74 markets were sampled and balanced in terms of covering rural and urban markets, border and interior markets, and structural maize deficit and surplus area markets. Therefore, this selection can be considered as broadly representative of markets in Malawi to analyze price volatility and spatial market integration. The choice of market pairs in the integration analysis was based on the interview with traders on source markets for maize. Figure 2 shows a few of the key markets sampled. A full list of the markets can be found in Table A.1 in the Appendix. 


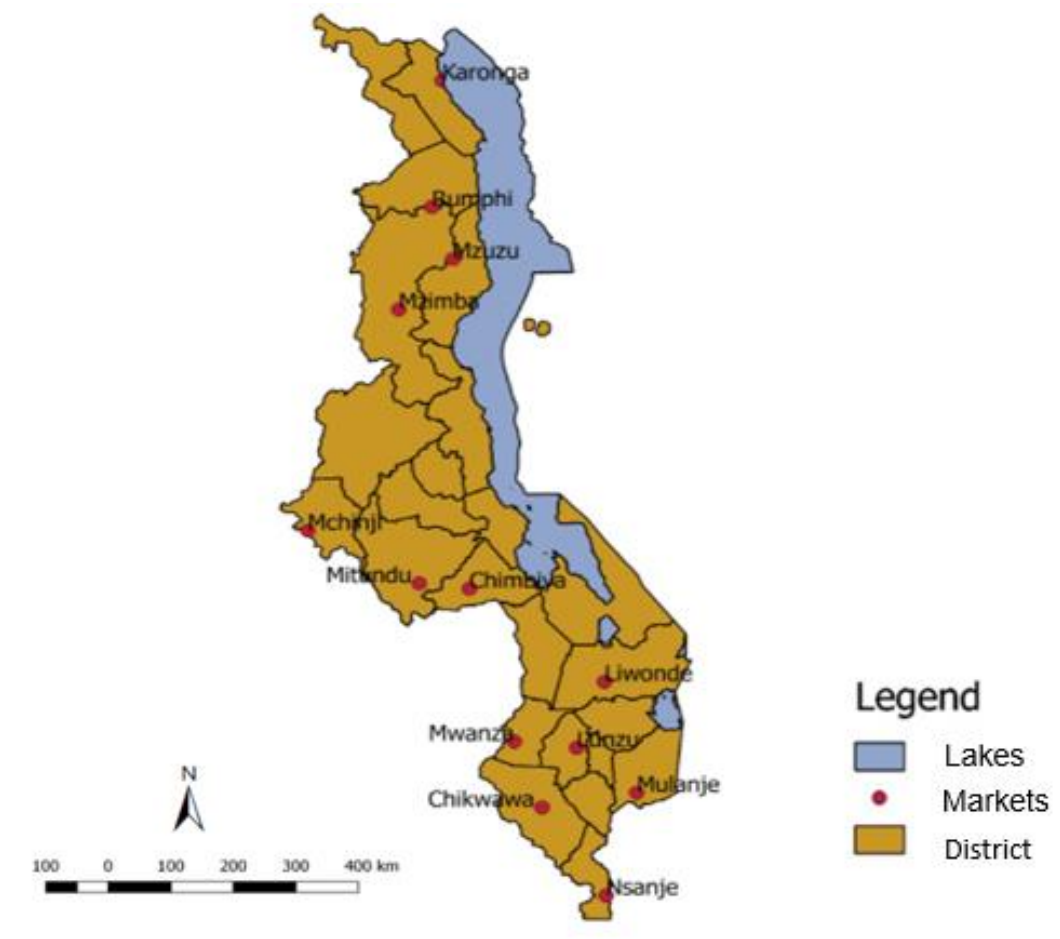

Source: Author's construction.

Note: The boundaries and designations used on maps do not imply official endorsement or acceptance by IFPRI.

A list of traders was obtained from the Cereal Traders Association of Malawi and systematic random sampling procedure used to sample traders from each market. A total of 555 traders were sampled in the main harvest season (June/July 2018) and 605 traders during a follow up survey in the lean season (January/February 2019), from which a panel of 408 traders was obtained. ${ }^{1}$ The large private traders with higher annual turnover and significant warehousing capacities were excluded from the sample as we focused on four types of traders: assemblers, agents, retailers, and wholesalers.

To sample farmers for FGDs, two Extension Planning Areas (EPA) were purposefully selected in each district where traders were sampled. At least two farmers associations were sampled from each EPA. Systematic random sampling procedure was then employed to sample 15 farmers from each farmers association for the FGDs. A total of 28 FGDs were held with a total of 480 farmers. This was to corroborate the findings from the trader surveys and provide a holistic view of the maize market from both supply (farmers) and demand side (traders) perspectives.

\subsection{Data and sources}

\subsubsection{Maize retail price data}

The study used daily and weekly retail maize price data from IFPRI, Mobile Vulnerability Analysis and Mapping (mVAM), WFP, and the Food and Agriculture Organization of the United Nations (FAO). The retail price data used to analyze spatial market integration ranged from December 2016 to July 2018 while prices used to analyze price seasonality ranged from 1989 to 2018. Consumer

\footnotetext{
${ }^{1}$ The study classified market actors based on volume traded, legal status, and self-reported information. Following advice obtained from local agricultural extension offices, wholesalers were classified as those that traded volumes of not less than 10MT during the season while retailers sold volumes of less than $10 \mathrm{MT}$. Assemblers and brokers were classified by the legal status of their trading business and/or the self-reported information.
} 
price indices data sourced from the Reserve Bank of Malawi and the International Monetary Fund were used to deflate prices to the levels of January 2010.

Since November 2016, IFPRI has collected daily retail maize prices from 16 major markets distributed across the three regions of Malawi while WFP collects weekly price data from 74 markets. The daily and weekly price data aided in analysis of spatial market integration across major markets while WFP and FAO (FAOGIEWs) data facilitated analysis of maize price volatility in Malawi and other countries.

\subsubsection{Maize transfer cost data}

This study also gathered data on transfer costs. These refer to the total costs of moving maize from one market to another (Baulch et al., 2008). In theory, transfer costs should also include rent, utilities, labor, and the returns to the trader (returns to labor and capital and risk premium), though these are likely to be a small part of the total. This implies that trade may not be profitable until the price differences are somewhat higher than the (estimated) transfer costs.

Transfer costs are important in modelling spatial market integration as they represent a wedge between prices in separate markets of the same product. This results in a non-linear relationship between prices in separate markets, contrary to the assumption made in most market integration studies.

Interviews with maize traders and transporters during the study period showed that the average cost of transporting maize was around MWK65/ton/km, while loading and off-loading costs MWK50 and MWK30 per $50 \mathrm{~kg}$ bag, respectively. The transportation costs included unofficial fees at roadblocks. The costs were elicited for the key maize transportation corridors. The study assumed symmetric transfer cost between market pairs.

\subsubsection{Other data}

We also used data on maize marketing environment from trader survey data during the main harvest and lean seasons of 2018/19 and FGDs data from farmers during the main harvest season. The respondents were asked about the market structure, perceptions and conduct of chain actor and performance of the market. The data aided in the analysis of the maize marketing channels across seasons, conduct of traders in response to the dynamic marketing environment and market performance.

\subsection{Analytical methods}

\subsubsection{Qualitative analysis}

Qualitative data from FGDs with farmers were collected using digital recorders. The recordings were translated, transcribed, and thematically coded using NVivo 12 plus. In addition, summaries of the themes were made from cross-case analysis. Similarly, open-ended responses from the semistructured interviews with traders during the main harvest and lean seasons of 2018/19 were also coded and summarized from cross case analysis. Data from KIls with market leaders (usually an influential trader in the market) on the maize market were also coded and analyzed.

\section{Structure of the maize market}

Traders and farmers were asked about their sales and purchases activities, the level of competition in the market, and the evolution of the marketing channel. KIls with market leaders aided in understanding the structure of the market, augmented by the descriptive statistics from trader survey data in the main market and lean seasons. The summaries from the FGDs transcriptions also aided in analyzing farmer responses on the structure of the maize market. Perceptions of traders and farmers of the maize market were also elicited. 


\section{- Analyzing conduct of actors in the maize market}

To analyze conduct of chain actors, the study used a combination of descriptive statistics from trader survey data, summaries from FGD transcriptions, and KIls with market leaders. Conduct was analyzed in terms of maize purchases and sales patterns and modalities across seasons, price setting mechanisms, nature of competition, market innovations (i.e. contracts), marketing strategies, risk management practices of traders and farmers, and the enabling environment (i.e. financing, market information). We plotted Lorenz curves for revenues to show inequality in revenue distribution by trader types. Theil's index was also decomposed to analyze inequality of gross revenues within and between trader types.

\section{- Analyzing performance of the maize market}

To investigate performance of the maize market, trader survey data was analyzed using both descriptive and quantitative approaches described below. Descriptive statistics were used in seasonal comparisons of maize volumes and price dynamics, gross margins, marketing costs, warehousing capacities, and contractual arrangements. Theoretically, traders are expected to maximize utility by minimizing market efficiency ratios (reducing expenses and increasing earnings). Marketing efficiency was analyzed using the efficiency ratios, which refers to how much a trader spends to make one Malawi Kwacha (MWK) in the maize business. High ratios indicated reduced marketing efficiency of traders since more costs were incurred for every additional MWK earned and vice versa.

\subsubsection{Quantitative analysis}

In terms of quantitative analysis, various quantitative approaches were employed to analyze market performance:

i) A Grand Seasonal Index (GSI) to analyze maize price seasonality.

ii) A threshold error correction model to analyze spatial market integration and price adjustments between markets.

iii) Standard deviation of price returns to analyze maize retail price volatility.

\section{Analyzing price seasonality}

Measuring the extent of price seasonality involved three steps. First, we determined the moving seasonal averages, then constructed seasonal price indices, and finally constructed the grand seasonal indices. The GSI measures how prices in a month of a full production cycle compare with the average price of that production cycle. The GSI describes the extent of seasonal price swings in various markets used in the study. The number of percentage points a grand seasonal index deviates from the value 100 shows the extent of seasonality.

A price series can be represented by four components: (1) the trend component, (2) the cyclical component, (3) the seasonal component, and (4) the error component.

$$
p_{y t}=\tau_{y t} \times c_{y t} \times s_{y t} \times \varepsilon_{y t}
$$

where $p_{y t}$ represents the price in month $t$ and year $y . \tau_{y t}$ represents the trend term; $c_{y t}$ is the cyclical component; $s_{y t}$ is the seasonal component and $\varepsilon_{y t}$ represents the error term. The trend component represents general economic factors such as rising demand due to population increase or inflation. The cyclical component represents unforeseen production fluctuations associated with erratic weather patterns that may increase or reduce production. The seasonal component results from the relatively costly storage to bridge a discontinuous flow of supply with a continuous demand of a product over an annual cycle. The error component comprises of all events that may not have been captured in the three components discussed earlier (such as changes in government policy). 
Since our interest lies in the seasonality, the trend and cyclical components have to be removed. Equation 1 therefore becomes:

$$
s_{y t} \times \varepsilon_{y t}=\frac{p_{y t} s_{y t} \times \varepsilon_{y t} \times \tau_{y t} \times c_{y t}}{\tau_{y t} \times c_{y t}}
$$

The first step is to create a Moving Seasonal Average (MSA) of the $p_{y t}$ values, which involves estimating $\tau_{y t}$ and $c_{y t}$ jointly as $\tau_{y t} \times c_{y t}$. If the random component is truly random, a moving average removes the random component because the average of all random components for all the observations would be zero. The moving average also removes the seasonal component if the moving average is for one season in length.

With a 'moving' average, the seasonal average changes with each observation. The advantage of the MSA is its ability to remove shorter-term fluctuations in the series caused by the random and price seasonality factors, which then allows one to concentrate on cycles $\left(\tau_{y t}\right)$ and trends $\left(c_{y t}\right)$ (Goetz and Weber, 1986). The seasonal average of each observation includes a half-season behind and a half-season ahead. The seasonal average is therefore centered on each observation. Since maize is an annual commodity with a single rainy season, the season is defined as 12-months. The equation for calculating $\tau_{y t}$ and $c_{y t}$ is therefore based on monthly average price data with a season length of 12-months. However, since 12 is an even number, this method will have to be adjusted to allow for a centered moving average. The moving seasonal average is therefore calculated as:

$$
\begin{aligned}
& M S A_{t} \\
& =\frac{P_{t-6}+2\left(P_{t-5}\right)+2\left(P_{t-4}\right)+2\left(P_{t-3}\right)+2\left(P_{t-2}\right)+2\left(P_{t-1}\right)+2\left(P_{t}\right)+2\left(P_{t+1}\right)+2\left(P_{t+2}\right)+2\left(P_{t+3}\right)+2\left(P_{t+4}\right)+2\left(P_{t+5}\right)+P_{t+6}}{24}
\end{aligned}
$$

The values of $P_{t-6}$ and $P_{t+6}$ are the only values not multiplied by two because each of these months loses one-half to make sure that the calculated seasonal average is centered. Hence, data points at the beginning and end of the price series are lost, implying that the first and last six observations in the price series do not have moving averages. From 12 data points for each month during the 30 years, we obtained a total of 360 data points. Six data points were lost at the beginning of the price series for the moving average to be centered. This explains the 354 (360-6) seasonal indices for later computations in equation 5.

The Seasonal Index (SI) is then calculated as follows:

$$
\begin{gathered}
s_{y t} \times \varepsilon_{y t}=\frac{p_{y t}}{\tau_{y t} \times c_{y t}} \\
=\frac{p_{y t}}{M S A_{y t}} \\
\text { Seasonal Index }=S I_{t}=\left(S_{y t} \times \tau_{y t}\right) \times 100
\end{gathered}
$$

If $p_{y t}$ equals its own MSA, then the seasonal index would be 100. A seasonal index is therefore calculated for each $p_{y t}$. For example, if the SI for month $\mathrm{m}$ and year $\mathrm{y}$ is 120 , it implies that the price in that month is 20 percent higher than the 12-month moving average. If the same seasonal index of 120 is obtained for month m of all years under study, we can then conclude that prices in month $\mathrm{m}$ are typically 20 percent above the annual average. If no price seasonality exists, the seasonal indices from January to December will not be significantly different from 100 . Since the seasonal index is calculated as a ratio of moving seasonal averages, there is no need for the price series to be deflated (Goetz and Weber, 1986). 
The final step is to calculate the GSI for month $m$, which is the mean of all seasonal indices for the month $m$ over all the years of the price series as shown in equation 5 . The error component is therefore removed from the price series and each calendar month has one GSI.

Since our study covered a period of 30 years (1989-2018), the GSI was calculated as follows:

$$
G S I_{m}=\frac{I_{t}+S I_{t+12}+S I_{t+24}+S I_{t+36}+S I_{t+48}+\ldots S I_{t+354}}{30}
$$

The calculated GSI rarely equals to 100 due to rounding-off errors. Given the procedure outlined, the expected value of GSI for all 12 months of the year is expected to be 1200 (12 months $\times 100$ ). But in most cases, the value obtained slightly deviates from 1200. To correct this, an adjustment factor is often used on the GSIs to make sure that the total sums up to 1200 . For example, if the total of all GSIs is 1193, then the adjustment factor becomes $1200 / 1193$ and is multiplied to all monthly GSIs. This adjustment does not change the relative seasonality positioning of each month against other months. It also does not change the percentage degree of seasonality represented by the index.

\section{- Analyzing spatial market integration}

In testing for market integration, we employ a threshold error correction model as applied by Baulch et al. (2008). This approach uses empirical estimates of transfer costs in the model to define regimes under which spatial arbitrage is likely to take place. We assume that the transfer cost between a market pair is the same regardless of the direction of spatial arbitrage. This implies that there are three scenarios in which prices may respond due to a change in price in another market.

The scenarios are described as regimes: upper, lower and no trade. The 'upper' regime is when the price in market $a$ is greater than the price in market $b$ plus the transfer cost, thus $\left(p_{a} \geq p_{b}+t c\right)$.

Traders will therefore move the commodity from market $b$ to $a$, as it will be profitable for them to do so. In the process, prices will move toward each other as the volumes adjust in the two markets. The 'lower' regime refers to when the price difference between market $b$ is greater than the price in market a plus transfer cost $\left(p_{b} \geq p_{a}+t c\right)$. Finally, the 'no-trade' regime is when the price difference in the two markets is less than the transfer cost such that spatial arbitrage is unprofitable. i.e. $p_{a}-$ $t c<p_{b}<p_{a}+t c$. An error correction model is thus formulated, allowing for lagged price variables and autoregressive parameters as follows:

$$
\Delta p_{a t}=\varphi^{s} \Delta p_{b t}+\delta_{1}^{s} \Delta p_{a t-1}+\delta_{2}^{s} \Delta p_{b t-1}+\alpha^{s}\left(p_{a t-1}-\beta^{s} p_{b t-1}-\mu^{s}\right)+\emptyset^{\prime} S_{t}+\varepsilon_{t}
$$

Where, $\Delta$ is the difference operator, $p_{a t}$ is the price of maize in market a at time t, $p_{b t}$ is the price maize in market b at time $\mathrm{t}, \delta_{1}^{S}$ and $\delta_{2}^{S}$ are regime specific parameter estimates of maize prices in market $\mathrm{a}$ and $\mathrm{b}$ respectively after first differences, $\varphi^{s}$ represents the regime specific parameter estimate on the differenced price in market $\mathrm{b}, \alpha^{s}$ is the regime specific speed of adjustment parameter, $\emptyset$ represents the parameter estimates on seasonal dummies and $\varepsilon_{t}$ is the error term. $A$ test for the optimal lag order using the Akaike Information Criteria (AIC) chose two lags. We therefore use the same in describing the distributed lag model.

A series of market integration tests are conducted based on the model in equation (6) including tests for long run integration, common dynamics in prices and Law of one Price. A detailed description of how these hypotheses are tested can be found in Ochieng et. al. 2018.

\section{- Model robustness}

Preliminary estimation of the threshold error correction model using Ordinary Least Squares (OLS) showed that the model suffered from heteroskedasticity and autocorrelation. This implies that the OLS estimator was not the best linear unbiased estimator. The threshold error correction model was 
therefore estimated using Newey-West standard errors, which assume heteroskedasticity and autocorrelation of some same order. ${ }^{2}$

\section{Analyzing price volatility}

Food price volatility has mostly been assessed using the coefficient of variation defined by $\mathrm{CV}=\sigma / \mu$ where $\sigma$ is the standard deviation and $\mu$ is the mean of the price over a given period. However, this measure may be misleading when dealing with non-stationary time series, such as maize prices in Malawi, since variance and standard deviation of prices approach infinity as the time-period approaches infinity (Minot, 2014; Gilbert et al., 2017). In this paper, we therefore analyze maize retail (real) price volatility using the standard deviation of returns, which is the difference in the logarithm of prices from one time-period to another.

Volatility can therefore be measured as follows:

$$
\text { Volatility }=\operatorname{stdev}(r)=\left[\sum \frac{1}{N-1}\left(r_{t}-\bar{r}\right)^{2}\right]^{0.5}
$$

where

$$
\begin{gathered}
r_{t}=\ln \left(p_{t}\right)-\ln \left(p_{t-1}\right) \\
\bar{r}=\sum \frac{1}{N} r_{t}
\end{gathered}
$$

If prices follow a unit root process with a multiplicative disturbance term, $r_{t}$ will be stationary and its standard deviation will no longer tend to infinity as the sample size increases. Variance ratio tests were then used to assess whether there are significant differences between price volatility across markets.

\section{RESULTS AND DISCUSSION}

This section presents descriptive statistics of the sampled farmers and traders and discusses our qualitative and quantitative findings on structure, conduct and performance of Malawi's maize market over the 2018/19 main harvest and lean seasons. We first present a profile of the maize farmers and traders interviewed and follow this with a discussion of the structure of the maize market, which examines maize market channels, barriers to entry and the perceptions of farmers and traders about its competitiveness. Then, we describe the conduct of market actors by examining traders' marketing strategies, switches between trader types across seasons, and the seasonality of maize purchases and sales. This section also examines inequality in sales revenues between trader types, marketing information, price setting mechanisms, and trade financing. Finally, we examine the performance and efficiency of the maize market by analyzing traders' costs and margins, price seasonality and volatility, and the spatial and temporal integration of maize markets.

\subsection{Profile of maize farmers and traders}

This section provides an overview of the characteristics of farmers and traders interviewed during the two rounds of survey in the 2018/19 main harvest and lean seasons. Farmers were interviewed through FGDs while traders through face-to-face semi-structured interviews.

\footnotetext{
${ }^{2}$ Newey-West standard errors are calculated from a distributed lag of the OLS residuals, where the maximum lag at which the autocovariances are to be computed is specified. In a time-series context, they are robust to both arbitrary autocorrelation and heteroskedasticity. The rule of thumb in choosing the lag length of the order of autocorrelation is $0.75^{\star} T^{\wedge}(1 / 3)$, rounded to an integer, where $T$ is the number of observations used in the regression (Stock and Watson, 2011).
} 


\subsubsection{Profile of maize farmers}

Prior to FGDs, farmers were requested to register on a sheet of paper that had few questions on their demographic and agricultural production and marketing profiles during the main harvest season. Table 1 presents a summary of profile of farmers. Female farmers constituted 58 percent of the sample. The average farmer was about 39 years old with six years of schooling. Farmers planted about 1.3 acres of maize from which they harvested about ten $50 \mathrm{~kg}$ bags on average. For the 53 female and 47 male farmers that reported sales, about 17 percent of maize harvested was sold at an average price of MWK80 per $\mathrm{kg}$, which was nearly half the minimum farm gate price set by MoAIWD in mid-April 2018. About 49 percent of farmers owned mobile phones. Interestingly, there was a statistically significant difference in mobile phone ownership whereby more men (65 percent) than women (37 percent) owned phones.

\section{Table 1: Profile of maize farmers}

\begin{tabular}{|c|c|c|c|c|c|c|}
\hline \multirow[t]{2}{*}{ Variable } & \multicolumn{2}{|c|}{ All } & \multicolumn{2}{|c|}{ Women $(\mathrm{N}=\mathbf{2 8 0})$} & \multicolumn{2}{|c|}{ Men $(\mathrm{N}=200)$} \\
\hline & Mean & SD & Mean & SD & Mean & SD \\
\hline Age of farmer (years) & 38.9 & 13.6 & 39.0 & 13.2 & 38.8 & 14.1 \\
\hline Level of education (years) & 6.4 & 3.3 & 5.5 & 3.3 & 7.6 & 2.9 \\
\hline Area under maize (acres) & 1.3 & 0.9 & 1.2 & 0.9 & 1.3 & 0.9 \\
\hline Maize harvested ( $50 \mathrm{~kg}$ bags) & 10.0 & 10.1 & 7.9 & 7.5 & 12.9 & 12.3 \\
\hline Maize sales (\% of harvest) ${ }^{a}$ & 17.2 & 15.8 & 17.5 & 17.3 & 16.8 & 14.1 \\
\hline Price per kg sold ${ }^{a}$ & 76.7 & 35.6 & 80.1 & 46.6 & 72.8 & 15.7 \\
\hline Own a mobile phone (\% yes) & 48.5 & & 37.1 & & 64.5 & \\
\hline
\end{tabular}

Source: Authors' calculations based on registration data during FGDs.

Note: SD, standard deviation; a proportion of harvest sold and selling price is only reported for farmers who sold maize (53 women and 47 men); no statistically significant differences between women and men in all the profiles, except mobile phone ownership.

\subsubsection{Profile of maize traders}

Table 2 provides a profile of the sampled traders. There were four main types of traders in the maize market namely assemblers, brokers, retailers and wholesalers. About 78 percent of the traders interviewed by the study team were men, with the majority (51 percent) of traders between 36-50 years old. Youths (persons between 18 to 35 years) comprised a significant proportion of the traders at 42 percent. Many young traders were involved more in rural maize assembly while older ones were engaged in wholesaling. In terms of education the study found that traders had about nine years of schooling - at least some primary education and eight years of experience in maize trade. Overall, maize trade was the primary occupation for 77 percent of the traders.

In terms of legal status of the businesses, over 70 percent of the small maize traders operated without any form of registration. Moreover, a few traders were registered either at the local, district or national level. Notably, none of the assemblers and brokers were registered. The widespread informality of maize trade partly explains the limited market reach and the seasonal changes in scale of operation and trader types (later discussed under conduct of the maize market) because there are no legal implications of the changes.

The distances from traders' premises to the nearest alternative purchases and sales points were 25 and 11 kilometers $(\mathrm{km})$, respectively. This seems plausible, given the limited legal status of most 
traders that narrow their spatial scope of operation. Overall, maize was mainly traded within the village bases (62 percent). However, a significant proportion of traders operated outside their village bases and traded within the districts or towns based. Only eight percent of traders (mostly wholesalers) operated at national level. The reported exporters were basically operating at the border markets where trading was largely informal.

Maize supply imbalances between rural and urban markets lead to trade reversals across seasons whereby maize flows from rural to urban areas particularly during the main harvest season and vice versa during the lean season. Such reversals also influence the marketing channels and the aforementioned switched between trader types.

Table 2: Profile of maize traders

\begin{tabular}{|c|c|c|c|c|c|}
\hline Variable & $\begin{array}{c}\text { Assembler } \\
(n=45)\end{array}$ & $\begin{array}{l}\text { Broker } \\
(n=10)\end{array}$ & $\begin{array}{l}\text { Retailer } \\
(n=239)\end{array}$ & $\begin{array}{c}\text { Wholesaler } \\
(n=114)\end{array}$ & $\begin{array}{c}\text { All } \\
(n=408)\end{array}$ \\
\hline Gender (\% men) & 77.8 & 100 & 72.8 & 81.6 & 76.5 \\
\hline Age (average years) & 34.8 & 38.4 & 38.7 & 38.5 & 38.2 \\
\hline $18-35$ years $(\%)$ & 60.0 & 50.0 & 40.6 & 36.0 & 41.7 \\
\hline $36-50$ years $(\%)$ & 37.8 & 50.0 & 49.8 & 58.8 & 51.0 \\
\hline Above 50 years (\%) & 2.2 & 0 & 9.6 & 5.3 & 7.3 \\
\hline Years of schooling & 8.5 & 8.8 & 8.8 & 9.2 & 8.9 \\
\hline Experience in maize business (years) & 7.0 & 7.8 & 8.9 & 7.7 & 8.4 \\
\hline Trading as primary occupation (\% yes) & 84.4 & 50.0 & 80.8 & 68.4 & 77.0 \\
\hline \multicolumn{6}{|l|}{ Legal status of business } \\
\hline Not registered (\%) & 71.1 & 70.0 & 84.5 & 62.3 & 76.5 \\
\hline Registered at local level (\%) & 6.7 & 10.0 & 2.1 & 2.6 & 2.9 \\
\hline Registered at district level (\%) & 22.2 & 10.0 & 2.1 & 13.2 & 7.6 \\
\hline Registered at national level (\%) & 0.0 & 10.0 & 11.3 & 21.9 & 13.0 \\
\hline Distance to alternative purchase point & 9.1 & 3.5 & 21.5 & 38.6 & 24.5 \\
\hline Distance to alternative sales point & 9.2 & 1.5 & 5.9 & 22.0 & 10.7 \\
\hline \multicolumn{6}{|l|}{ Market reach } \\
\hline Within village based & 82.2 & 60.0 & 63.2 & 50.9 & 61.8 \\
\hline Within town but outside village based & 68.9 & 50.0 & 40.6 & 43.9 & 44.9 \\
\hline Within district but outside town based & 42.2 & 30.0 & 36.4 & 46.5 & 39.7 \\
\hline Within region but outside district based & 4.4 & 10.0 & 22.2 & 30.7 & 22.3 \\
\hline Within Malawi but outside region based & 0.0 & 10.0 & 5.9 & 14.9 & 7.8 \\
\hline Outside Malawi & 6.7 & 0.0 & 5.9 & 5.3 & 5.6 \\
\hline
\end{tabular}

Source: Author's calculations from SCP survey data (Jun/Jul 2018 and Jan/Feb 2019).

Table 3 presents a summary of percentage of maize traders' access to productive assets and human capital vital to maize trade. In terms of storage facilities, about half of the sampled traders owned warehouses and another 40 percent rented warehouses for maize storage. The average capacity of the owned warehouses was about 37 metric tons (MT). Apart from wholesalers, a few traders owned buildings (excluding storage facilities). 
Most traders did not own quality management equipment including cleaning, drying or bagging equipment, and moisture meters. Traders attributed this to lack of price premium and demand for quality maize beyond what was already supplied. Interestingly, moisture meters were the least owned equipment yet one of the most critical to monitor the moisture content and prevent aflatoxin contamination. Also, purchases of maize with high moisture content lead to weight losses and thus less profit. Most of the traders owned weighing scales (70 percent), which were used more during maize purchases than during sales, particularly in the North where pails were preferred to weighing scales. The traders employed about eight workers on average, half of whom were paid workers while the rest were family members.

Table 3: Facilities and assets of maize traders

\begin{tabular}{|c|c|c|c|c|c|}
\hline Variable & $\begin{array}{l}\text { Assembler } \\
(\mathrm{n}=45)\end{array}$ & $\begin{array}{l}\text { Broker } \\
(n=10)\end{array}$ & $\begin{array}{l}\text { Retailer } \\
(\mathrm{n}=239)\end{array}$ & $\begin{array}{l}\text { Wholesaler } \\
(n=114)\end{array}$ & $\begin{array}{l}\text { All } \\
(n=408)\end{array}$ \\
\hline Access to long term storage facility ( $\%$ yes) & 71.1 & 40.0 & 63.6 & 70.2 & 65.7 \\
\hline Own warehouse (\% yes) & 37.5 & 50.0 & 34.2 & 50.0 & 39.6 \\
\hline Own warehouse capacity (in MT) & 33.4 & 100.0 & 12.8 & 65.1 & 36.5 \\
\hline Rented warehouse (\% yes) & 49.9 & 25.0 & 52.6 & 43.8 & 48.9 \\
\hline Owned buildings (excluding storage) (\% yes) & 23.3 & 20.0 & 30.1 & 52.6 & 36.5 \\
\hline Owned weighing scales (\%) & 66.7 & 90.0 & 64.9 & 79.8 & 70.0 \\
\hline Owned cleaning/drying equipment (\%) & 13.3 & 10.0 & 13.4 & 13.2 & 14.0 \\
\hline Owned bagging equipment (\%) & 8.9 & 0.0 & 14.2 & 13.2 & 13.0 \\
\hline Owned vehicles (\%) & 4.4 & 0.0 & 5.0 & 24.6 & 10.3 \\
\hline Owned oxcarts (\%) & 4.4 & 10.0 & 5.4 & 7.0 & 5.9 \\
\hline Owned maize mills (\%) & 4.4 & 0.0 & 1.3 & 5.3 & 2.7 \\
\hline Owned moisture meters (\%) & 2.2 & 0.0 & 0.8 & 2.6 & 1.5 \\
\hline Number of workers & 8.0 & 8.0 & 8.0 & 8.0 & 8.0 \\
\hline Number of paid workers & 4.0 & 4.0 & 4.0 & 4.0 & 4.0 \\
\hline
\end{tabular}

Source: Author's calculations from SCP survey data (Jun/Jul 2018 and Jan/Feb 2019).

Note: * differences in capacities are significant at the $1 \%$ level across trader types.

\subsection{Structure of Malawi's maize market}

This section discusses the structure of Malawi's maize market. We begin by describing the marketing channels through which maize flows from farm gate to consumers across seasons then narrow down to farmers' and traders' perception of the market, enabling environment, and other chain actors including ADMARC. Maize marketing channels usually involve several intermediaries with occasional value addition along the marketing processes.

\subsubsection{Maize marketing channels}

Figure 3 shows a flow diagram of maize marketing channels from farmers through various market actors to consumers and other end users during the 2018 main marketing season. The diagram shows the main channels but does not represent all possible channels. Nonetheless, it reveals an intricate web of intermediaries in the maize market. The survey respondents (traders and farmers) mentioned that maize marketing channels changed across seasons and depended on the nature of harvest, prevailing maize trade policies (export bans and trade restrictions) and declarations of natural disasters/emergencies that affected availability of maize in the markets. This was also observed by Jayne et al (2010). 
Farmers interviewed in the FGDs sold their surplus maize mainly to assemblers and retailers directly and indirectly through agents to large private traders and processors. None of the SHFs interviewed sold maize under contracts during the two seasons. While not shown in the flow diagram, a few pockets of farmers sold maize to Agricultural Commodity Exchange for Africa (ACE) through farmers' associations certified by ACE. There was hardly any farmers marketing maize through cooperatives, and this eroded their bargaining power in pricing, owing to the small volume and uncoordinated manner of sales.

\section{Figure 3: Maize marketing channels}

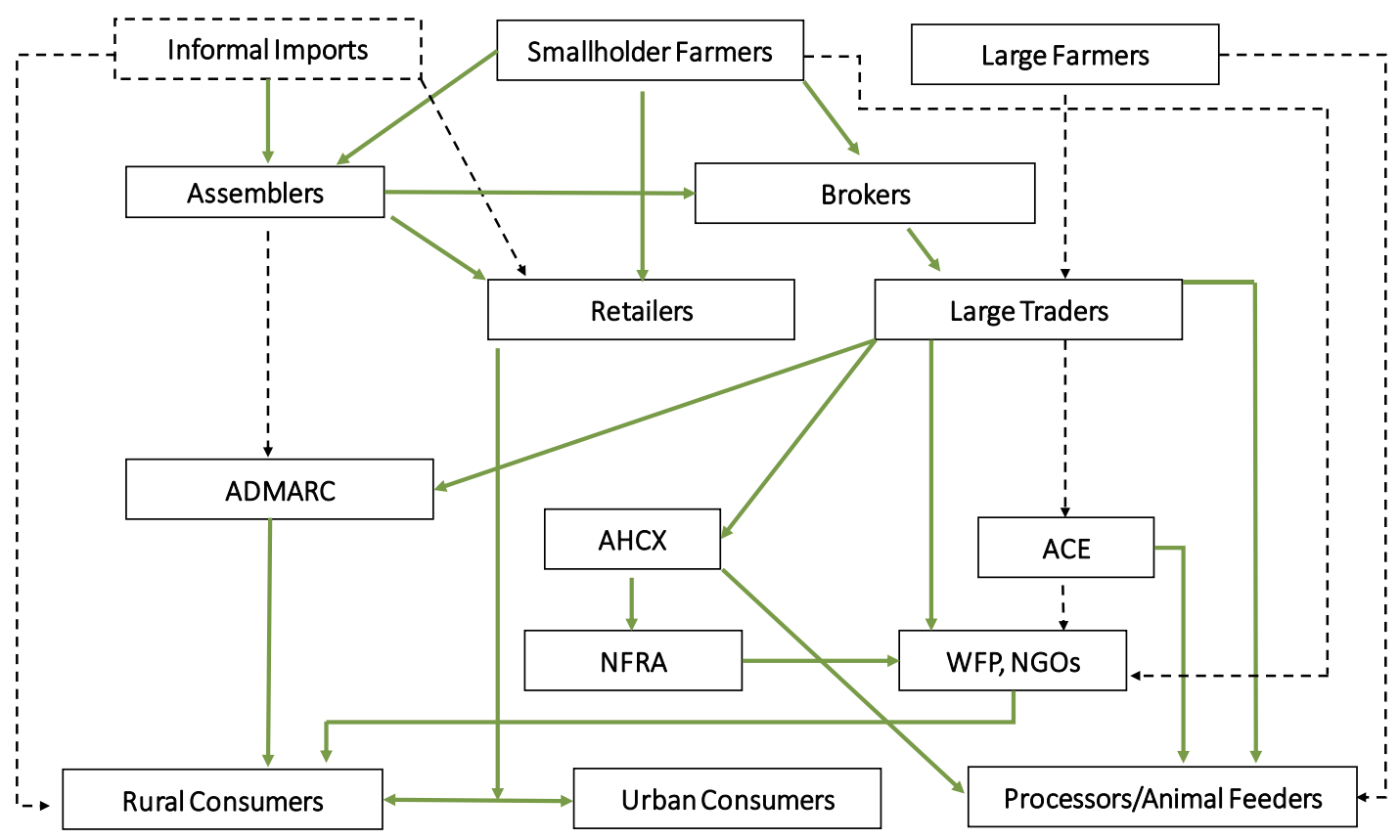

Source: Authors' construction from IFPRI Survey Data.

Note: Solid green lines represent major flows, dashed black lines represent minor flows.

Maize assemblers were at the fulcrum of maize distribution beyond the farm. Two distinct types of assemblers were interviewed during the surveys. One type, a lower tier of assemblers, operated mainly at the village level, assembling maize from farms/neighboring countries' borders and at designated points with weighing scales mounted on makeshift tripod stands along rural roads. These assemblers mainly transported maize by bicycle, oxcart, or on foot on their heads. A second type, a higher tier of assemblers, assembled maize from village assemblers, retailers, or large farmers and then sold to large traders, processors/animal feed processors, and ADMARC. This type of assembler spontaneously moved around villages or rural markets with lorries to purchase maize. A few of them had repeated transactions with suppliers, but most confined themselves to nonbinding agreements through occasional phone calls to aggregate specific quantities of maize prior to their purchasing visits.

Both urban and rural maize retailers mainly purchased the crop from farmers and assemblers and then sold largely to urban consumers or to ADMARC. During the first survey round in the main marketing season there were export bans imposed in Malawi, Mozambique, and Zambia. However, for a country like Malawi with long porous borders, informal imports and exports are inevitable. Domestic retailers in border locations often purchased maize from across borders, while foreign assemblers sold to Malawi retailers (either directly or through their agents). Many such cases were reported in Mchinji and Nthalire, which border with Zambia, Limbuli on the border with Mozambique, and Chitipa on the border with Tanzania. Maize was purchased and stored by traders for limited time periods in anticipation of higher prices and then sold at the peak of the lean season or just as 
the main harvest period began, before the cheap 'new' maize entered the market. New maize refers to the just harvested maize during the main harvest marketing season.

Large maize traders aggregated maize from farmers and higher tiers of assemblers and sold to ADMARC, processors/animal feeders, WFP, and non-governmental organizations involved in relief food distribution particularly during floods and prolonged dry spell. Large maize traders also used the two commodity exchanges, Agricultural Commodity Exchange for Africa (ACE) and Auction Holdings Commodity Exchange (AHCX). Compared to other trader types, large traders have the financial capacity and access to bank credit to aggregate large volumes of maize, which enables them to store in warehouses for longer time periods. Therefore, large traders had a competitive edge over small farmers and traders in selling to ADMARC, which typically only begins purchasing late in the main marketing season after the national budget is approved in late June or early July/August.

At the time of both surveys, clear figures on the detailed stocks held by large traders could not be obtained, but it appeared that they held large stocks in their warehouses. This information gap indicates lack of coordination between the GoM and other maize value chain actors to organize or forecast maize production and marketing that would incentivize private sector investment in maize marketing. Because of mistrust and possibly 'tax avoidance', different market players do not freely share information on stocks held, leading to erratic variations of maize availability and requirements in any given year. The lack of information on available maize stocks held by traders complicates computation of reliable estimates in the food balance sheets for Malawi. This hinders price stabilization efforts, which can be facilitated through planning around production and marketing, anticipating shortfalls and mitigating future high price volatility.

At the time of the main harvest season survey, the GoM contracted the NFRA to procure maize for the Strategic Grain Reserve (SGR), which commenced later in August 2018. NFRA in turn contracted AHCX to purchase 32,000MT of maize. About 172 traders supplied maize to AHCX at MWK150 per kg, the minimum farm gate price announced by the GoM at the onset of the maize marketing season.

ADMARC remains a key player in maize marketing in the country, especially in maize sufficiency and price stabilization efforts. The corporation aims to mop up excess maize from the market by purchasing at attractive prices after harvest to guarantee higher producer prices and then releases stocks at the peak of the lean season to lower consumer prices. Therefore, ADMARC normally tries to stimulate competition in the maize market. However, at the time of the main season survey, no ADMARC activities were reported in any of its depots visited by the survey team. As mentioned earlier, the corporation relies heavily on government financing, which delays until the tail-end of the main marketing season. Consequently, only a few SHFs sold to ADMARC, as most farmers' stocks were already sold to assemblers and traders.

Maize is also traded through the ACE and AHCX commodity exchanges. Both ACE and AHCX operate warehouse receipt systems (WRS) that allow depositors of grain to access credit with the deposits as collateral. The two exchanges, however, have operated at sub optimal levels, owing to low sales volumes and limited private traders' participation in the exchanges (Baulch et al., 2018a). In fact, even processors and animal feeders only turned to the exchanges in cases of procurement shortfalls. The GoM has traditionally given the two exchanges equal platform to thrive. Still, during the main marketing season, AHCX was contracted to purchase maize for SGR. Sales through commodity exchanges remained limited to a few traders. Many traders and farmers interviewed had negative perceptions of the exchanges. Farmers and traders believed that the fees charged absorbed all profits from WRS.

Malawi's maize market also has a small group of large traders that control markets in nearly all regions or within specific regions, especially in central and southern Malawi. This group of traders has connections from urban and peri-urban areas down to the villages. At the main urban centers, the traders assembled and stored maize in large private branded warehouses. These traders also 
rented houses at village level from where their employees purchased maize from farmers. The employees then moved from village to village purchasing stocks, which ultimately ended in warehouses at the urban centers. This market controlling group of traders could not be analyzed further as they declined our requests for interview.

\subsubsection{Barriers to entry into the maize market}

One of the ways to assess competitiveness of staple markets is to analyze the barriers to entry into the maize business, and threats to maize trade. The study elicited traders' perceptions of the maize market and the responses are shown in Table 4. On a scale of 1 to 4 (1=strongly agree, 4=strongly disagree), traders were asked about their views on the maize market as presented in the first two rows of Table 4. The 'yes' response is a summation of those who either agreed or strongly agreed with the statements. Most of the traders said that it was easy to start a maize business in Malawi (66 percent). About 60 percent agreed with the statement that quality standards were not a major barrier to entry. This is plausible, given that there were no set quality standards to be observed and quality depended on the buyer requirements. Quality was defined as the mere cosmetic appearance of the grain - size, color, cleanliness and texture - rather than the more rigorous requirements of moisture content and pest residue.

In terms of trade financing, many traders reported financial capital as a critical barrier to entry (85 percent) and a threat to maize business (47 percent). The unpredictable maize price was considered as the most cited threat to maize business. Malawi has one of the highest price volatility and seasonality records in East and southern Africa (Minot, 2014) and this could among other factors be a threat to spatial arbitrage and investment in maize storage for longer periods in anticipation of higher prices. Food distribution programs in Malawi were less perceived to negatively affect maize business by depressing prices due to increased supplies. A study by Baulch et al. (2018b) also did not find significant effects of maize distribution on maize prices under the Food Insecurity Response Program (FIRP).

Table 4: Perceptions of barriers to entry (\% yes)

\begin{tabular}{|c|c|c|c|c|c|}
\hline Variable & $\begin{array}{l}\text { Assembler } \\
(n=45)\end{array}$ & $\begin{array}{l}\text { Broker } \\
(n=10)\end{array}$ & $\begin{array}{l}\text { Retailer } \\
(\mathrm{n}=239)\end{array}$ & $\begin{array}{l}\text { Wholesaler } \\
(n=114)\end{array}$ & $\begin{array}{l}\text { All } \\
(n=408)\end{array}$ \\
\hline It is easy to start maize business (\% yes) & 82.2 & 60.0 & 69.9 & 53.5 & 66.4 \\
\hline Quality standards is not a major barrier to entry & 58.7 & 61.1 & 80.0 & 55.6 & 60.3 \\
\hline \multicolumn{6}{|l|}{ Most reported critical barriers to entry } \\
\hline 1. Capital & 82.2 & 85.5 & 87.2 & 82.0 & 85.2 \\
\hline 2. Business skill set & 6.70 & 10.0 & 8.8 & 9.7 & 8.8 \\
\hline \multicolumn{6}{|l|}{ Most reported threats to maize business } \\
\hline 1. Unpredictable prices & 58.9 & 50.0 & 49.6 & 57.0 & 52.7 \\
\hline 2. Limited own capital/cash flow & 50.0 & 70.0 & 53.1 & 31.1 & 47.1 \\
\hline $\begin{array}{l}\text { Food distribution programs negatively affect busi- } \\
\text { ness }\end{array}$ & 13.3 & 0.0 & 22.6 & 19.3 & 20.1 \\
\hline
\end{tabular}

Source: Author's calculations from SCP survey data (Jun/Jul 2018 and Jan/Feb 2019).

Competition was assessed by asking traders the number of their competitors of similar capacities in the same market they were located. Though not presented here for brevity, the number of competitors within the markets declined between seasons for mainly three reasons: First, the aforementioned switch between trader types. Second, some traders seasonally switch from maize trading to other in-season agricultural commodities between the main and lean season. Lastly, a few traders ceased trading in maize during the lean season due to reduced maize supplies. 


\subsubsection{Farmers' perceptions of the maize market}

We begin by discussing farmers' general perception of the market, starting with the maize production inputs market, followed by their perception of ADMARC, and finally perception of other chain actors.

\section{- Farmers' general perception of the market}

In terms of general perceptions, farmers viewed marketing systems as uncompetitive with systemic flaws at various points of input and output chains, which discourages engagement in the maize market. From the inputs side, there have been significant efforts towards increasing maize production and yields to ensure food security in Malawi since early 2000s. One of the initiatives is the Farm Input Subsidy Program (FISP), which has expanded smallholder access to production inputs (Mussa, 2015). Farmers perceived the program as poorly targeted with production inputs often distributed to not-so-needy beneficiaries thereby negatively affecting poor farm households' maize production and marketing. Non-beneficiaries of subsidized inputs viewed the input supply chain as largely inefficient and responsible for delayed supply and use of inputs leading to poor harvests. Furthermore, the inputs were deemed expensive and beyond reach of most poor farmers, resulting in escalated production costs that absorbed all profit.

From the output side, in nearly all the discussions on maize sales during the FGDs, 'distress sales' at the peak of the main marketing or lean season were mentioned whereby farmers had to sell maize to meet pressing cash needs, such as hiring 'ganyu' (labor), buying farm inputs, settling hospital bills or funeral expenses, and paying school fees. The school fee payments coincided with the peaks of the main marketing season in Malawi as the revised school calendar begins in September and the farmers forego the significant value of sales that could be realized from delayed sales up till later in the year (Dillon, 2017). Farmers perceived maize as thinly traded in Malawi with limited marketing options at their disposal. This, they argued, left the maize market vulnerable to manipulation by large traders and other middlemen to keep producer prices lower while increasing retail prices of maize. Due to the low quantities of marketable surpluses (about 20 percent of production), farmers had minimal bargaining power when negotiating for better prices with traders and village assemblers. Farmers perceived complacency in the enforcement of the minimum farm gate price and believed this contributed to low market prices. Farmers eventually sold maize at much lower prices than the minimum farm gate price - sometimes 25 or 30 percent lower during the main harvest season.

The maize marketing system was also perceived to be loosely regulated in terms of quantity and quality standards. This left farmers vulnerable to manipulation from traders and other middlemen who demanded quality maize but rarely paid any premium for quality. 'Quality' was loosely defined by cosmetic appearance of the grain in terms of size, shape, color, and whether it was a local or hybrid variety. Demand for quality maize was also seasonal and largely depended on levels of scarcity. In times of scarcity, buyers ceased to demand quality maize, unlike during times of glut.

In terms of quantity, weights and related tools varied across districts and markets. Weighing scales are more commonly used in central and southern markets but not in the northern markets where scales are frowned upon by traders. Maize was traded in 5 to $20 \mathrm{~kg}$ pails that varied between traders. Such unstandardized measures led to a perception of fraud. Traders' scales were perceived to be tampered with to record less than actual weights. Farmers therefore insisted on using their own scales whenever such opportunity arose but that again depended on levels of maize scarcity.

\section{- Farmers' perception of ADMARC}

Farmers held mixed perceptions of ADMARC's operations and engagement with farmers and other maize market players. In all FGDs, farmers spoke with nostalgia about how farming maize was great in the 1980s and early 1990s when access to and gains from selling to ADMARC were almost guaranteed. However, farmers claimed that the organization had lost its luster since then and 
tended to serve the interest of large private traders and well-connected businessmen involved in the grain trade. Farmers perceived that the corporation is corrupt with high levels of inefficiencies that impede smallholder farmers' and small traders' sales to ADMARC. Its depot clerks were widely accused of conflict of interest, whereby they individually or through proxies aggregated maize at depressed prices during the period leading up to the opening of ADMARC depots. The rent-seeking behavior of clerks at ADMARC depots also forced farmers paying between MWK500 and MWK1,000 per $50 \mathrm{~kg}$ bag just to have their maize sold.

ADMARC scales were widely perceived as inaccurate by farmers. A bag of maize that weighed $50 \mathrm{~kg}$ at a retailer's store, sometimes weighed $10 \mathrm{~kg}$ less at ADMARC. The problem was accentuated by the fact that there were sometimes few or no $50 \mathrm{~kg}$ gunny bags. Instead, 60 or $70 \mathrm{~kg}$ bags produced by Azam and other companies were widely available. Variable bag size leaves room for manipulations, as farmers risk selling more maize for less. Farmers perceived that ADMARC prices were not competitive. They noted that at the time depots opened, the market price for maize was better than ADMARC prices. Farmers also complained that the publicly announced procurement prices were not necessarily the actual prices at which maize was purchased at ADMARC depots. Perhaps this is not as surprising when the margin of well-connected assemblers, traders (many of whom are ADMARC employees during 'the day') is considered.

Despite the mixed perceptions, farmers still believed that ADMARC played a critical role in maize marketing as the buyer of last resort during main marketing season and as a supplier of maize at affordable prices during lean season. Farmers set their reserve retail prices based on ADMARC prices. in this way, ADMARC was perceived to promote competition in the maize market and reduce the possibility of exploitative behavior from private traders.

\section{- Farmers' perception of other chain actors}

In terms of other chain actors, the discussions centered on perceptions of commodity exchanges and WRSs as other marketing opportunities for maize farmers in Malawi. Despite the existence of two Malawian commodity exchanges, few farmers interviewed in the FGDs had sold maize either through the exchanges or after storing using a WRS. Findings from the national extension panel surveys revealed that no farmer had sold through these channels in the 2015/2016 and 2017/2018 main marketing seasons (Ragasa, 2019). There was a widespread perception that the commodity exchanges work in favor of private traders, large scale farmers, well-connected businessmen and that commodity exchange fees absorbed all the profits from the WRS and thus discouraged farmers with small stocks from selling through commodity exchanges. WRS also had a minimum stock requirement of $500 \mathrm{~kg}$ that many farmers could not provide. Asked about their knowledge of commodity exchanges and WRS operations, farmers showed limited knowledge. This could impede smallholder access to such market opportunities in Malawi.

\subsubsection{Traders' perceptions of the maize market}

We elicited traders' perceptions of the marketing system by probing their views on the general marketing environment, particularly about barriers to entry, degree of competition, risks involved, and maize pricing. We then narrowed down to views on large private traders, ADMARC, commodity exchanges, WRSs, and relief food distribution.

\section{- Traders' general perception of the maize market}

The Malawi maize market is quasi-competitive at lower tiers of the chain but oligopolistic at higher tiers (Sitko and Jayne, 2014). The market has many small traders, rural assemblers, and few large private traders. A majority of interviewed traders alluded to this fact and noted that there was free entry into and exit from the maize business. The maize business thrives because of sufficient volumes aggregable from villages and networked business relationships between farmers, assemblers and other middlemen. At the time of the survey, numerous makeshift stalls with weighing scales were set up along the marketing corridors by assemblers, agents of private traders 
and other middlemen to purchase maize from farmers. Yet, small traders perceive the market as highly risky and skewed in favor of a few market actors, particularly large private traders and middlemen with financial muscle involved in marketing maize. The risks of frequent price drops confine small traders to marketing maize for shorter periods. Consequently, small traders and assemblers hardly keep maize stocks for longer periods for fear of incurring storage costs that are impossible to recoup when prices drop. This discourages investment in storage of maize that could increase maize availability and stabilize prices in the lean season.

The risks are further compounded by the unpredictable policy environment, such as trade restrictions, export bans, and minimum farm gate prices set by the GoM to regulate the maize marketing environment, maize availability, and supposedly to guarantee fair producer prices. Small traders viewed the minimum farm gate prices, which are hardly implemented, as major impediment to their operations by narrowing marketing margins. Maize trade restrictions and bans were also perceived as detrimental to the maize trade. The GoM instituted a formal ban on maize exports while chiefs instituted an informal ban on green maize trade at village level in the months preceding the main harvest survey period due to the predicted maize shortages emanating from poor harvests (attributed to Fall Armyworm infestation and prolonged dry spells). The fall armyworm adversely affected yields in Africa South of the Sahara (Stokstad, 2017). Small traders perceived that export bans created artificial maize supply gluts and oligopolistic behavior among larger traders that ultimately dampened retail prices of maize. A few of those interviewed were holding stocks from the previous seasons that were bought at higher prices than they could sell at the time of the survey. This further exacerbated the fluctuations in maize supplies across seasons.

Most small traders cited inadequate capital as a major barrier to entry and the expansion of their maize marketing activities. Coupled with risks of frequent price drops, financial constraints limit traders' scope of operation and prospects of investment in storage of maize like large private traders do. Inter-regional or district maize transfer costs were also deemed high. This discouraged small traders from long distance marketing activities. The cost further escalated with many roadblocks erected along the marketing corridors, where police demanded bribes between MWK5,000 to MWK10,000 per 3-ton lorry.

As mentioned earlier, there were many small and medium scale traders and assemblers that aggregate maize and sell to larger traders in the supply chain. Large private traders are perceived to 'set prices', depressing maize prices earlier in the season to facilitate aggregation of maize at low prices and subsequently selling at high prices during the lean season. The sequence of maize harvesting, which begins earlier in southern districts and later in northern districts, works to the advantage of large traders with financial and logistical resources to aggregate and move maize from supply surplus to deficit regions. Ironically, despite the small traders' negative perception of large private traders, they opined that GoM should expand the maize trading space to allow for large traders to compete and coexist with ADMARC. This proposition and its perceived reasons are expounded in the following discussion.

\section{- Traders' perception of ADMARC}

Several major issues were raised about the corporation as follows: First, ADMARC receives funding in late June/July after the National Budget is approved. Slow disbursement of funds further delays procurement until August or September. By this time, most small traders have sold stocks to large traders and other middlemen (usually well-connected private traders) who later supply ADMARC. Second, many traders complained of the winding queues at ADMARC depots and rent-seeking behaviors by clerks that discourage small traders from supplying to ADMARC, an observation also made by Jayne et al (2010). Clerks were accused of demanding bribes between MWK500 and MWK1,000 per $50 \mathrm{~kg}$ bag supplied. Third, many traders perceived that ADMARC weighing scales were faulty or inaccurate and made them lose up to $10 \mathrm{~kg}$ for every $50 \mathrm{~kg}$ bag of maize. Assemblers reported that a $50 \mathrm{~kg}$ bag of dry maize as weighed by them or at retailers' stalls was weighed at 5$10 \mathrm{kgs}$ less at ADMARC depots. This could explain why few traders sold to ADMARC as shown in 
the following discussions on sales activities of traders. Fourth, small traders were clearly confused about the timing of ADMARC activities in terms of opening and closing times of depots, which caused the winding queues. Fifth, many of the traders interviewed perceived that stocks from ADMARC were of inferior quality. This is surprising given that ADMARC depots only buy maize with low moisture content. Lastly, conflict of interest was widely perceived with accusations of insider trading, whereby ADMARC employees supplied ADMARC through other traders informally contracted to aggregate maize on their behalf. During the survey, several middlemen with 3 or 5 -ton lorries were observed buying maize from smaller traders to sell at the closest ADMARC depots once opened. Many traders therefore recommended that GoM should allow large private traders to compete with ADMARC to increase efficiency and gains in maize marketing.

\section{- Traders' perception of other chain actors}

Malawi is one of the few African countries with two commodity exchanges (ACE and AHCX - now AHL Group). The exchanges also engage in maize marketing. Ordinarily, the WRS and commodity exchanges are distinct in operations (CTA and EAGC, 2013; Mezui et al., 2013) but in Malawi they have an intricately complex relationship as the exchanges are also involved in the WRS. Through the WRS, traders can store commodities at certified warehouses and use the receipt issued as collateral in accessing credit. This is usually done at a fee charged by warehouses for storage services. Small traders saw little benefit in commodity exchanges and the WRS, owing to the minimum tonnage requirement and prohibitive fees. Less than one-third of maize traders were aware that they could sell maize through a commodity exchange and only one-fifth of these had ever sold maize to either of Malawi's commodity exchanges. None of the small traders sold through commodity exchanges during the immediate marketing season.

Agriculture is predominantly rain-fed in Malawi. Frequent prolonged dry spells and pest infestations lead to erratic production (FEWS NET, 2018). Many poor households, largely SHFs, experience prolonged periods of hunger that often necessitate interventions by GoM, WFP and NGOs for food distribution and safety net programs such as cash or food for work. Most of the traders singled out food (maize) for work programs as detrimental to their businesses as the programs depress prices for longer periods in many markets. A few traders viewed the programs as beneficial because some poor households resell the distributed maize to traders at lower prices. The interviewed traders however were in favor of other interventions such as cash for work since it stimulated rural economy and expanded maize demand during hunger seasons.

\subsection{Conduct of maize market}

This section presents findings on the conduct of maize market in terms of marketing strategies of traders; inter-seasonal switch across trader types; maize volumes seasonality by marketing channels; inequality in sales revenue; access to marketing information; and price setting mechanisms.

\subsubsection{Traders' marketing strategies}

Table 5 provides details on marketing strategies of traders such as membership in marketing associations and experiences with sales or purchases contracts and tenders. Value propositions that assessed traders' risk preferences are also listed in Table 5. Less than five percent of the sampled small traders were members of any maize marketing association. Surprisingly, none of the ten brokers belonged to any association.

Traders were asked whether they had any contracts or binding agreements to purchase or sell maize. About 20 percent of the traders were contracted for supply of maize at a price that was mainly determined by the suppliers ( 71 percent). In terms of sales, about 15 percent of traders were contracted to supply maize at a price mainly determined by the buyers ( 79 percent). The study noted elements of exploitative, predatory, and tactful relationships among traders particularly under the contractual arrangements. All contractual arrangements were verbal, which could explain the 
widespread pessimistic view of contracts by many traders that had experienced default on the verbal contracts.

Table 5: Marketing strategies of maize traders (\% yes)

\begin{tabular}{|c|c|c|c|c|c|}
\hline Variable & $\begin{array}{c}\text { Assembler } \\
(n=45)\end{array}$ & $\begin{array}{c}\text { Broker/agent } \\
(n=10)\end{array}$ & $\begin{array}{l}\text { Retailer } \\
(n=239)\end{array}$ & $\begin{array}{c}\text { Wholesaler } \\
(n=114)\end{array}$ & $\begin{array}{c}\text { All } \\
(408)\end{array}$ \\
\hline Member of maize marketing association & 2.2 & 0.0 & 0.8 & 5.3 & 2.2 \\
\hline Contracted for purchases & 22.2 & 20.0 & 20.5 & 19.3 & 20.3 \\
\hline Supplier sets price in the purchases contract & 80.0 & 0.0 & 76.5 & 61.4 & 71.1 \\
\hline Contracted for sales & 15.5 & 30.0 & 12.9 & 18.4 & 15.2 \\
\hline Trader sets price in the sales contract & 78.6 & 33.3 & 87.1 & 73.8 & 79.0 \\
\hline Experience with competitive tenders & 11.1 & 20.0 & 11.7 & 20.2 & 14.2 \\
\hline Stored maize in anticipation of higher prices & 37.8 & 20.0 & 30.1 & 45.6 & 35.1 \\
\hline Trader stocking level depend on competitors & 35.6 & 25.0 & 29.7 & 31.6 & 30.8 \\
\hline Stocking maize for more than 3 months is risky & 75.6 & 85.0 & 74.5 & 71.9 & 74.1 \\
\hline Stocking maize for less than 3 months is advantageous & 93.3 & 90.0 & 97.3 & 96.9 & 96.6 \\
\hline
\end{tabular}

Source: Author's calculations from SCP survey data (Jun/Jul 2018 and Jan/Feb 2019).

A few traders had experience with competitive tenders. During the survey period, NFRA contracted AHCX to procure $17,000 \mathrm{MT}$ of maize to replenish the strategic grain reserve. Surprisingly, only one trader in the North reported indirectly supplying to AHCX through a large trader. Only about 35 percent of the traders interviewed stored maize in anticipation of higher prices, with the greatest proportion of storers being wholesalers ( 46 percent) followed by assemblers ( 38 percent). Brokers stored very little because they were acting for other larger traders and working on a commission basis.

Traders cited quality problems as reason for not sourcing maize from ADMARC. However, traders sold very little maize to or through certified warehouses issuing warehouse receipts or extension commodity exchanges mainly because of the warehouses' stringent quality requirements that lack a price premium for quality. Furthermore, commodity exchanges have a minimum quantity requirement of $0,5 \mathrm{MT}$, which many small traders cannot supply in one go. In addition, many small traders cannot afford the warehousing charges for grading, bagging and storage (Baulch et al., 2018a). Liquidity constrained small traders avoid sales through the warehouses as payments are often delayed, and the warehousing charges are high. Traders did also not buy from farmers associations because they demanded higher prices than alternative sources. Overall, the findings point to very limited access to structured markets in Malawi that could facilitate planning of maize production and marketing.

On a scale of 1 (strongly agree) to 4 (strongly disagree), traders were asked to respond to the value proposition that their stocking levels depended on stocking levels of competitors. Only about 31 percent affirmed that their stocking levels depended on those of competitors. Asked about the risk of stocking maize for more than three months from time of purchase to sale on a scale of 1 (no risk) to 4 (high risk), most of the traders viewed it as risky (74 percent). This is attributed to the high maize price volatility in Malawi mentioned earlier and results in an unpredictable marketing environment in which many traders will not engage in warehousing for long periods. The traders were then asked if they thought stocking maize for less than three months was advantageous on a scale of 1 (no advantage) to 4 (high advantage). Most traders viewed this as advantageous mainly in terms of mitigating against probable losses from price falls while stocking (93 percent). 


\subsubsection{Switches between trader types across seasons}

As earlier mentioned, cyclical rural-urban trade reversals across agricultural seasons with many traders reporting sales to urban markets in the main harvest season and purchases (by rural traders) from urban markets during the lean season. This also led to seasonal switch between trader types as shown in Figure 4. Forty assemblers and 39 wholesalers switched to retailing maize in the lean season whereas 9 retailers switched to wholesaling. Three of the wholesalers also switched to becoming agents of large national/regional maize traders, aggregating maize from farmers for a commission. Such shifts were attributed to limited financial capacity to aggregate, bag, truck, fumigate, and store large quantities. The brokers would ordinarily get advances for aggregation, which they used to buy maize for their businesses as well as for the large traders.

Figure 4: Seasonal switches between trader types

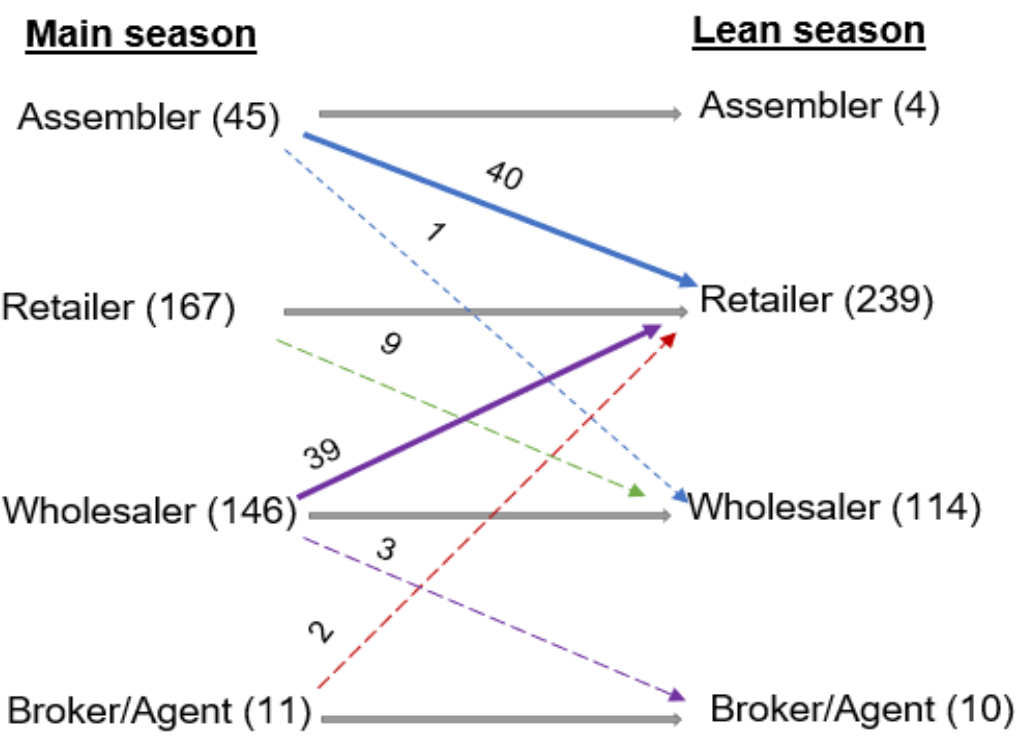

Source: Authors' construction from IFPRI Survey Data (April-June 2018).

\subsubsection{Seasonality of maize volumes}

Figure 5 presents a summary of quantities purchased or sold by traders during the 12 months preceding the interviews. Larger quantities of maize were traded during the third quarter of the year than in the first and second quarter, particularly during October. This is plausible for two reasons. First, there was less demand for new maize from the main market season because of its high moisture content. In addition, arbitrage was limited in the second quarter because of increased maize supplies in the market that depressed prices. Second, maize trade is seasonal among many traders whereby intense trade is observed in the main harvest season but less in the lean season due to reduced maize supply and capital constraints. 
Figure 5: Seasonality of maize volumes traded (MT/month)
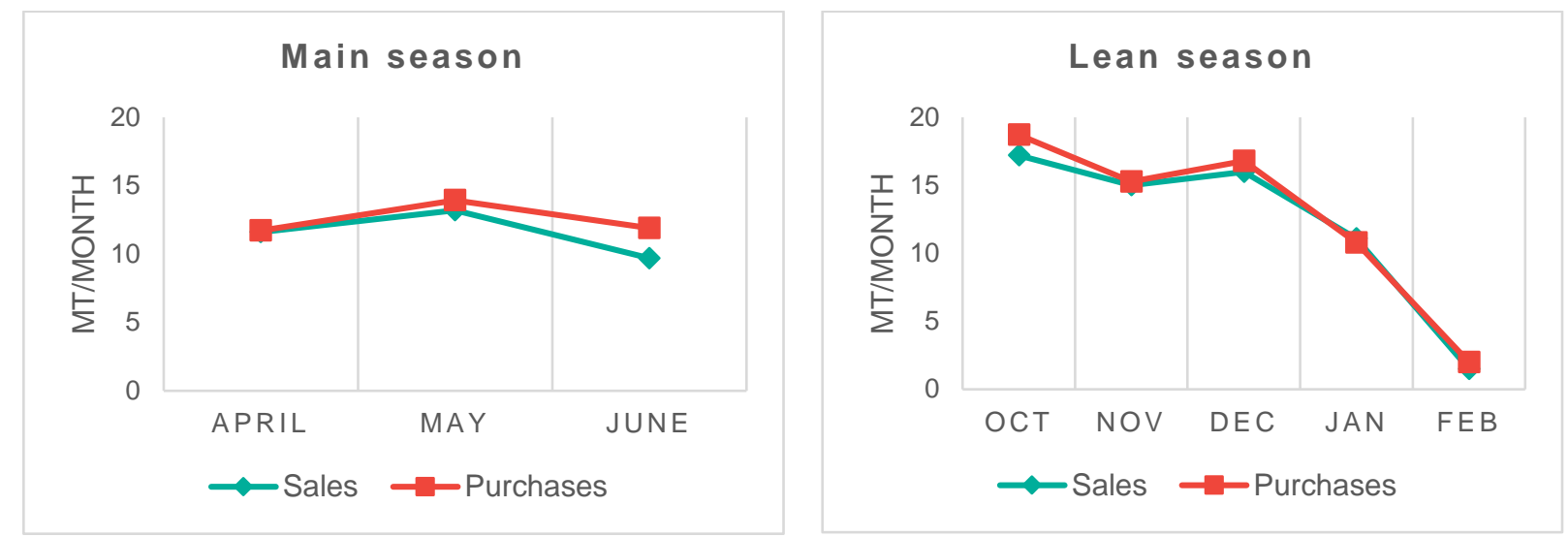

Source: Author's calculations from SCP survey data (Jun/Jul 2018 and Jan/Feb 2019).

\subsubsection{Maize volumes traded through various channels}

Table 6 presents a seasonal comparison of traded maize volumes through various marketing channels. In terms of purchases, the greatest proportion of maize purchased was from small-scale farmers (50 percent) followed by other traders (37 percent) during the main harvest season. In contrast, in the lean season, the greatest proportion of purchases was from other traders (56 percent), followed by small-scale farmers (30 percent). Interestingly, five of the ten brokers sold maize on behalf of large farmers. Purchases from other suppliers such as farmers associations, certified warehouses (operated by commodity exchanges), and ADMARC were minimal (below 5 percent) in both seasons. Notably, purchases from and sales to ADMARC were only reported during the lean season. Overall, the proportion of purchases from different suppliers was statistically significant between the main harvest and lean seasons (Table A.2 in the Appendix).

In terms of sales, Table 6 shows a similar pattern whereby the greatest proportion of sales were made to individual consumers (59 percent in the main season and 59 percent in the lean season), followed by other traders ( 16 percent and 18 percent respectively). The majority of the individuals from rural areas were small-scale maize farmers, who are mostly net buyers of maize. There are three types of net buyers: (1) those who do not sell any of the harvested stocks but purchase for own consumption when stocks are depleted in the lean season; (2) farmers who sell most of the harvest at lower prices early in the season to meet pressing cash needs (i.e. school fees, medical costs, other emergencies) but buy later at higher prices during the peak of lean season; (3) farmers who sell maize early in the season to repay debts to money lenders and village savings and credit groups in what is commonly known as 'distress surplus'. Overall, there was a statistically significant difference in proportions sold to different buyers in the two seasons. The quantities sold to buyers were higher in the main harvest season than in the lean season.

Maize is mainly produced by small-scale farmers largely under rain-fed production system. This results in supply seasonality with greater supply in the main harvest season but less supply in the lean season.

Interestingly, despite the large network of ADMARC depots, certified warehouses, and widespread existence of Farmers' Associations in Malawi, only a few of the traders made small purchases from or sold to these outlets during both seasons. Further, no sales to ADMARC were reported during the main harvest season for reasons outlined in the previous section. 
Table 6: Maize purchases and sales in the main marketing and lean season

\begin{tabular}{|c|c|c|c|c|c|c|c|c|c|c|}
\hline \multirow[b]{2}{*}{ Variable } & \multicolumn{5}{|c|}{ Main harvest season (Apr-Jul 2018) } & \multicolumn{5}{|c|}{ Lean season (Oct 2018-Feb 2019) } \\
\hline & $\begin{array}{l}\text { Assembler } \\
\quad(n=45)\end{array}$ & $\begin{array}{l}\text { Broker/agent } \\
\quad(n=10)\end{array}$ & $\begin{array}{l}\text { Retailer } \\
(n=239)\end{array}$ & $\begin{array}{l}\text { Wholesaler } \\
(n=114)\end{array}$ & $\begin{array}{c}\text { All } \\
(408)\end{array}$ & $\begin{array}{l}\text { Assembler } \\
(n=45)\end{array}$ & $\begin{array}{l}\text { Broker/agent } \\
\quad(n=10)\end{array}$ & $\begin{array}{l}\text { Retailer } \\
(n=239)\end{array}$ & $\begin{array}{l}\text { Wholesaler } \\
(n=114)\end{array}$ & $\begin{array}{l}\text { All } \\
(408)\end{array}$ \\
\hline \multicolumn{11}{|l|}{ Purchases } \\
\hline \multicolumn{11}{|l|}{$\begin{array}{l}\text { Share of maize pur- } \\
\text { chases }\end{array}$} \\
\hline Small scale farmers (\%) & 65.4 & 68.0 & 46.2 & 51.1 & 50.3 & 34.9 & 46.0 & 26.6 & 34.3 & 30.2 \\
\hline Large farmers (\%) & 2.1 & 1.4 & 1.5 & 2.3 & 1.8 & 5.5 & 50.2 & 10.0 & 12.1 & 11.1 \\
\hline Other traders $(\%)$ & 23.6 & 3.9 & 44.8 & 30.5 & 37.5 & 56.2 & 2.4 & 61.6 & 49.8 & 56.2 \\
\hline ADMARC (\%) & 0.0 & 0.0 & 0.0 & 0.0 & 0.0 & 1.1 & 1.4 & 0.4 & 2.1 & 1.0 \\
\hline $\begin{array}{l}\text { Certified warehouses } \\
\text { (\%) }\end{array}$ & 0.1 & 0.1 & 0.0 & 0.0 & 0.0 & 0.0 & 0.0 & 0.0 & 0.0 & 0.0 \\
\hline \multicolumn{11}{|l|}{ Sales } \\
\hline \multicolumn{11}{|l|}{ Share of maize sales } \\
\hline Individuals (\%) & 60.3 & 20.0 & 72.1 & 32.0 & 58.3 & 61.2 & 29.6 & 66.8 & 45.6 & 59.3 \\
\hline Retail stores (\%) & 1.2 & 0.0 & 1.6 & 2.4 & 1.7 & 0.0 & 0.0 & 0.2 & 0.3 & 0.2 \\
\hline Processors (\%) & 0.0 & 0.0 & 2.7 & 3.5 & 2.6 & 2.6 & 2.4 & 2.3 & 1.5 & 2.1 \\
\hline Other traders (\%) & 21.4 & 46.7 & 13.2 & 36.5 & 21.5 & 15.8 & 51.6 & 10.4 & 31.5 & 17.9 \\
\hline ADMARC (\%) & 0.0 & 0.0 & 0.0 & 0.0 & 0.0 & 0.1 & 0.4 & 0.3 & 0.1 & 0.2 \\
\hline Warehouses (\%) & 0.0 & 3.3 & 0.5 & 1.3 & 0.8 & 0.0 & 2.0 & 0.4 & 1.7 & 0.8 \\
\hline
\end{tabular}

Source: Author's calculations from SCP survey data (Jun/Jul 2018 and Jan/Feb 2019). 


\subsubsection{Inequality in trader sales revenues in the maize market}

Distribution of sales revenues among traders of similar capacities is one of the pointers of market conduct. Widespread inequality characterizes imperfect markets with restricted flow of market information on prices or sources of supplies to maximize profits. To measure sales revenue inequality, we used the Gini coefficient, ranging from 0 to $1(0=$ perfect equality, $1=$ perfect inequality). The coefficient was derived from Lorenz curves, which plotted the cumulative proportion of sales revenue against the cumulative proportion of the traders when they were sorted from the poorest to the richest (see Figure 6). Figure 6 shows inequality during the main harvest season and lean season. Parker and Connor (1979) recommend that Gini coefficients that are less than or equal to 0.4 indicate a purely competitive market structure, whilst coefficients above 0.4 show low competition. Gini coefficients observed in this study show that the market is not driven by pure competition. Nevertheless, wholesalers are observed to be relatively more competitive in comparison to other trader types.

Figure 6: Lorenz curve of sales revenue during the main harvest and lean seasons 2018

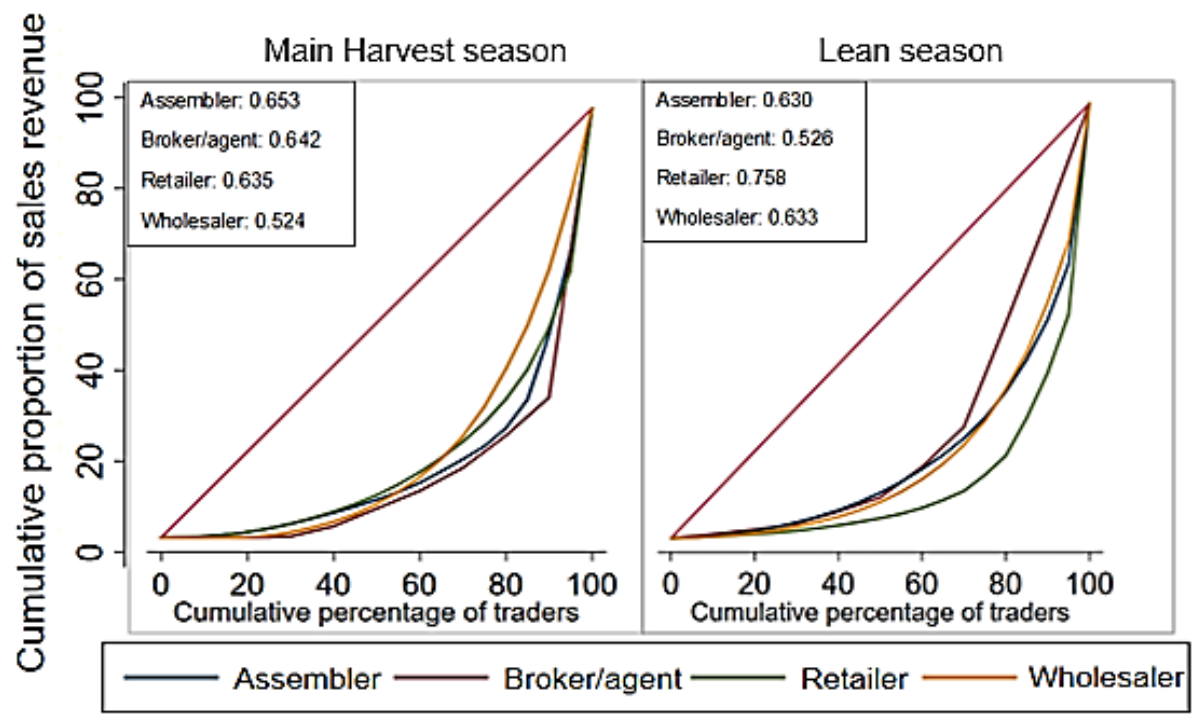

Source: Author's calculations from SCP survey data (Jun/Jul 2018 and Jan/Feb 2019).

Overall, inequality of sales revenue was higher in the lean season $(0.68)$ than in the main harvest season (0.67) (Table 7). There were positive and negative differences in inequality across different trader types between the main harvest and lean seasons. Between the main harvest and lean seasons, inequality reduced by 3 percent and 19 percent among assemblers and brokers, respectively while inequality rose by 19 percent and 21 percent among retailers and wholesalers, respectively.

Table 7: Inequality of sales revenue, measured using Gini coefficients

\begin{tabular}{lccc} 
& Main harvest season & Lean season & Difference \\
\hline Assembler & 0.65 & 0.63 & 0.02 \\
Broker/agent & 0.64 & 0.53 & 0.12 \\
Retailer & 0.64 & 0.76 & -0.12 \\
Wholesaler & 0.52 & 0.63 & -0.11 \\
Overall & 0.67 & 0.68 & -0.013 \\
\hline
\end{tabular}

Source: Author's calculations from SCP survey data (Jun/Jul 2018 and Jan/Feb 2019). 
In Table 8 we decompose inequalities in sales revenue into three components: between the main harvest and lean seasons; within trader types and between urban and rural areas. Although the Gini coefficient has desirable properties of mean and population size independence, it cannot be decomposed exactly like other measures of inequality. We therefore used Theil's T index, a generalized entropy measure, for this decomposition which assumes alpha $=1$. The index ranges between 1 and infinity, where zero value shows equal distribution while higher values show higher levels of inequality. Overall, within-inequality was greater than between-inequality for season, trader type, and urban/rural location. Income distribution was similar between urban and rural traders. Nonetheless, there were statistically significant income differences among traders in the poorest quintile between the main harvest and lean seasons.

Table 8: Decomposition of sales revenue inequality

\begin{tabular}{lccc} 
& Theil's T & Between & Within \\
Main harvest versus Lean season & & $0.11(10.3)$ & $0.96(89.7)$ \\
Trader types & 1.07 & $0.14(13.0)$ & $0.93(86.9)$ \\
Urban versus Rural & & $0.00(0.0)$ & $1.06(100.0)$ \\
\hline
\end{tabular}

Source: Author's calculations from SCP survey data (Jun/Jul 2018 and Jan/Feb 2019). Note: Percentages of income variations across categories in parentheses.

\subsubsection{Access to marketing information}

Market price information plays an important role in facilitating spatial market integration and price adjustments thus facilitating spatial and time arbitrage. In an ideal or perfect market, information freely flows to aid in trade decisions. However, markets are largely imperfect, especially in developing countries and this was also observed in this study. Despite numerous public information sources, just 5 percent of traders used publicly available information to set prices during the main harvest season (Table 9). Public sources included print and digital media as well as public announcements, such as for minimum farm gate prices. Surprisingly, none of the sampled traders relied on the minimum farm gate price.

A greater proportion of traders relied on personal knowledge of the market to set maize prices (Table 9). A negligible proportion of traders relied on prices from warehouse operators to set their prices. This is plausible, given the limited access to such structured markets in Malawi. Equally, a small proportion of traders relied on ADMARC pricing particularly during main harvest season (0.5 percent). Many of the sampled traders intimated that the announced ADMARC prices were not necessarily the prices offered at the depots.

Table 9: Sources of pricing information and their usefulness

\begin{tabular}{|c|c|c|c|c|}
\hline \multirow[b]{2}{*}{ Source of price information } & \multicolumn{2}{|c|}{ Main harvest season } & \multicolumn{2}{|c|}{ Lean season } \\
\hline & $\%$ used & $\%$ Found it useful & $\%$ used & $\%$ Found it useful \\
\hline Publicly available information & 4.7 & 78.9 & 14.2 & 67.2 \\
\hline Personal knowledge of the market & 96.3 & 96.4 & 97.5 & 98.2 \\
\hline Price set by the buyer you sold to & 10.8 & 72.7 & 6.6 & 66.7 \\
\hline Warehouse operators & 0.0 & 0.0 & 0.5 & 0.0 \\
\hline ADMARC & 0.5 & 50.0 & 19.1 & 61.5 \\
\hline
\end{tabular}

Source: Author's calculations from SCP survey data (Jun/Jul 2018 and Jan/Feb 2019). 


\subsubsection{Price setting mechanism}

During the baseline survey, pricing was one of the most cited problems. Therefore, we explicitly asked traders about their price setting mechanism during the lean season survey. Table 10 presents the reported price setting mechanisms by frequency of traders and selling price per $\mathrm{kg}$ of maize. Our findings show that the majority of traders used cost-plus pricing (51 percent) followed by collusion (27 percent) with other traders to set prices.

Cost-plus (or markup) pricing refers to prices set based on purchases and marketing costs incurred and desired profit. There was little evidence of predatory pricing or pricing based on quality of maize. In contrast to the two most reported pricing mechanisms, the corresponding selling prices show that demand driven pricing fetched the highest prices.

Table 10: Price setting mechanisms

\begin{tabular}{|c|c|c|c|c|}
\hline Pricing mechanism & Frequency & Percent & Highest price $^{a}$ & Lowest price $^{\mathrm{a}}$ \\
\hline Collusion & 85.0 & 27.2 & 196.1 & 152.6 \\
\hline Cost-plus pricing & 159.0 & 51.0 & 201.2 & 153.9 \\
\hline Demand driven & 19.0 & 6.1 & 333.2 & 210.0 \\
\hline Follow leader & 43.0 & 13.8 & 164.2 & 130.1 \\
\hline Predatory & 3.0 & 1.0 & 170.0 & 126.7 \\
\hline Based on quality & 3.0 & 1.0 & 151.7 & 136.7 \\
\hline
\end{tabular}

Source: Author's calculations from SCP survey data (Jan/Feb 2019).

Note: $\mathrm{N}=312$, Question was asked only during the follow up survey in the lean season, ${ }^{\text {a }}$ selling price.

Central and northern Malawi are maize surplus regions, while the South is a deficit region. Therefore, it could be argued that price setting mechanism varies regionally. Though, not shown in Table 10 , our analysis shows that cost-plus pricing is the most common price setting mechanism in all regions (North $=63$ percent; Center $=44$ percent; South $=57$ percent) followed by collusion then price leadership. Interestingly, collusion and price leadership were more common in central markets than in the North and South.

\subsubsection{Maize trade financing}

In an environment where structured trading is limited and cash payments are demanded for most transactions, financial constraints stifle spatial arbitrage particularly when transfer costs are high. Many traders cited financial constraints as a major limitation to maize trading. More than 80 percent of sampled traders relied on own funds to finance the business during the main harvest and lean seasons (Table 11). As mentioned earlier, this is one of the reasons for switches in trader types between seasons, especially among financially constrained small traders and commission agents. This partially explains the limited market reach and access to structured markets with higher quantity requirements. Access to credit remains limited among maize traders. 
Table 11: Maize trade financing

\begin{tabular}{|c|c|c|c|c|c|}
\hline Variable & $\begin{array}{c}\text { Assembler } \\
(\mathrm{n}=45)\end{array}$ & $\begin{array}{c}\text { Broker/agent } \\
(n=10)\end{array}$ & $\begin{array}{l}\text { Retailer } \\
(n=239)\end{array}$ & $\begin{array}{c}\text { Wholesaler } \\
(n=114)\end{array}$ & $\begin{array}{c}\text { All } \\
(408)\end{array}$ \\
\hline \multicolumn{6}{|c|}{ Panel A: Harvest season } \\
\hline Own funds only & 82.2 & 50.0 & 83.3 & 93.9 & 85.3 \\
\hline Borrowed funds only & 8.9 & 30.0 & 6.7 & 2.6 & 6.4 \\
\hline Owned and borrowed & 4.4 & 10.0 & 9.6 & 3.5 & 7.4 \\
\hline Other & 4.4 & 10.0 & 0.4 & 0.0 & 0.9 \\
\hline \multicolumn{6}{|l|}{ Panel B: Lean season } \\
\hline Own funds only & 84.4 & 80.0 & 82.0 & 85.9 & 83.3 \\
\hline Borrowed funds only & 4.4 & 20.0 & 6.7 & 6.1 & 6.6 \\
\hline Owned and borrowed & 11.1 & 0.0 & 10.9 & 7.0 & 9.6 \\
\hline Other & 0.0 & 0.0 & 0.4 & 0.9 & 0.5 \\
\hline
\end{tabular}

Source: Author's calculations from SCP survey data (Jun/Jul 2018 and Jan/Feb 2019).

\subsection{Performance of maize market}

This section discusses the indicators of market performance. We begin by discussing maize volumes and price dynamics across seasons, followed by marketing activities and their related costs. We then describe our findings on the net margins realized by traders and finally the temporal (price seasonality and volatility) and spatial (spatial market integration) efficiencies of the maize market.

\subsubsection{Maize volumes and price dynamics}

Table 12 presents a summary of maize purchases and sales in the main harvest and lean season as well as price information in terms of differences, pricing mechanism, and changes. There were more maize purchases during the lean season than during the main harvest marketing season. The study showed that the difference in stocks purchased was statistically significant between both seasons. Similarly, the average single largest sale in the lean season was higher than in the main season for most traders. Most traders delayed purchases and sales to the tail-end of the main season to minimize warehousing costs and risks of aflatoxin exposure or weight losses from reduced moisture content of maize bought at the onset of the main season.

In terms of prices, both buying and selling prices changed significantly in the three years preceding the survey particularly in the main harvest season. Malawi's maize price volatility is one of the highest in eastern and southern Africa region (Minot, 2014). High price seasonality is caused by increased supplies to the market during the main harvest and reduced supplies during the lean season. This is evidenced by the substantial price range of MWK35,000/MT of maize. Price ranges were higher among retailers and wholesalers than other trader types.

Traders were asked what they considered to be the level of price premiums needed to break even if they were to: (i) buy and sell maize without warehousing; and (ii) vis-à-vis warehousing maize for three months. We observed significant differences in acceptable price premiums, which points to underlying marketing risks in warehousing maize. The majority of the sampled traders were unwilling to store maize for more than three months due to unpredictable prices. Maize prices changed more frequently on a monthly/seasonal basis than on a weekly/daily basis. 
Table 12: Maize trade and pricing

\begin{tabular}{|c|c|c|c|c|c|}
\hline Variable & $\begin{array}{l}\text { Assembler } \\
(\mathrm{n}=45)\end{array}$ & $\begin{array}{l}\text { Broker/agent } \\
\quad(n=10)\end{array}$ & $\begin{array}{l}\text { Retailer } \\
(n=239)\end{array}$ & $\begin{array}{l}\text { Wholesaler } \\
(n=114)\end{array}$ & $\begin{array}{c}\text { All } \\
(408)\end{array}$ \\
\hline \multicolumn{6}{|l|}{ Purchases and sales } \\
\hline Purchases in main season (MT) & 19.3 & 45.1 & 25.9 & 67.1 & 37.2 \\
\hline Purchases in the lean season (MT) & 46.4 & 77.8 & 42.9 & 113.0 & 63.7 \\
\hline Largest sale in main season (MT) & 1.8 & 20.3 & 2.3 & 9.7 & 4.7 \\
\hline Largest sale in lean season (MT) & 3.4 & 13.1 & 4.8 & 21.8 & 9.6 \\
\hline \multicolumn{6}{|l|}{ Price analysis } \\
\hline $\begin{array}{l}\text { Buying price changed significantly } \\
\text { of the last } 3 \text { years (\%yes) }\end{array}$ & 82.2 & 60.0 & 69.0 & 66.7 & 69.6 \\
\hline $\begin{array}{l}\text { Selling price changed significantly } \\
\text { of the last } 3 \text { years (\%yes) }\end{array}$ & 77.8 & 70.0 & 70.3 & 64.9 & 69.6 \\
\hline $\begin{array}{l}\text { Prices change more frequently in } \\
\text { the harvest season (\%yes) }\end{array}$ & 60.0 & 50.0 & 60.7 & 62.3 & 60.8 \\
\hline Price range in ' $000^{\prime} / \mathrm{MT}^{\mathrm{a}}$ & $\begin{array}{l}22.4 \\
(20.3)\end{array}$ & $\begin{array}{l}25.0 \\
(19.9)\end{array}$ & $\begin{array}{c}36.9 \\
(136.1)\end{array}$ & $\begin{array}{c}37.9 \\
(147.7)\end{array}$ & $\begin{array}{c}35.3 \\
(130.3)\end{array}$ \\
\hline \multicolumn{6}{|l|}{ Price premium to add to... } \\
\hline $\begin{array}{l}\text {...buying price to breakeven when } \\
\text { trader does not store }{ }^{\mathrm{b}}\end{array}$ & $\begin{array}{l}200.8 \\
(201.3)\end{array}$ & $\begin{array}{c}150.7 \\
(122.6)\end{array}$ & $\begin{array}{c}192.6 \\
(175.8)\end{array}$ & $\begin{array}{c}193.6 \\
(225.9)\end{array}$ & $\begin{array}{c}192.7 \\
(192.6)\end{array}$ \\
\hline $\begin{array}{l}\text {...buying price to breakeven when } \\
\text { trader stores maize for } 3 \text { months }\end{array}$ & $\begin{array}{c}486.6 \\
(418.5)\end{array}$ & $\begin{array}{c}315.1 \\
(337.6)\end{array}$ & $\begin{array}{c}445.6 \\
(411.3)\end{array}$ & $\begin{array}{c}450.9 \\
(404.9)\end{array}$ & $\begin{array}{c}448.7 \\
(408.8)\end{array}$ \\
\hline \multicolumn{6}{|l|}{ Frequency of price changes } \\
\hline Seasonally & 31.1 & 10.0 & 33.5 & 26.3 & 30.6 \\
\hline Monthly & 55.6 & 20.0 & 48.5 & 44.7 & 47.6 \\
\hline Weekly & 8.9 & 50.0 & 15.9 & 24.6 & 18.4 \\
\hline Daily & 4.4 & 20.0 & 2.1 & 4.4 & 3.4 \\
\hline
\end{tabular}

Source: Author's calculations from SCP survey data (Jun/Jul 2018 and Jan/Feb 2019).

Note: ${ }^{a}$, range refers to difference between the highest and lowest price, ${ }^{b}$, standard deviations in parentheses.

\subsubsection{Maize marketing activities and costs}

\section{- Quality improvement activities}

In terms of quality improvement, Table 13 summarizes the activities undertaken by traders prior to selling maize. There was not much investment in quality improvement activities beyond weighing and bagging of maize during both main and lean seasons. Traders rarely carried out sorting or grading. This is plausible for the following reasons: First, there are either no or only very small price premiums for quality maize. Second, there is a lack of quality standardization in the maize market. Third, 'quality' demands are only more pronounced during the main harvest season, when supplies are plentiful, and less during the lean season, when maize is scarcer and competition among traders is stiff. Lastly, the limited financial resources of traders also limited investment in drying and grading equipment. Drying was done more in the main season than in lean season because of high moisture content of the 'new' maize purchased during the main season. 
Table 13: Quality improvement activities (\% yes)

\begin{tabular}{|c|c|c|c|c|c|}
\hline Variable & $\begin{array}{l}\text { Assembler } \\
(\mathrm{n}=45)\end{array}$ & $\begin{array}{l}\text { Broker/agent } \\
(n=10)\end{array}$ & $\begin{array}{l}\text { Retailer } \\
(n=239)\end{array}$ & $\begin{array}{l}\text { Wholesaler } \\
(n=114)\end{array}$ & $\begin{array}{c}\text { All } \\
(408)\end{array}$ \\
\hline \multicolumn{6}{|l|}{ Panel A: Main harvest season } \\
\hline \multicolumn{6}{|l|}{$\begin{array}{l}\text { To meet buyer requirements, } \\
\text { trader... }\end{array}$} \\
\hline weighed and bagged & 62.2 & 60.0 & 71.5 & 64.0 & 68.1 \\
\hline removed foreign matter & 28.9 & 10.0 & 30.1 & 17.5 & 25.9 \\
\hline dried maize & 33.3 & 0.0 & 23.9 & 14.0 & 21.5 \\
\hline removed live pests & 22.2 & 10.0 & 22.1 & 20.2 & 21.3 \\
\hline removed discolored grains & 15.6 & 0.0 & 21.3 & 18.4 & 19.4 \\
\hline sorted/graded & 11.1 & 10.0 & 13.4 & 14.9 & 13.5 \\
\hline \multicolumn{6}{|l|}{ Panel B: Lean season } \\
\hline \multicolumn{6}{|l|}{$\begin{array}{l}\text { To meet buyer requirements, } \\
\text { trader... }\end{array}$} \\
\hline weighed and bagged & 71.1 & 70.0 & 64.8 & 75.4 & 68.6 \\
\hline removed foreign matter & 13.3 & 20.0 & 25.5 & 27.2 & 24.5 \\
\hline dried maize & 4.4 & 0.0 & 2.1 & 4.4 & 2.9 \\
\hline removed live pests & 35.6 & 40.0 & 35.9 & 37.7 & 36.5 \\
\hline removed discolored grains & 6.7 & 20.0 & 16.7 & 27.2 & 18.6 \\
\hline sorted/graded & 6.7 & 0.0 & 7.5 & 6.1 & 6.9 \\
\hline
\end{tabular}

Source: Author's calculations from SCP survey data (Jun/Jul 2018 and Jan/Feb 2019).

\section{Marketing costs}

Of the eight marketing costs, the physical costs of transporting, bagging, loading and off-loading maize constituted a significant proportion (about 90 percent) of the total monthly marketing cost (Table 14). The high costs of labor for bagging and loading/off-loading is due to limited investment in equipment to reduce manual labor and enhance efficiency and lower costs. Other costs were minimal as also evidenced by the preceding discussion on quality improvement. 
Table 14: Average monthly maize marketing costs (MWK/kg)

\begin{tabular}{lccccc} 
Costs & $\begin{array}{c}\text { Assembler } \\
(\mathbf{n}=\mathbf{4 5})\end{array}$ & $\begin{array}{c}\text { Broker/agent } \\
(\mathbf{n}=10)\end{array}$ & $\begin{array}{c}\text { Retailer } \\
(\mathbf{n}=239)\end{array}$ & $\begin{array}{c}\text { Wholesaler } \\
(\mathbf{n}=114)\end{array}$ & $\begin{array}{c}\text { All } \\
(\mathbf{4 0 8})\end{array}$ \\
\hline Fixed costs (labor cost) & $6,711.1$ & $57,000.0$ & $5,198.7$ & $32,986.8$ & $14,399.5$ \\
Variable costs & $38,262.2$ & $109,000.0$ & $29,076.4$ & $160,201.1$ & $68,686.3$ \\
$\begin{array}{l}\text { Transportation (purchase to final } \\
\text { market) }\end{array}$ & $9,043.9$ & $4,581.3$ & $13,425.9$ & $77,105.5$ & $45,186.1$ \\
Bagging & $3,895.6$ & $9,700.0$ & $7,774.8$ & $37,717.5$ & $15,760.5$ \\
Loading and off-loading & $3,184.4$ & $10,400.0$ & $4,625.5$ & $13,841.3$ & $7,183.2$ \\
Storage & $4,077.7$ & $3,680.0$ & $6,135.5$ & $7,180.9$ & $6,140.5$ \\
Marketing fees & $1,388.8$ & 0.0 & $1,437.4$ & $1,092.1$ & $1,300.3$ \\
Fumigation & 591.1 & 500.0 & 894.0 & $1,474.9$ & $1,013.3$ \\
\hline Losses from spillage & 111.1 & 0.0 & 205.0 & 605.3 & 301.5 \\
\hline Sorting and grading & & & & \\
\hline
\end{tabular}

Source: Author's calculations from SCP survey data (Jun/Jul 2018 and Jan/Feb 2019).

\section{- Maize transfer costs}

In many developing countries, transfer costs are high and variable. High transfer costs largely occur due to poor infrastructure networks and prohibitive trade 'taxes' i.e. local taxes, bribes to police and customs officials, tariffs - all of which stifle trade (Baulch, 1997; Zant, 2018). Table 15 provides a summary of the transfer costs of maize transported between the market pairs tested for integration. Real transfer costs ranged from MWK2 to MWK9 per kg of maize. Looking at the transfer cost to price ratio, the transfer costs accounted for nearly half of the market prices in some instances when prices went as low as MWK20 per kg during main harvest seasons. 
Table 15: Maize transfer costs

\begin{tabular}{|c|c|c|c|c|}
\hline Market pair & $\begin{array}{c}\text { Distance } \\
(\mathbf{k m})\end{array}$ & $\begin{array}{l}\text { Real transfer cost } \\
\text { (MWK/kg) }\end{array}$ & $\begin{array}{l}\text { Real price difference } \\
\text { (MWK/kg) }\end{array}$ & $\begin{array}{c}\text { Transfer cost } \\
\text { (price ratio) }\end{array}$ \\
\hline Lunzu - Mulanje & 64.60 & 1.57 & 2.78 & 0.56 \\
\hline Rumphi - Mzuzu & 65.90 & 1.59 & 6.88 & 0.23 \\
\hline Mzimba - Mzuzu & 116.70 & 2.49 & 0.24 & 10.38 \\
\hline Mchinji - Mitundu & 122.30 & 2.59 & -1.57 & -1.65 \\
\hline Nsanje - Chikwawa & 129.00 & 2.71 & -5.09 & -0.53 \\
\hline Mwanza - Mulanje & 165.80 & 3.36 & -5.27 & -0.64 \\
\hline Mchinji - Chimbiya & 166.00 & 3.36 & 5.00 & 0.67 \\
\hline Chimbiya - Liwonde & 239.90 & 4.66 & -3.02 & -1.54 \\
\hline Mzimba - Mchinji & 287.70 & 5.50 & 0.06 & 91.67 \\
\hline Mzimba - Chimbiya & 296.00 & 5.65 & 5.06 & 1.12 \\
\hline Karonga - Mzimba & 315.20 & 5.99 & 5.57 & 1.08 \\
\hline Chimbiya - Lunzu & 360.30 & 6.78 & -11.70 & -0.58 \\
\hline Mchinji - Lunzu & 398.50 & 7.45 & -6.70 & -1.11 \\
\hline Chimbiya - Mulanje & 440.40 & 8.19 & -8.92 & -0.92 \\
\hline Mchinji - Mulanje & 478.70 & 8.85 & -3.92 & -2.26 \\
\hline
\end{tabular}

Source: Authors' calculations.

\subsubsection{Market efficiency and gross margins}

To analyze traders' efficiency, we used the efficiency ratio, which indicates a trader's expense as a percentage of revenue (expenses/revenue). It represents how much a trader spends to make MWK1 in maize trade. High ratios indicate that traders incur more costs to earn every additional MWK1, while lower ratios would imply that traders are more efficient and typically incur less cost for every additional MWK1 they make. Traders are therefore expected to minimize efficiency ratios, thus reducing expenses and increasing earnings. Table 16 presents findings on trader efficiency and gross margins in the main harvest and lean seasons of 2018/19. Our result shows that traders were inefficient as they incur more costs than revenues in both the lean and harvest seasons.

The level of traders' marketing efficiency also has implications on the overall performance of the maize marketing system. If traders charge prices that are higher than the incurred costs, there are welfare losses as the consumer surplus is reduced. Consumers would lose out due to the high profits made by the traders. On the other hand, reasonable trader margins would be an indication of a good performing market that offers prices that are not harmful to consumers.

Even though the maize traders were generally market inefficient, it is worth mentioning that the use of costs and revenue as a determinant of market performance is a mere indicator of efficiency and should not be over interpreted in a strict sense because of the complexity of maize trade in Malawi. First, maize traders in Malawi had costs and returns that were spread over a long period of time and seasons. In some periods, traders were solely involved in aggregation, and time between purchases and sales varied across traders. Hence, warehousing played a significant role in the maize marketing, especially in intertemporal arbitrage. Second, most traders did not keep records, which makes it hard to trace accrued sales revenue to multiple purchases of maize. Third, the maize market is 
somewhat distorted by state interventions in pricing and oligopolistic tendencies in price setting in regional markets.

In terms of margins, traders made more profits in the lean season when maize was scarce, than in the main harvest season. Margins were reduced in the main harvest seasons for reasons highlighted in the immediate discussion. When asked about general changes in their margins during the three years preceding the survey, about 49 percent of the traders reported minimal changes in margins in that period.

Table 16: Maize trade margins and expenses to revenue ratios

\begin{tabular}{|c|c|c|c|c|c|}
\hline Variable & $\begin{array}{c}\text { Assembler } \\
(\mathrm{n}=45)\end{array}$ & $\begin{array}{l}\text { Broker/agent } \\
(n=10)\end{array}$ & $\begin{array}{l}\text { Retailer } \\
(\mathrm{n}=239)\end{array}$ & $\begin{array}{c}\text { Wholesaler } \\
\quad(n=114)\end{array}$ & $\begin{array}{c}\text { All } \\
(408)\end{array}$ \\
\hline $\begin{array}{l}\text { Gross margin in the main season } \\
\text { ('000'Kwachas) }\end{array}$ & -516.2 & 668.5 & -153.7 & 362.3 & -29.4 \\
\hline $\begin{array}{l}\text { Gross margin in the lean season } \\
\text { ('000'Kwachas) }\end{array}$ & 638.4 & -936.9 & -98.8 & 1500.6 & 408.8 \\
\hline \multicolumn{6}{|l|}{ Changes in margins over 3 years: } \\
\hline Slightly larger & 15.5 & 40.0 & 21.8 & 22.8 & 21.8 \\
\hline Slightly smaller & 40.1 & 30.0 & 27.2 & 28.1 & 49.3 \\
\hline About the same & 44.4 & 30.0 & 51.0 & 49.1 & 28.9 \\
\hline $\begin{array}{l}\text { Marketing efficiency index in the } \\
\text { main season }\end{array}$ & 2.18 & 0.95 & 1.50 & 2.67 & 1.86 \\
\hline $\begin{array}{l}\text { Marketing efficiency index in the } \\
\text { lean season }\end{array}$ & 0.91 & 1.19 & 1.16 & 1.67 & 1.27 \\
\hline
\end{tabular}

Source: Author's calculations from SCP survey data (Jun/Jul 2018 and Jan/Feb 2019).

\subsubsection{Maize price seasonality}

Figure 7 shows a plot of the grand seasonal indices by month for selected markets in northern, central and southern Malawi. On average, the highest GSI occurred in the months of February and March while the lowest GSI occurred in the months of May, June, and July. This is plausible given that February and March are the typical peak of the lean months in the north when maize is scarce, while May, June and July are the main post harvest marketing seasons.

As shown in Figure 7, we observed a high price seasonality in northern region markets. On average, prices in Karonga market were 30 percent higher than the 12-month moving average price in February and 25 percent lower than the average price in May. Prices in Chitipa, Rumphi, and Mzuzu were 27 percent, 19 percent and 30 percent higher than the 12-month moving average prices, respectively during March. On average, the highest GSI occurred in the months of February and March while the lowest GSI occurred in the months of May, June, and July. Of the four northern markets, Karonga Boma had the widest seasonal price gap between the minimum and maximum prices during the study period.

A similar pattern was observed in the central markets, with the highest GSI recorded in February/March while the lowest GSI was recorded in May/July. On average, prices in the central region were 26 percent higher than the average prices in the month of March and 20 percent lower in the month of June. Mitundu recorded the widest seasonal gap of all the central markets where prices were 35 percent higher than the 12-month moving average prices during February and 23 percent lower in June. 
Figure 7: Grand seasonal indices in northern, central and southern region markets
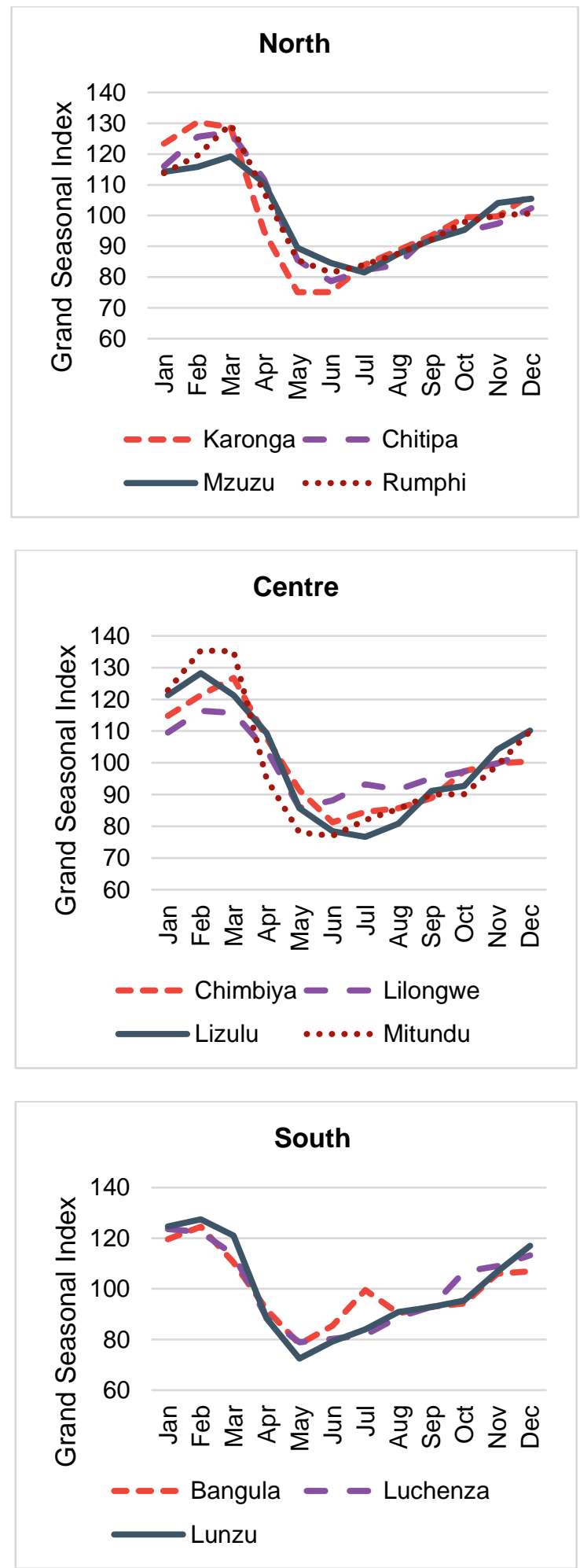

Source: Authors' construction from AMIS data (1989-2019).

In the southern region, the highest GSI was recorded in February and the lowest in May. On average, prices in the southern region were 25 percent higher than the 12-month moving average price during February and 28 percent lower than the average price during June. Lunzu market had the widest seasonal gap of all the three markets. Interestingly, Bangula market in the lower Shire Valley showed a different price trend to other markets, especially between February and August as well as November and December. That said, the Lower Shire where Bangula is located, contributes only 2 percent of the national maize output. The maize price spike in July is plausible as most of the maize 
stocks are depleted by then and marketing of other common staples in the region such as sorghum millet only begins from late July/early August.

We used seasonal gaps to further analyze price seasonality in Table 17 below. The seasonal gap is defined as the difference between the lowest GSI during harvest period and the highest GSI during the peak of the lean season. We can therefore also refer to it as the gross storage margin. Maize price seasonality is substantial in Malawi. The average seasonal gap in the southern region was 48.7 percent, compared to 46.5 and 47.0 percent in the central and northern region respectively. Mitundu, Karonga and Lunzu markets had the highest seasonal price gaps for the last 30 years (1989 to 2018). In contrast, Lilongwe and Mzuzu markets recorded the lowest seasonal gaps.

Column 3 of Table 17 shows the average gross seasonal margin, which represents the percentage increase of the price above the lowest price index level. The average gross seasonal margin was 60.3 percent over the last 30 years, implying that maize prices at the peak of the lean season were usually higher than in the main harvesting season by 60.3 percentage points. These findings are close to the findings by Manda (2010) who found that the lean season prices were higher by 59.8 percent over a 21-year period between 1989 and 2009. Nevertheless, the average gross seasonal margin has narrowed over time especially after the introduction of FISP.

Table 17: Maize price seasonality across Malawi

\begin{tabular}{lcc} 
Market & $\begin{array}{c}\text { Seasonal gap } \\
\text { (difference in index) }\end{array}$ & $\begin{array}{c}\text { Average gross seasonal margin } \\
\text { (\%) }\end{array}$ \\
North & 47.0 & 73.5 \\
Karonga & 55.2 & 59.7 \\
Chitipa & 47.0 & 46.2 \\
Mzuzu & 37.7 & 57.5 \\
Rumphi & 48.2 & \\
Central & 46.5 & 56.0 \\
Chimbiya & 45.5 & 35.7 \\
Lilongwe & 30.6 & 67.3 \\
Lizulu & 51.6 & 75.9 \\
Mitundu & 58.4 & \\
South & 48.7 & 59.3 \\
Bangula & 46.4 & 56.6 \\
Luchenza & 44.7 & 75.9 \\
Lunzu & 55.0 & 60.3 \\
\hline All & 47.3 & \\
\hline
\end{tabular}

Source: Authors' calculations from AMIS data (1989-2018).

Note: Seasonal gap = lowest maize prices during main harvest period - highest price during the peak of the lean season.

\subsubsection{Traders net margins}

As described in Table 17 the average gross seasonal margin, which represents the percentage increase of the price above the lowest price index level, was found to be 60.3 percent over the 30 year period. This margin excluded the cost of storage to properly describe traders benefit from intertemporal maize trade. The principal cost of storage encompasses the rent of storage space and bagging, interest rate on the loan to procure maize, cost of losses in storage and fumigation costs. 
Table 18 presents the average costs of storage per month for traders interviewed. Traders reported incurring much higher costs for bagging and rental of storage space than for handling losses or defumigation.

Table 18: Average trader's physical storage costs over an 8-months period, 2018-19

Cost of storage space (rent)

Cost of chemical treatment (fumigation) 0.98

Total storage cost

24.33

Source: Author's calculations from SCP survey data (Jun/Jul 2018 and Jan/Feb 2019).

Given the average maize price in June 2018 of MWK102/kg, a 60.3 percent gross seasonal margin would equal to MWK61.5/kg. After accounting for the monthly cost of storage shown above, thus yields a net margin as follows:

Net margin $=(61.50)-(24.33)=M W K 37.17 / \mathrm{kg}$

The net margin is therefore 36.4 percent over an 8-month period (June 2018 to February 2019), which equals almost 4 percent per month when compounded. It should be noted that this margin excludes financing costs. Although our survey shows that 83 percent of traders used their own funds to finance their business (Table 11), the own capital that traders tie up in maize stock still has an opportunity cost (what its monetary equivalent could earn in an alternative investment). Over the last five years, the average lending rate has been 40.3 percent per annum (International Financial Statistics, 2019). This gives a compounded interest rate of 2.9 per month with the compounded 8months interest rate at 25.3 percent. Assuming a buying price of MWK102 per kg in June, the cost of financing maize purchases therefore comes to about MWK $25.8 / \mathrm{kg}\left(0.253^{*} 102\right)$ as shown in Figure 8. Subtracting financing and storage costs per $\mathrm{kg}$ from the MWK 61.5/kg price increase gives return to storage of MWK 11.4/kg over an 8-months period (see Appendix B.1. for details of the compounding calculations). When combined with price volatility and the possibility of discretionary trade interventions, these relatively modest returns help to explain why small and medium scale traders are reluctant to store maize for more than three months (Table 5).

\section{Figure 8: Traders' return to intra-seasonal storage}

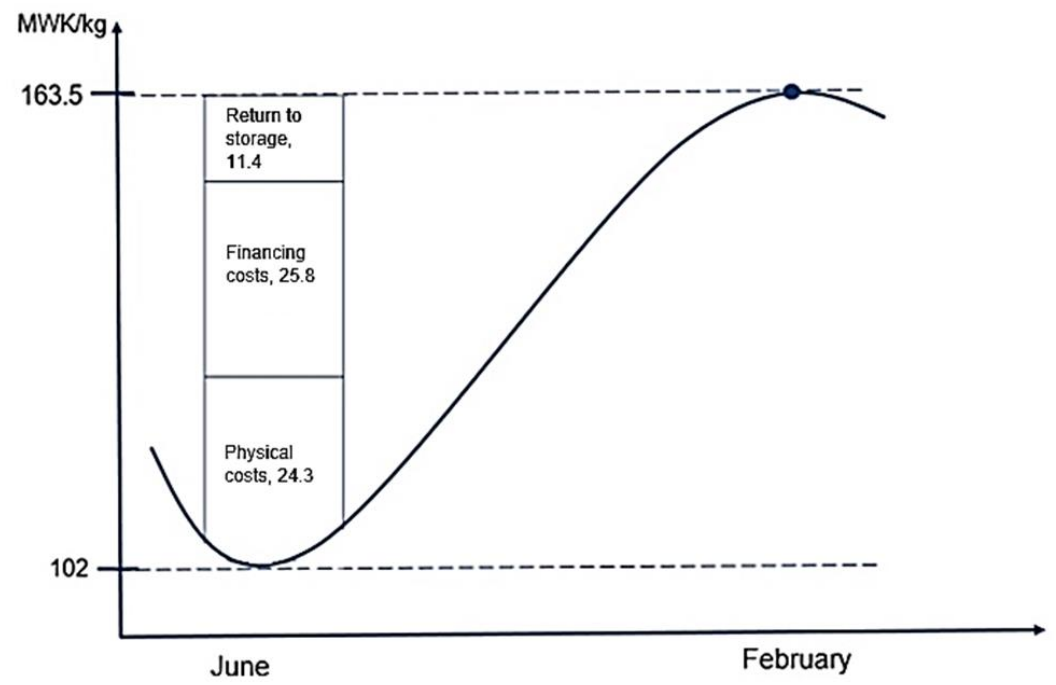

Source: Author's construction/calculations from IFPRI, AMIS and IFS data. Note: MWK, Malawi Kwachas; physical costs refer to storage costs. 


\subsubsection{Spatial integration of maize markets}

This part of the report presents the threshold error correction model results on spatial integration of markets. The model is described in section 3.3.2. We analyzed spatial integration of major maize markets using market pairs that are categorized based on distance into short (less than $150 \mathrm{~km}$ apart), medium (greater than $150 \mathrm{~km}$ but less than $300 \mathrm{~km}$ apart) and long-distance (greater than $150 \mathrm{~km}$ apart) market pairs. This is because in as much as inter and inter-regional market integration would be interesting to analyze, the findings would be flawed in most cases where the inter-regional market pairs were closer to each other than inter-regional market pairs. Table 19 presents the results for integrated market pairs only. Full results for all pairs and regimes can be found in Table A.3, A. 4, and A. 5 in the Appendix. Thirteen of the fifteen market pairs (Figure A.1, A. 2, and A.3 in the Appendix) were integrated in the long-run. Market integration was mostly found when the price difference between the market pairs was higher than the transfer cost. Out of the 35 regime specific tests conducted on long run integration, 12 of them had market integration in the trading regimes. 7 markets out of 35 had trade in the no trade regime. 17 out of 35 had no long run integration. The discussion categorizes market pairs based on distance between them.

\section{Spatial integration in short distance market pairs}

In the short-distance market pairs, four of the five market pairs were integrated under various regimes. The pairs were a mix of southern, central and northern markets and included: Lunzu-Mulanje and Nsanje-Chikwawa in the South; Mchinji-Mitundu in the Center; and, Mzimba-Mzuzu in the North (Table 19). Lunzu-Mulanje market pair was integrated in the no trade and upper regimes and no-trade regimes and prices took about 2 days to converge to long run equilibrium values. The Nsanje-Chikwawa market pair was integrated in the lower regime only, with prices taking about 8 days to adjust to equilibrium values.

The Mchinji-Mitundu market pair was integrated in the lower regime only, taking about 6 days for prices to adjust to long-run equilibrium values. The slow price transmission between this market pair is counterintuitive, given the shorter distance between them and good road network which ordinarily would attract many traders involved in spatial arbitrage and thus facilitate faster price adjustments. However, this slow price adjustment can be explained by the fact that the two markets are in maize surplus areas and limitedly harbor traders involved in spatial arbitrage between the pair.

The Mzimba-Mzuzu pair was integrated in the no trade regime, when price differences between the two markets were lower than the transfer costs, and prices took about 8 days to adjust to their long run equilibrium values. Ordinarily, traders would not be involved in spatial arbitrage if this condition holds. Nevertheless, prices tended to move together in this market pair during this regime. Prices took longer to adjust to long-run equilibrium values in distant market pairs than in proximate pairs. Travel times and transfer costs are usually higher between distant markets and traders may be less aware of the prices in distant markets.

\section{- Spatial integration in medium-distance market pairs}

Five medium-distance market pairs were integrated under various regimes: (1) Mwanza-Mulanje;(2) Mchinji-Chimbiya; (3) Chimbiya-Liwonde; (4) Mzimba-Mchinji; and (5) Mzimba-Chimbiya (Table 19). Mwanza and Mulanje markets were integrated in the upper regime only, taking about 12 days for prices to adjust to long-run equilibrium values. Mchinji and Chimbiya markets were integrated in both the upper and lower regimes. However, price adjustment was instantaneous in the lower regime (when the price in Chimbiya was higher than the price in Mchinji plus transfer cost), as compared to the upper regime, where it took about 19 days to adjust to long-run equilibrium values. Chimbiya-Liwonde market pair was integrated in both no trade and lower regimes, taking about 6 days for prices to adjust to long-run equilibrium values in the no trade regime. Mzimba-Chimbiya pair was integrated in the upper regime, with prices taking 3 months to adjust to long run equilibrium values. 


\section{Spatial integration in long-distance market pairs}

The following four long-distance market pairs were integrated under various regimes: (1): KarongaMzimba; (2) Chimbiya-Lunzu; (3) Mchinji-Lunzu; and (4) Mchinji-Mulanje (Table 19). The Karonga-Mzimba market pair was integrated in the upper and no trade regimes only. Interestingly, price adjustment to equilibrium was faster in the no trade regime (about 7 days) than in the upper regime where it took about 11 days. The two markets are far apart (315 km), a distance longer than between some inter-regional market pairs and characterized by winding, steep road networks through mountainous areas. This contributes to increased transportation costs and limited movement of commodities between the two markets. Furthermore, Karonga is largely a rice producing but a maize deficit area while Mzimba is in a maize surplus area. This explains the slow price transmission and spatial arbitrage between the two markets.

Chimbiya-Lunzu and Mchinji-Lunzu were both integrated in the no trade and lower regimes. For Chimbiya-Lunzu pair, prices adjusted within a day under lower regime. For Mchinji-Lunzu pair, it took 14 days for prices to adjust to long run equilibrium values under no trade regime but days under lower regime. The longest distance was for Mchinji-Mulanje pair that was integrated in no trade regime, with prices taking 46 days to adjust to long run equilibrium values.

\section{Table 19: Tests for market integration}

\begin{tabular}{|c|c|c|c|c|c|c|c|c|}
\hline \multirow[t]{2}{*}{$\begin{array}{l}\text { Distance } \\
\text { category }\end{array}$} & \multirow[t]{2}{*}{ Market pair } & \multirow[t]{2}{*}{$\begin{array}{c}\text { Dis- } \\
\text { tance } \\
(\mathbf{k m})\end{array}$} & \multirow[t]{2}{*}{$\begin{array}{c}\text { No. } \\
\text { of } \\
\text { thresholds }\end{array}$} & \multirow[t]{2}{*}{ Regime } & \multirow[t]{2}{*}{$\begin{array}{c}\text { Regime } \\
\text { frequencies }\end{array}$} & \multicolumn{2}{|c|}{ Speed of adjustment } & \multirow[t]{2}{*}{ LoP } \\
\hline & & & & & & $\alpha$ & Days & \\
\hline \multirow{5}{*}{$\begin{array}{l}\text { Short } \\
(\leq 150)\end{array}$} & \multirow{2}{*}{ Lunzu - Mulanje } & \multirow{2}{*}{64.6} & \multirow{2}{*}{1} & No-trade & 0.19 & $-0.63(0.15)$ & 1.6 & $\mathrm{R}$ \\
\hline & & & & Lower & 0.28 & $-0.51(0.15)$ & 1.9 & $\mathrm{R}$ \\
\hline & Mzimba - Mzuzu & 116.7 & 2 & No-trade & 0.43 & $-0.13(0.11)$ & 7.6 & \\
\hline & Mchinji - Mitundu & 122.3 & 1 & Lower & 0.32 & $-0.17(0.06)$ & 6.03 & $\mathrm{R}$ \\
\hline & Nsanje - Chikwawa & 129 & 2 & Lower & 0.51 & $-0.12(0.06)$ & 8.2 & $\mathrm{R}$ \\
\hline \multirow{7}{*}{$\begin{array}{l}\text { Medium } \\
(\geq 150<300)\end{array}$} & Mwanza - Mulanje & 165.8 & 2 & Upper & 0.06 & $-0.09(0.05)$ & 11.8 & $\mathrm{R}$ \\
\hline & \multirow{2}{*}{ Mchinji - Chimbiya } & \multirow{2}{*}{166.7} & \multirow{2}{*}{2} & Upper & 0.42 & $-0.05(0.03)$ & \multirow{2}{*}{18.9} & $\mathrm{R}$ \\
\hline & & & & Lower & 0.03 & $1.00(-)$ & & A \\
\hline & \multirow{2}{*}{ Chimbiya - Liwonde } & \multirow{2}{*}{239.9} & \multirow{2}{*}{1} & No-trade & 0.69 & $-0.17(0.07)$ & 5.9 & $\mathrm{R}$ \\
\hline & & & & Lower & 0.26 & $1.00(-)$ & 1 & A \\
\hline & Mzimba - Mchinji & 287.7 & 2 & Upper & 0.13 & $-0.06(0.08)$ & 12.3 & $\mathrm{R}$ \\
\hline & Mzimba - Chimbiya & 296.0 & 2 & Upper & 0.48 & $-0.01(0.03)$ & 114.90 & $\mathrm{R}$ \\
\hline \multirow{6}{*}{$\begin{array}{l}\text { Long } \\
(\geq 300)\end{array}$} & \multirow{2}{*}{ Karonga - Mzimba } & \multirow{2}{*}{315.2} & \multirow{2}{*}{1} & Upper & 0.44 & $-0.09(0.09)$ & 10.8 & $\mathrm{R}$ \\
\hline & & & & No-trade & 0.56 & $-0.15(0.08)$ & 6.9 & $\mathrm{R}$ \\
\hline & Chimbiya - Lunzu & 360.3 & 1 & Lower & 0.26 & $1.00(-)$ & 1 & A \\
\hline & \multirow{2}{*}{ Mchinji - Lunzu } & \multirow{2}{*}{398.5} & \multirow{2}{*}{1} & No-trade & 0.76 & $-0.07(0.04)$ & 13.6 & $\mathrm{R}$ \\
\hline & & & & Lower & 0.24 & $-0.19(0.07)$ & 5.4 & $\mathrm{R}$ \\
\hline & Mchinji - Mulanje & 478.7 & 1 & No-trade & 0.69 & $-0.02(0.02)$ & 46.9 & $\mathrm{R}$ \\
\hline
\end{tabular}

Source: Author's calculations from IFPRI daily price data.

Note: Km, kilometers; A, accepted; R, rejected; LoP, Law of one price; Standard errors in (parentheses); Only market pairs integrated in the long-run are presented here but more details can be found in Table A.3 in the appendix. 


\section{- Findings on the Law of One Price}

We tested for the Law of One Price (LoP) for the 15 market pairs and found that the LoP held for three market pairs namely, Mchinji-Chimbiya, Chimbiya-Lunzu and Chimbiya-Liwonde (Table 19). For Mchinji-Chimbiya pair, the LoP held in lower regime only and with few observations whereas the LoP held in lower regimes of the two latter market pairs. For Mchinji-Lunzu, this constituted 82 percent of the total observations, indicating that the LoP held for better part of the study period, while for Chimbiya-Liwonde pair, the LoP held in 26 percent of the observations.

It was apparent that Chimbiya market, in Dedza, one of the maize surplus districts of central Malawi, is a possible center of price formation in the Malawi maize market. Chimbiya market is located along the M1 highway that connects central Malawi with many towns in the South. Chimbiya market is also close to the main border crossing into Tete province in Mozambique.

The fact that the LoP held in the lower regime for Chimbiya market pairs also points to the direction of maize flow across markets. Maize prices are usually higher in the South than in central and northern regions, which facilitates spatial arbitrage between central and southern markets. Therefore, maize flows from Chimbiya to Lunzu and Liwonde markets whenever prices in the latter markets are higher than in Chimbiya, which according to some traders interviewed, led to reduced supplies in Chimbiya. This consequently caused rising prices in an instantaneous process where price adjustments to long-run equilibrium values took a day and the differences in prices between the market pairs were solely accounted for by the transfer costs.

To reduce transaction costs and facilitate spatial arbitrage, traders have over time entrenched informal sales arrangements based on trust and repeated transactions. Most traders involved in spatial arbitrage between Chimbiya and southern and central markets often inquire about prices before ordering maize supplies through phone calls, transfer the cash via bank or mobile money transfer and then have the supplies loaded on trucks. The small hauling companies collect supplies from Chimbiya for various traders and only charge them for the number of transported bags. This enables small traders to engage in spatial arbitrage as the transfer costs are proportionately distributed among the traders. This underscores the role of information technology (through mobile phones) and informal arrangements in spatial market integration of maize markets in Malawi.

\subsubsection{Maize price volatility in selected markets}

Table 20 presents a summary of actual retail maize prices and volatility recorded in selected major markets across the three regions of Malawi over the last two years. Retail maize prices were higher in the southern and northern markets and lower in central region markets. The results are plausible, given that central Malawi accounts for the greatest proportion of national maize output and enough maize supply could keep prices low. Looking at individual markets, Lunzu and Rumphi recorded the highest average price followed by Karonga. Lunzu is located in a traditionally maize deficit area whereas Karonga market is in a largely rice growing area.

Retail maize prices were generally volatile in Malawi in the last two years (Table 20). Maize prices were more volatile in the northern and central region markets than in southern region markets. The highest price volatilities were recorded in Mzimba, Mitundu, Mchinji, and Rumphi markets, which are in traditionally maize surplus areas. Price volatility was lowest in the southern region, particularly in Nsanje and Mwanza markets. The southern region is traditionally maize deficient and therefore maize prices are usually higher in the South than in other regions. Even though maize movement from North to South is limited by high transfer costs, there are significant maize flows into southern region markets from neighboring Mozambique (FEWS NET, 2018). This helps to explain why maize prices are more stable in the South. 
Table 20: Average maize prices and volatility measures in selected markets

\begin{tabular}{|c|c|c|c|c|c|}
\hline Market & Mean & Median & SD & CV & Volatility \\
\hline \multicolumn{6}{|l|}{ North } \\
\hline Karonga & 49.90 & 62.36 & 18.05 & 0.36 & 0.05 \\
\hline Rumphi & 50.97 & 63.87 & 19.56 & 0.38 & 0.05 \\
\hline Mzimba & 44.33 & 53.25 & 18.52 & 0.42 & 0.05 \\
\hline Mzuzu & 44.09 & 52.46 & 16.19 & 0.37 & 0.04 \\
\hline \multicolumn{6}{|l|}{ Centre } \\
\hline Chimbiya & 39.27 & 42.20 & 13.67 & 0.35 & 0.04 \\
\hline Mchinji & 44.27 & 52.63 & 15.15 & 0.34 & 0.05 \\
\hline Mitundu & 45.84 & 54.25 & 15.68 & 0.34 & 0.05 \\
\hline \multicolumn{6}{|l|}{ South } \\
\hline Liwonde & 42.29 & 45.21 & 13.51 & 0.32 & 0.03 \\
\hline Lunzu & 50.97 & 60.28 & 16.03 & 0.31 & 0.04 \\
\hline Mulanje & 48.19 & 51.72 & 14.21 & 0.29 & 0.04 \\
\hline Mwanza & 42.92 & 42.20 & 11.63 & 0.27 & 0.02 \\
\hline Chikwawa & 45.46 & 47.52 & 14.19 & 0.33 & 0.04 \\
\hline Nsanje & 40.37 & 36.30 & 12.66 & 0.31 & 0.02 \\
\hline
\end{tabular}

Source: Authors' calculations for IFPRI data (2017/18.)

Note: $\mathrm{N}=490$; Daily price series from December 1, 2016 to June 30, 2018; Prices are measured in MWK/kg in 2010 prices (with a 6 - day gap in November 2017); SD, Standard deviation; CV, coefficient of variation (SD/mean).

\subsubsection{Maize price volatility in Malawi compared to other countries}

Table 21 shows the maize price volatility based on monthly price data in Malawi as well as other African countries over the past 12 years. Variance ratio tests were used to analyze if there are statistically significant differences in price volatility levels in Malawi vis-à-vis other African countries. Malawi recorded the highest maize price volatility $(0.48)$ compared to other African countries in the region. Maize price volatility was lowest in Ethiopia, a country characterized by very limited price stabilization interventions (Minot, 2014). ${ }^{3}$ Uganda and Tanzania also exhibited higher price volatility relative to other Eastern and Southern African countries. However, there were no statistically significant differences between maize price volatility in Malawi and Uganda or between Malawi and Tanzania.

\footnotetext{
${ }^{3}$ The Ethiopia Grain Trading Enterprise purchases and sells grain on behalf of the government, however its scale of operation is relatively small as compared to the grain market size.
} 
Table 21: Price volatility in selected African countries (March 2006-August 2018)

\begin{tabular}{|c|c|c|c|c|}
\hline Country & $\mathbf{N}$ & Volatility & F-stat & P-value \\
\hline Ethiopia & 138 & 0.27 & 3.13 & $0.00^{* * *}$ \\
\hline Kenya & 138 & 0.31 & 2.45 & $0.00^{* * *}$ \\
\hline Rwanda & 136 & 0.29 & 2.79 & $0.00^{\star \star \star}$ \\
\hline Mozambique & 138 & 0.36 & 1.82 & $0.00^{* \star *}$ \\
\hline South Africa & 138 & 0.39 & 1.50 & $0.02^{* *}$ \\
\hline Uganda & 138 & 0.47 & 1.05 & 0.75 \\
\hline Tanzania & 138 & 0.44 & 1.16 & 0.39 \\
\hline Malawi & 126 & 0.48 & & \\
\hline
\end{tabular}

Source: Authors' calculations based on FAOGIEWS data (2006/18).

Note: ${ }^{*} p<0.10,{ }^{* \star} p<0.05,{ }^{* \star *} p<0.01$.

\subsubsection{Maize price volatility in integrated markets}

It has been argued that spatial market integration reduces food price volatility because integrated markets experience similar price co-movements that will equate their prices in the long run (Jacks et al., 2011). We therefore tested for significant differences in price volatility between spatially integrated markets using variance ratio tests. Table 22 shows the results.

There were significant differences in volatility in nearly all market pairs, except for Mchinji-Mitundu, Mzimba-Mchinji, Chimbiya-Mulanje, and Chimbiya-Lunzu. This is consistent with existence of the LoP in those market pairs that exhibited similar price volatility. In contrast, markets that had regimespecific spatial market integration and slow price transmission had significant differences in their levels of price volatility. This is plausible, given that regime specific market integration suggests asynchronous price movement even between markets. 
Table 22: Variance ratio tests for spatially integrated markets in Malawi

\begin{tabular}{|c|c|c|c|c|}
\hline Market pair & Combined volatility & Difference & F-stat & P-value \\
\hline Karonga - Mzimba & 0.05 & 0.01 & 0.79 & $0.02^{\star \star}$ \\
\hline Mzimba - Mzuzu & 0.05 & 0.01 & 1.50 & $0.00^{\star \star \star}$ \\
\hline Mchinji - Chimbiya & 0.05 & 0.01 & 1.52 & $0.00^{\star * *}$ \\
\hline Mchinji - Mitundu & 0.05 & 0.00 & 1.00 & 0.99 \\
\hline Lunzu - Mulanje & 0.04 & 0.00 & 0.83 & $0.06^{*}$ \\
\hline Mwanza - Mulanje & 0.04 & 0.02 & 0.32 & $0.00^{\star \star \star}$ \\
\hline Nsanje - Chikwawa & 0.00 & 0.01 & 0.41 & $0.00^{\star \star \star}$ \\
\hline Mzimba - Mchinji & 0.05 & 0.00 & 1.06 & 0.54 \\
\hline Mzimba - Chimbiya & 0.05 & 0.01 & 1.61 & $0.00^{\star * *}$ \\
\hline Mchinji - Mulanje & 0.05 & 0.01 & 1.30 & $0.01^{* *}$ \\
\hline Mchinji - Lunzu & 0.04 & 0.01 & 1.56 & $0.00^{\star \star *}$ \\
\hline Chimbiya - Mulanje & 0.04 & 0.00 & 0.86 & 0.11 \\
\hline Chimbiya - Lunzu & 0.04 & 0.00 & 1.03 & 0.79 \\
\hline Chimbiya - Liwonde & 0.04 & 0.01 & 1.81 & $0.0000^{* * *}$ \\
\hline
\end{tabular}

Source: Authors' calculations based on IFPRI data (2016/18).

Note: ${ }^{*} p<0.10,{ }^{* *} p<0.05,{ }^{* * *} p<0.01$.

\section{CONCLUSIONS AND POLICY IMPLICATIONS}

Seasonal analysis of the SCP of markets for staple crops has received relatively little attention in food policy analysis but has important implications for food security. We employed a mixed methods approach to analyze the structure, conduct and performance of maize markets in Malawi during the 2018/19 main and lean harvest seasons. We interviewed 749 traders from 74 markets across eight districts from Mulanje in the South to Chitipa in the North and held 28 FGDs with a total of 480 farmers. Daily and weekly retail maize price data from 13 regional markets monitored by IFPRI, World Food Programme (WFP) and Ministry of Agricultural, Irrigation and Water Development (MoAIWD) were also analyzed to assess the spatial and temporal performance of maize markets.

We find that Malawi's maize market is characterized by: (1) considerable inequality in sales revenue among traders of similar capacities; (2) widespread lack of structured trading despite existing institutions; (3) a high ratio of marketing costs to revenue suggesting marketing inefficiencies; (4) high price seasonality (with lean season prices 60 percentage points higher than main harvest season prices); and (5) high price volatility compared to neighboring countries. Further, in contrast to other studies, we find that the country's maize markets are poorly spatially integrated even among shortdistance market pairs.

Malawi's maize market is pyramidal in structure: highly competitive at lower tiers of trade (where there are many small traders) but 'oligopolistic' at higher tiers (where there are just a handful of large private traders at the national level). Both farmers and small traders perceived this as a disincentive to engaging in the maize trade. They felt that large private traders depress prices during the main marketing season and inflate them during the lean season. Our study also found heterogeneous pricing mechanisms among traders. While most traders employed cost-plus pricing, some colluded to set prices or followed market leaders. Only a few cases of predatory pricing by influential traders or quality-based pricing were reported. 
The unpredictable regulatory environment is a disincentive to more spatial and temporal arbitrage by maize traders. ADMARC, the state agricultural commodity marketing corporation, is an influential player in Malawi's maize markets. However, small farmers and traders viewed the corporation as favoring large private traders, due to the delayed and unpredictable nature of its procurement and sales operations. ADMARC tends to buy maize at the tail end of the main marketing season, when most maize has already been sold to large private traders with warehousing capacities, who then sell on to ADMARC. The corporation often does not have enough funds to purchase surplus stocks from farmers, therefore dampening competition and depressing prices for farmers and small traders. There is need for more private sector investment in maize marketing, more affordable warehousing, and more competition among buyers, especially in remote areas.

Focus group discussions with farmers revealed that nearly all farmers produced largely for their own consumption, with any surpluses occasionally sold to settle pressing household financial needs. The fact that maize production is not considered as a business by most farmers has substantial implications for economic access to and physical availability of the staple throughout the year.

We observed instances of trade reversals, where maize flowed from rural to urban areas during the main harvest season and vice versa during the lean season. Again, greater investment in warehousing, especially in remote areas, would increase maize availability during the lean season and help to stabilize maize prices. The cyclical nature of the maize trade also leads to variations in marketing channels across seasons. Switches between trader types were observed between seasons, i.e. from wholesaler to retailer, and village assembler to retailer.

Inadequate access to credit was found to be a critical barrier to the expansion of maize trade. This problem is compounded by a largely informal maize marketing system, in which most small traders are not legally registered. Farmers and small and medium scale traders struggle to obtain credit due to stringent collateral requirements and high interest rates. The Malawi government should work with the financial sector to reach out more to them. Better access to credit will help acquire productive assets, such as quality improving equipment and warehouses.

Given the limited awareness of the existing structured trading opportunities such as commodity exchanges and WRS, it is imperative that awareness of commodity exchanges be raised to enable farmers and small traders to access the benefits of accessing pricing information and market opportunities from commodity exchanges.

Transport costs are high in land-locked Malawi with high fuel prices and poor rural road networks. Road infrastructure needs to be improved to reduce transfer costs which, along with improving access to market information, will promote spatial arbitrage.

Finally, Malawi's maize value chain is characterized by a widespread lack of standardized grading and quantity measures. Furthermore, grading and quality standards are not harmonized, and quality premiums are rarely paid. We found regional variations in the use and accuracy of weighing scales among traders (including ADMARC). Weighing scales were widely used in the central and southern region markets, but not in the North where buyers mainly use pails. We also found little investment in quality improving equipment and practices that could help to avoid significant post-harvest losses, especially those from aflatoxin and insect infestation. Poorly harmonized standards and a lack of quality control prevent the development of structured markets (such as commodity exchanges, warehouse receipt systems, and marketing contracts) that might help to stabilize maize volumes and prices. Institutionalizing and enforcing quality grades and measurement standards will promote structured trading and reduce cheating by a minority of unscrupulous traders. 


\section{ABOUT THE AUTHORS}

Dennis O. Ochieng is Associate Research Fellow at IFPRI Malawi and leads the Strengthening Agricultural Markets and Institutions theme within the Malawi Strategy Support Program (MaSSP).

Rosemary Botha is Research Analyst within the Strengthening Agricultural Markets and Institutions Theme of the program.

Bob Baulch is a Senior Research Fellow and IFPRI Malawi's Program Leader.

\section{ACKNOWLEDGEMENTS}

This research was made possible with funding from the United States Agency for International Development (USAID) and the UK Department for International Development (DFID). We also acknowledge WFP for providing maize price data and the editorial work of Sandra FröbeKaltenbach. We express gratitude to all the farmers and traders interviewed during the study and appreciate their efforts in maize marketing. 


\section{REFERENCES}

Baulch, B. 1997. "Transfer Costs, Spatial Arbitrage, and Testing for Food Market Integration." American Journal of Agricultural Economics: 79 (2), 477-487.

Baulch, B., A. Gondwe, and C. Chafuwa. 2018b. Impacts of the 2016/17 Food Insecurity Response Program on Maize Prices in Malawi. MaSSP Working Paper 22. Lilongwe, Malawi: International Food Policy Research Institute.

Baulch, B., A. Gross, J. D. Chimgonda-Nkhoma, and M. Chikumbutso. 2018a. Commodity Exchanges and Warehouse Receipts in Malawi. MaSSP Working Paper 25. Lilongwe, Malawi: International Food Policy Research Institute.

Baulch, B., H. Hansen, L. D. Trung, and T. N. Tam. 2008. "The Spatial Integration of Paddy Markets in Vietnam." Journal of Agricultural Economics: 59 (2), 271-295.

CTA and EAGC. 2013. Structured Grain Trading Systems in Africa. Wageningen, Nairobi: Technical Center for Agricultural and Rural Cooperation, East Africa Grain Council, Nairobi.

Dabalen, A., A. de la Fuente, A. Goyal, W. Karamba, N.T.V. Nguyen, and T. Tomomi. 2017. Pathways to Prosperity in Rural Malawi. Washington DC: World Bank.

Derlagen C. 2012. Analysis of Incentives and Disincentives for Maize in Malawi. Technical Notes Series. Rome: MAFAP, FAO.

Dillon, B. 2017. "Selling Crops Early to Pay for School: A Large-scale Natural Experiment in Malawi." http://dx.doi.org/10.2139/ssrn.2848003.

Edelman, B., and B. Baulch. 2016. Are Malawi's maize and soya trade restrictions causing more harm than good? A summary of evidence and practical alternatives. MaSSP Policy Note 25. Lilongwe, Malawi: International Food Policy Research Institute.

Edelman, B., A. Mabiso, Z. Nyirenda, and C. Kazembe. 2016. Have Maize Market Policies Turned Malawi's Large-scale Farmers into Subsistence Producers. MaSSP Policy Note 24. Lilongwe, Malawi: International Food Policy Research Institute.

FAO (Food and Agriculture Organization of the United Nations). 2019. FAOSTAT database. Accessed May 2019. http://faostat.fao.org.

FEWS NET (Famine Early Warning Systems Network). September 2018. "Malawi Food Security Outlook Update."

Gilbert, C.L., L. Christiaensen, and J. Kaminski. 2017. "Food Price Seasonality in Africa: Measurement and Extent." Food Policy 67: 119132.

Goetz, S.J., and M. T. Weber. 1986. Fundalmentals of Price Analysis in Developing Countries Food Systems: A Training Manual to Accompany the Microcomputer Software Program "MSTAT". International Development Working Paper 29. Washington: Michigan State University.

IFS (International Financial Statistics). 2019. Prices, Consumer Price Indices [Data File]. Washington, DC: International Monetary Fund. Accessed May 20, 2019. .

Jacks, D. S., K. H. O'Rourke, and J. G. Williamson. 2011. "Commodity Price Volatility and World Market Integration since 1700." The Review of Economics and Statistics 93 (3): 800-813.

Jayne, T. S., N. Sitko, J. Ricker-Gilbert, and J. Mangisoni. 2010. "Malawi's Maize Marketing System." Lilongwe: Report commissioned by the World Bank and Ministry of Agriculture of the Government of Malawi, Lilongwe.

Lo, M. C., and E. Zivot. 2001. "Threshold Cointegration and Nonlinear Adjustment to the Law of one Price." Macroeconomic Dynamics, 5 (4): 533-576.

Lunduka, R., M. Fisher, and S. S. Snapp. 2012. "Could Farmer Interest in a Diversity of Seed Attributes Explain Adoption Plateaus for Modern Maize Varieties in Malawi." Food Policy 37 (5): 504-510.

Manda, E. L. 2010. Price Instability in the Maize market in Malawi. Norwich, UK: University of East Anglia, School of International Development Studies.

Mezui, C.A.M., L. Rutten, S. Sekioua, J. Zhang, M. M N'Diaye, N. Kabanyane, Y. Arvanitis, U. Duru, and B. Nekati. 2013. Guidebook on African Commodity and Derivatives Exchanges. Tunis: African Development Bank.

Minot, N. 2014. "Food Price Volatility in Sub-Saharan Africa: Has it Really Increased?" Food Policy 45: 45-56.

MoAIWD (Malawi Ministry of Agriculture, Irrigation and Water Development). 2019. Agricultural Production Estimate Survey. Lilongwe: MoAIWD.

Mussa, R. 2015. "Do the Poor Pay More for Maize in Malawi?" Journal of International Development 27 (4): 546-563. 
Myers, R. J. 2013. "Evaluating the effectiveness of Inter-Regional Trade and Storage in Malawi's Private Sector Maize Markets." Food Policy 41: 75-84.

NSO (National Statistical Office). 2018. Malawi Population and Housing Census Preliminary Report. Zomba, Malawi.

Ochieng, D. O., R. Botha, and B. Baulch. 2018. Structure, Conduct, Performance of Maize Markets in Malawi. MaSSP Report. Lilongwe, Malawi: International Food Policy Research Institute.

Parker, R. C., and J. M. Connor. 1979. "Estimates for Consumer Loss due to Monopoly in the U.S Food Manufacturing Industries." American Journal of Agricultural Economics: 626-639.

Porteous, O. 2017. "Empirical Effects of Short-term Export Bans: The Case of African Maize." Food Policy 71: 17-26.

Ragasa, C. 2019. Modeling the Effectiveness of the Lead Farmer Approach in Agricultural Extension Service Provision: Nationally Representative Panel Data Analysis in Malawi. IFPRI Discussion Paper 1848. Washington, DC: International Food Policy Research Institute.

Sitko, N. J., and T. S. Jayne. 2014. "Exploitative Briefcase Businessmen, Parasites, and other Myths and Legends: Assembly Traders and the Performance of Maize Markets in Eastern and Southern Africa." World Development 54: 56-67.

Sitko, N. J., J. Chamberlain, B. Cunguara, M. Muvanga, and J. Mangisoni. 2017. "A Comparative Political Economic Analysis of Maize Sector Policies in Eastern and Southern Africa." Food Policy 69: 243-255.

Stock, J. H., and M. W. Watson. 2011. Introduction to Econometrics. Boston: Pearson.

Stokstad, E., 2017. "New Crop Pest Takes Africa at Lightning Speed." Science 356 (6337): 473-474.

Timmer, C. P., W. D. Falcon, and S. R. Pearson. 1983. Food Policy Analysis. Baltimore MD: Johns Hopkins University Press.

World Bank. 2017. "Living Standards Measurement Study: Integrated Surveys on Agriculture." Accessed on 12. November 2018 http://web.worldbank.org/WBSITE/EXTERNAL/EXTDEC/EXTRESEARCH/EXTLSMS/EXTSURAGRI/0,,contentMDK:22800726 men UPK:7420278pagePK:64168445piPK:64168309theSitePK:7420261,00.html

Zant, W. 2018. "Trains, Trade, and Transaction Costs: How Does Domestic Trade by Rail Affect Market Prices of Malawi Agricultural Commodities?" The World Bank Economic Review 32 (2): 334-356. 


\section{APPENDICES}

Table A. 1: Sampled markets

\begin{tabular}{|c|c|c|c|c|c|}
\hline NO. & MARKET & DISTRICT & No. & MARKET & DISTRICT \\
\hline 1 & Area 23 & Lilongwe City & 38 & Lupembe & Karonga \\
\hline 2 & Area49 & Lilongwe City & 39 & Madede & Mzimba \\
\hline 3 & Bangwe & Blantyre City & 40 & Madisi & Dowa \\
\hline 4 & Chankhungu & Dowa & 41 & Madziabango & Blantyre \\
\hline 5 & Cheyadi & Mchinji & 42 & Madzimayera & Mchinji \\
\hline 6 & Chigwirizano & Lilongwe City & 43 & Malomo & Ntchisi \\
\hline 7 & Chikuse & Mulanje & 44 & Mathambi & Mulanje \\
\hline 8 & Chikwatula & Ntchisi & 45 & Mbayani & Blantyre City \\
\hline 9 & Chilipa & Blantyre & 46 & Mchesi & Lilongwe City \\
\hline 10 & Chimbalanga & Mulanje & 47 & Mchinjiboma & Mchinji \\
\hline 11 & Chimwaza & Dowa & 48 & Mgona & Lilongwe City \\
\hline 12 & Chinakanaka & Mulanje & 49 & Mitundu & Lilongwe \\
\hline 13 & Chinkhoma & Kasungu & 50 & Mkando & Mulanje \\
\hline 14 & Chinsapo & Lilongwe City & 51 & Mlare & Karonga \\
\hline 15 & Chiosya & Mchinji & 52 & Mpingu & Mchinji \\
\hline 16 & Chirimba & Blantyre City & 53 & Mponela & Dowa \\
\hline 17 & Chitipaboma & Chitipa & 54 & Mtandire & Lilongwe City \\
\hline 18 & Chiuzira & Lilongwe & 55 & Mtunthama & Kasungu \\
\hline 19 & Edingeni & Mzimba & 56 & Mwanakhu & Mulanje \\
\hline 20 & Ekwendeni & Mzimba & 57 & Mzimba Boma & Mzimba \\
\hline 21 & Jenda & Mzimba & 58 & Namitete & Lilongwe \\
\hline 22 & Kachere & Blantyre City & 59 & Namitondo & Lilongwe \\
\hline 23 & Kamphata & Lilongwe & 60 & Namphungo & Mulanje \\
\hline 24 & Kamwendo & Mchinji & 61 & Nanjiri & Lilongwe \\
\hline 25 & Kaonekera & Chitipa & 62 & Nathenje & Lilongwe \\
\hline 26 & Kaphiri & Lilongwe City & 63 & Ngwenya & Lilongwe City \\
\hline 27 & Kapiri & Mchinji & 64 & Nkhamenya & Kasungu \\
\hline 28 & Kaporo & Karonga & 65 & Nsundwe & Lilongwe \\
\hline 29 & Karonga Boma & Karonga & 66 & Nsungwi & Lilongwe City \\
\hline 30 & Kasungu Boma & Kasungu & 67 & Ntchisi Boma & Ntchisi \\
\hline 31 & Kawale & Lilongwe City & 68 & Pusi & Karonga \\
\hline 32 & Kunthembwe & Blantyre & 69 & Ruo & Mulanje \\
\hline 33 & Limbuli & Mulanje & 70 & Soche Kwale & Mulanje \\
\hline 34 & Lirangwe & Blantyre & 71 & Tondola & Chitipa \\
\hline 35 & Ludzi & Mchinji & 72 & Wakawaka & Lilongwe City \\
\hline 36 & Lufita & Chitipa & 73 & Zigwagwa & Mzuzu City \\
\hline 37 & Lunzu & Blantyre & 74 & Zingwangwa & Blantyre City \\
\hline
\end{tabular}


Table A. 2: Test of differences in proportion of purchases and sales across seasons (Mann-Whitney tests)

\begin{tabular}{|c|c|c|c|c|c|c|c|c|c|c|}
\hline \multirow{2}{*}{ Sellers / buyers } & \multicolumn{2}{|c|}{ Assembler } & \multicolumn{2}{|c|}{ Broker/Agent } & \multicolumn{2}{|c|}{ Retailer } & \multicolumn{2}{|c|}{ Wholesaler } & \multicolumn{2}{|r|}{ All } \\
\hline & Prob. & P-value & Prob. & P-value & Prob. & P-value & Prob. & P-value & Prob. & P-value \\
\hline \multicolumn{11}{|l|}{ Purchases } \\
\hline Small-scale farmers & 0.7 & $0.0002^{* * *}$ & 0.6 & 0.3 & 0.6 & $0.0000^{* * *}$ & 0.6 & $0.0013^{\star * *}$ & 0.6 & $0.0000^{* * *}$ \\
\hline Farmers Associations & - & - & - & - & 0.5 & 0.2 & 0.5 & 0.1 & 0.5 & $0.0430^{\star *}$ \\
\hline Other traders & 0.3 & $0.0001^{* \star *}$ & 0.6 & 0.5 & 0.4 & $0.0000^{* * *}$ & 0.4 & $0.0008^{* * *}$ & 0.4 & $0.0000^{* * *}$ \\
\hline \multicolumn{11}{|l|}{ Sales } \\
\hline Households/individuals & 0.5 & 0.5 & 0.3 & 0.2 & 0.6 & $0.0000^{\star * *}$ & 0.4 & $0.0009^{* * *}$ & 0.5 & 0.2 \\
\hline Retail stores & 0.5 & $0.0799^{*}$ & - & - & 0.5 & $0.0084^{\star * *}$ & 0.5 & $0.0340^{\star * *}$ & 0.5 & $0.0002^{* \star *}$ \\
\hline Processors & 0.4 & $0.0017^{\star * *}$ & 0.4 & 0.1 & 0.5 & $0.0039^{* \star *}$ & 0.5 & 0.7 & 0.5 & $0.0004^{* \star *}$ \\
\hline Other traders & 0.5 & 0.8 & 0.4 & 0.6 & 0.5 & 0.7 & 0.5 & 0.9 & 0.5 & 0.4 \\
\hline
\end{tabular}

Source: Author's calculations from SCP survey data (Jun/Jul 2018 and Jan/Feb 2019).

Note: ${ }^{*}{ }^{* *},{ }^{* * *}$, differences are significant at the $10 \%, 5 \%$ and $1 \%$ level, respectively. 
Table A. 3: Tests for market integration

\begin{tabular}{|c|c|c|c|c|c|c|c|c|c|}
\hline \multirow[t]{2}{*}{$\begin{array}{l}\text { Distance } \\
\text { category }\end{array}$} & \multirow[t]{2}{*}{ Market pair } & \multirow[t]{2}{*}{ Distance (km) } & \multirow[t]{2}{*}{ No. of thresholds } & \multirow[t]{2}{*}{ Regime } & \multirow[t]{2}{*}{ Regime frequencies } & \multirow[t]{2}{*}{$\begin{array}{l}\text { Long-run integra- } \\
\text { tion }\end{array}$} & \multicolumn{2}{|c|}{ Speed of adjustment } & \multirow[t]{2}{*}{ LoP } \\
\hline & & & & & & & $\alpha$ & Days & \\
\hline & & & & Upper & 0.53 & $\mathrm{R}$ & & & \\
\hline & Lunzu - Mulanje & 64.60 & 1 & No-trade & 0.19 & $A$ & $-0.63(0.15)$ & 1.60 & $\mathrm{R}$ \\
\hline & & & & Lower & 0.28 & $A$ & $-0.51(0.15)$ & 1.90 & $\mathrm{R}$ \\
\hline & & & & Upper & 0.87 & $\mathrm{R}$ & & & \\
\hline & Rumphi - Mzuzu & 65.90 & 1 & No-trade & 0.09 & $\mathrm{R}$ & & & \\
\hline & & & & Lower & 0.04 & $\mathrm{R}$ & & & \\
\hline & & & & Upper & 0.26 & $\mathrm{R}$ & & & \\
\hline \multirow[t]{8}{*}{ Short $(\leq 150)$} & Mzimba - Mzuzu & 116.70 & 2 & No-trade & 0.43 & $A$ & $-0.13(0.11)$ & 7.60 & \\
\hline & & & & Lower & 0.31 & $\mathrm{R}$ & & & $\mathrm{R}$ \\
\hline & & & & Upper & 0.02 & $\mathrm{R}$ & & & \\
\hline & Mchinji - Mitundu & 122.30 & 1 & No-trade & 0.66 & $\mathrm{R}$ & & & \\
\hline & & & & Lower & 0.32 & $A$ & $-0.17(0.06)$ & 6.03 & $\mathrm{R}$ \\
\hline & & & & Upper & 0.14 & $\mathrm{R}$ & & & \\
\hline & Nsanje - Chikwawa & 129.00 & 2 & No-trade & 0.35 & $\mathrm{R}$ & & & \\
\hline & & & & Lower & 0.51 & $A$ & $-0.12(0.06)$ & 8.20 & $\mathrm{R}$ \\
\hline
\end{tabular}


Table A.3 continued

\begin{tabular}{|c|c|c|c|c|c|c|c|c|c|}
\hline \multirow[t]{2}{*}{$\begin{array}{l}\text { Distance } \\
\text { category }\end{array}$} & \multirow[t]{2}{*}{ Market pair } & \multirow[t]{2}{*}{ Distance (km) } & \multirow[t]{2}{*}{ No. of thresholds } & \multirow[t]{2}{*}{ Regime } & \multirow[t]{2}{*}{ Regime frequencies } & \multirow[t]{2}{*}{ Long-run integration } & \multicolumn{2}{|c|}{ Speed of adjustment } & \multirow[t]{2}{*}{ LoP } \\
\hline & & & & & & & $\alpha$ & Days & \\
\hline & & & & Upper & 0.06 & $A$ & $-0.09(0.05)$ & 11.80 & $\mathrm{R}$ \\
\hline & Mwanza - Mulanje & 165.80 & 2 & No-trade & 0.27 & $\mathrm{R}$ & & & \\
\hline & & & & Lower & 0.67 & $\mathrm{R}$ & & & \\
\hline & & & & Upper & 0.42 & $A$ & $-0.05(0.03)$ & 18.90 & $\mathrm{R}$ \\
\hline & Mchinji - Chimbiya & 166.70 & 2 & No-trade & 0.55 & $\mathrm{R}$ & & & \\
\hline & & & & Lower & 0.03 & $A$ & $1.00(-)$ & & $A$ \\
\hline & & & & Upper & 0.05 & $\mathrm{R}$ & & & \\
\hline \multirow[t]{8}{*}{ Medium $(\geq 150<300)$} & Chimbiya - Liwonde & 239.90 & 1 & No-trade & 0.69 & A & $-0.17(0.07)$ & 5.90 & $\mathrm{R}$ \\
\hline & & & & Lower & 0.26 & A & $1.00(-)$ & 1.00 & $A$ \\
\hline & & & & Upper & 0.13 & $A$ & $-0.06(0.08)$ & 12.30 & $\mathrm{R}$ \\
\hline & Mzimba - Mchinji & 287.70 & 2 & No-trade & 0.79 & $\mathrm{R}$ & & & \\
\hline & & & & Lower & 0.08 & $\mathrm{R}$ & & & \\
\hline & & & & Upper & 0.48 & $A$ & $-0.01(0.03)$ & 114.90 & $\mathrm{R}$ \\
\hline & Mzimba - Chimbiya & 296.00 & 2 & No-trade & 0.47 & $\mathrm{R}$ & & & \\
\hline & & & & Lower & 0.06 & $\mathrm{R}$ & & & \\
\hline
\end{tabular}


Table A.3 continued

\begin{tabular}{|c|c|c|c|c|c|c|c|c|c|}
\hline \multirow[t]{2}{*}{$\begin{array}{l}\text { Distance } \\
\text { category }\end{array}$} & \multirow[t]{2}{*}{ Market pair } & \multirow[t]{2}{*}{ Distance (km) } & \multirow[t]{2}{*}{ No. of thresholds } & \multirow[t]{2}{*}{ Regime } & \multirow[t]{2}{*}{ Regime frequencies } & \multirow[t]{2}{*}{ Long-run integration } & \multicolumn{2}{|c|}{ Speed of adjustment } & \multirow[t]{2}{*}{ LoP } \\
\hline & & & & & & & $\alpha$ & Days & \\
\hline & & & 1 & Upper & 0.44 & $A$ & $-0.09(0.09)$ & 10.80 & $\mathrm{R}$ \\
\hline & Karonga - Mzimba & 315.2 & & No-trade & 0.56 & $A$ & $-0.15(0.08)$ & 6.90 & $\mathrm{R}$ \\
\hline & & & & Lower & $\mathrm{T}$ & & & & \\
\hline & & & 1 & Upper & 0.05 & $\mathrm{R}$ & & & \\
\hline & Chimbiya - Lunzu & 360.30 & & No-trade & 0.69 & $\mathrm{R}$ & & & $\mathrm{R}$ \\
\hline & & & & Lower & 0.26 & A & $1.00(-)$ & 1.00 & A \\
\hline & & & 1 & Upper & $\mathrm{T}$ & & & & \\
\hline \multirow[t]{8}{*}{ Long $(\geq 300)$} & Mchinji - Lunzu & 398.50 & & No-trade & 0.76 & A & $-0.07(0.04)$ & 13.6 & $\mathrm{R}$ \\
\hline & & & & Lower & 0.24 & A & $-0.19(0.07)$ & 5.40 & $\mathrm{R}$ \\
\hline & & & 0 & Upper & $\mathrm{T}$ & $\mathrm{R}$ & & & \\
\hline & Chimbiya - Mulanje & 440.40 & & No-trade & 0.4 & & & & \\
\hline & & & & Lower & 0.6 & & & & \\
\hline & & & 1 & Upper & $\mathrm{T}$ & & & & \\
\hline & Mchinji - Mulanje & 478.70 & & No-trade & 0.69 & $A$ & $-0.02(0.02)$ & 46.9 & $\mathrm{R}$ \\
\hline & & & & Lower & 0.31 & $\mathrm{R}$ & & & \\
\hline
\end{tabular}

Source: Author's calculations from IFPRI daily price data.

Note: Km, kilometers; A, accepted; R, rejected; LoP, Law of one price; Standard errors in (parentheses); T, only one threshold; NT, no threshold effects. 
Table A. 4: Unit root tests (DF-GLS) of stationarity of markets

\begin{tabular}{|c|c|c|c|c|}
\hline \multirow[b]{2}{*}{ Market } & \multicolumn{2}{|c|}{ Levels } & \multicolumn{2}{|c|}{ First differences } \\
\hline & Intercept only & Trend and intercept & Intercept only & Trend and intercep \\
\hline \multicolumn{5}{|l|}{ North } \\
\hline Karonga & -0.21 & -1.52 & -1.38 & -2.91 \\
\hline Rumphi & -0.77 & -1.89 & -22.21 & -22.18 \\
\hline Mzimba & 0.54 & -1.83 & -12.78 & -12.84 \\
\hline Mzuzu & -1.06 & -1.94 & -21.15 & -21.13 \\
\hline \multicolumn{5}{|l|}{ Centre } \\
\hline Chimbiya & 0.44 & -1.88 & -21.67 & -22.34 \\
\hline Mchinji & -0.15 & -1.86 & -21.92 & -22.49 \\
\hline Mitundu & -0.11 & -2.13 & -6.28 & -20.94 \\
\hline \multicolumn{5}{|l|}{ South } \\
\hline Lunzu & 0.13 & -2.08 & -22.78 & -22.82 \\
\hline Mulanje & 0.66 & -3.60 & -18.54 & -24.93 \\
\hline Liwonde & -1.87 & -2.23 & -8.94 & -9.01 \\
\hline Mwanza & -2.45 & -2.89 & -19.14 & -19.32 \\
\hline Chikwawa & -1.41 & -3.04 & -22.92 & -22.90 \\
\hline Nsanje & -1.39 & -1.80 & -24.04 & -24.02 \\
\hline
\end{tabular}

Source: Authors' calculations.

Note: The $1 \%, 5 \%$ and $10 \%$ critical values for intercept only are $-2.56,-1.94$ and -1.62 respectively. The $1 \%, 5 \%$ and $10 \%$ critical values for intercept and trend are $-3.48,-2.89$ and -2.57 respectively. 
Table A. 5: Bounds test of cointegration of price series

\begin{tabular}{lccc}
\hline Market pair & F-stat & I(0) bound & I(1) bound \\
\hline Karonga - Mzimba & & 3.62 & 4.16 \\
Chimbiya - Liwonde & 2.32 & 3.62 & 4.16 \\
Lunzu - Mulanje & 0.67 & 3.62 & 4.16
\end{tabular}

Source: Authors' calculations.

Note: Test done only in cases of market pairs integrated in all regimes; $I(0)$ and $I(1)$ critical values at $5 \%$ significance level. 
Figure A. 1: Map of spatially integrated markets in Malawi

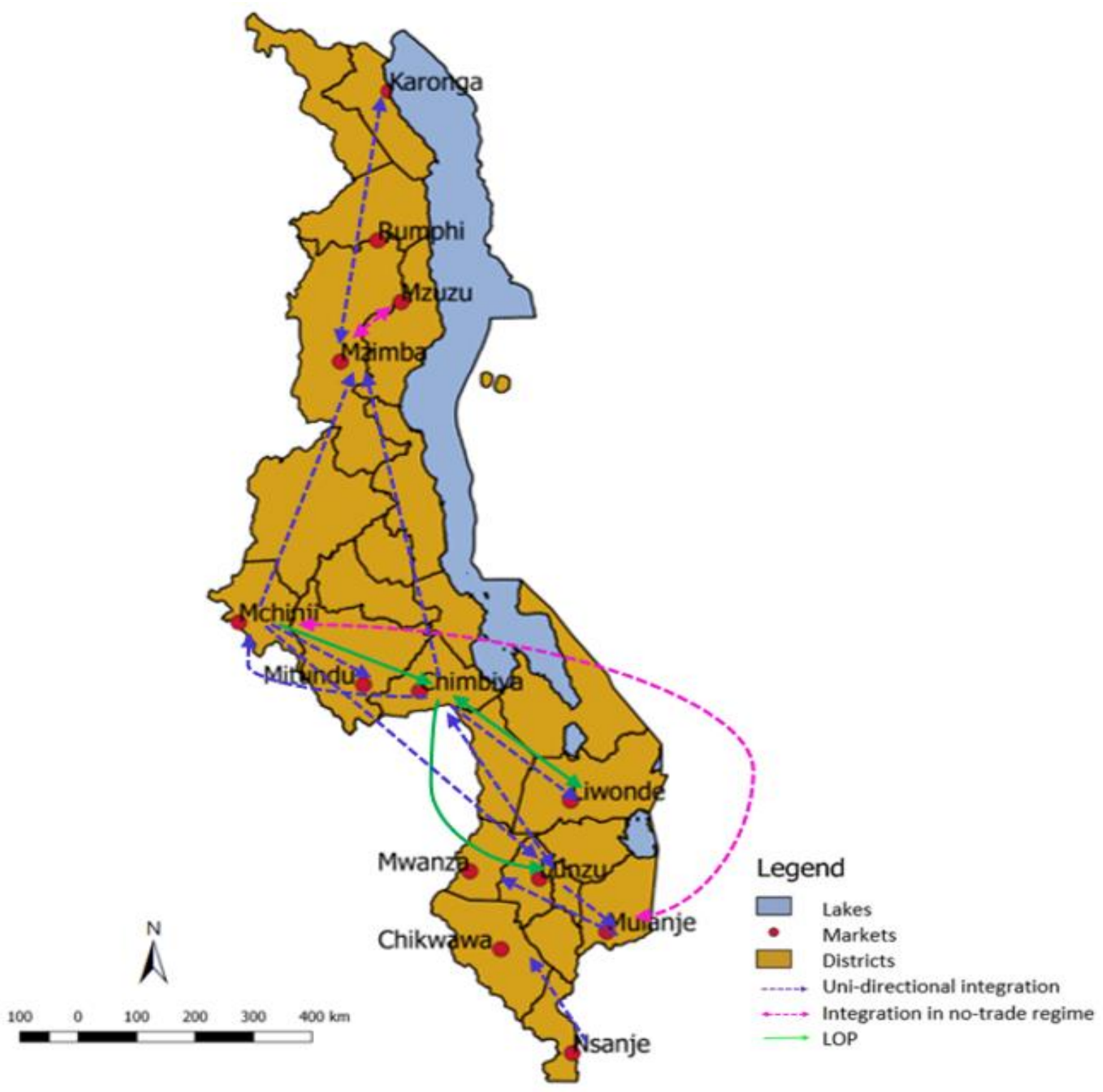

Source: Authors' construction. 
Figure A. 2: Price movements in markets integrated in all regimes, 2017-2018
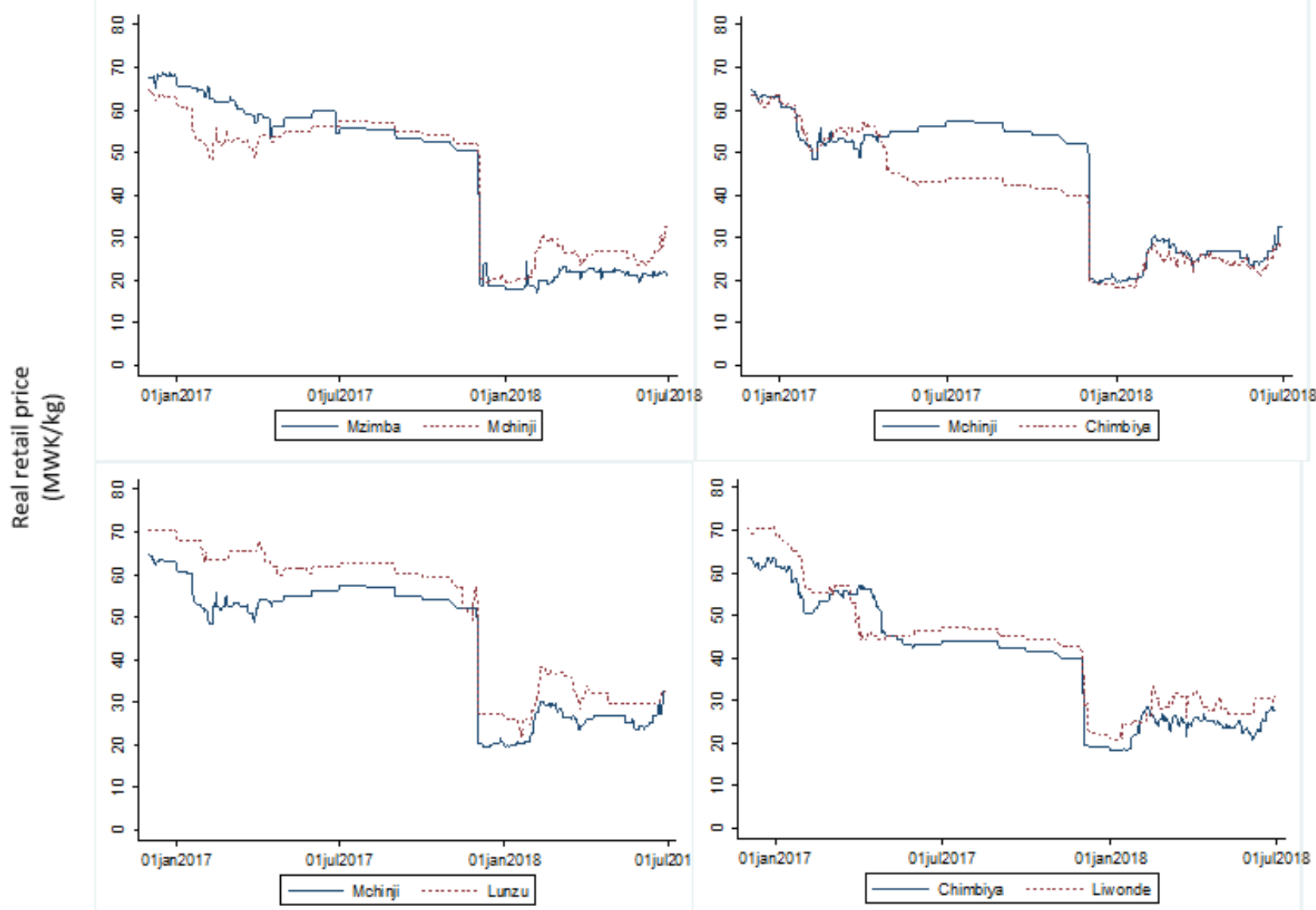
Figure A. 3: Price movements in markets integrated in at least one regime, 2017-2018
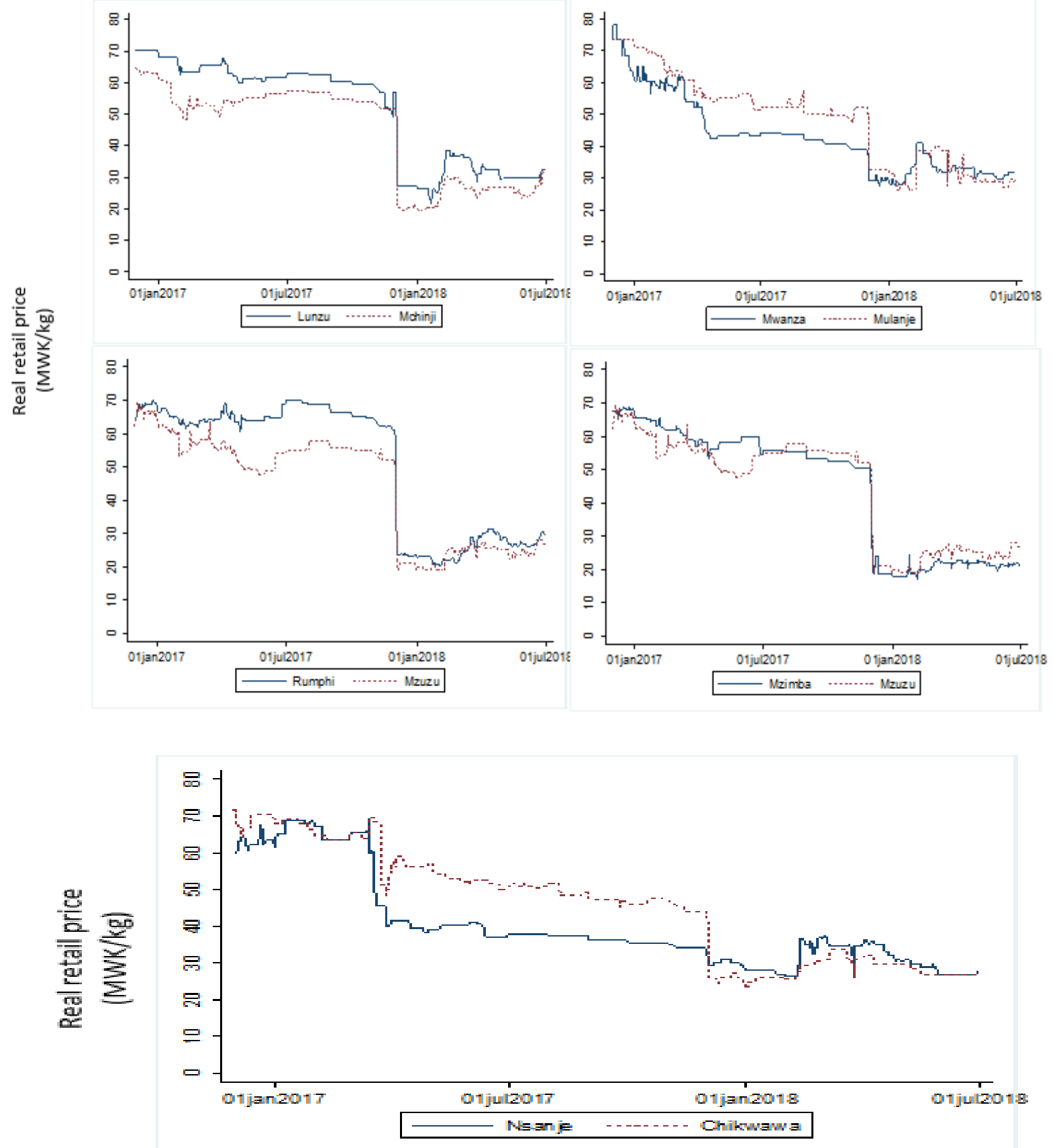
Appendix B. 1: Calculations on traders' return to storage

Given an annual interest rate is 40.34 percent.

To get a compounded monthly interest rate we use the formula:

$\left[(1+r)^{\wedge}(1 / m)\right]-1$

Where $r$ is the annual interest rate and $m$ is the number of months.

Since this is an annual interest rate, $\mathrm{m}$ is replaced by 12 . Plugging the numbers in the formula gives us:

$\left[(1+0.4034)^{\wedge}(1 / 12)\right]-1$

[1.4034^0.0833]-1

[0.02863]

Therefore,

$=2.86$ compounded interest rate

So, for an 8-month period,

$\left[(1+0.0286)^{\wedge} 8\right]-1$

[0.253]

Multiplying this by the buying price in June to get an MWK equivalence,

$=0.253 * 102=M W K 25.8$

The return on storage is therefore

$=M W K 61.5-M W K(24.33+25.80)$

$=$ MWK11.4/kg over an 8-month period 
The Malawi Strategy Support Program (MaSSP) is managed by the International Food Policy Research Institute (IFPRI) and is financially made possible by the generous support of the American people through the United States Agency for International Development (USAID) and the UK Department for International Development (DFID). This publication has been prepared as an output of MaSSP and has not been independently peer reviewed. Any opinions expressed here belong to the authors and are not necessarily representative of or endorsed by IFPRI, the US or the UK government's official policies.

\section{INTERNATIONAL FOOD POLICY RESEARCH INSTITUTE}

A world free of hunger and malnutrition

IFPRI Malawi, Area 14 Office, Plot 14/205, Lilongwe, Malawi | Mailing Address: PO Box 31666, Lilongwe 3, Malawi

T +265-1-771-780 | Email: IFPRI-Lilongwe@cgiar.org | http://massp.ifpri.info 